SAND $88-1790 \cdot \mathrm{UC}-35$

Unlimited Release

Printed September 1988

\title{
Optimized Conical Shaped Charge Design Using the SCAP Code
}

Manuel G. Vigil

Prepared by

Sandia National Laboratories

Albuquerque, New Mexico $\mathbf{8 7 1 8 5}$ and Livermore, California 94550

for the United States Department of Energy

under Contract DE-AC04-76DP00789

\section{When printing a copy of any digitized SAND Report, you are required to update the markings to current standards.}


Issued by Sandia National Laboratories, operated for the United States Department of Energy by Sandia Corporation.

NOTICE: This report was prepared as an account of work sponsored by an agency of the United States Government. Neither the United States Government nor any agency thereof, nor any of their employees, nor any of their contractors, subcontractors, or their employees, makes any warranty, express or implied, or assumes any legal liability or responsibility for the accuracy, completeness, or usefulness of any information, apparatus, product or process disclosed, or represents that its use would not infringe privately owned rights. Reference herein to any specific commercial product, process, or service by trade name, trademark, manufacturer, or otherwise, does not necessarily constitute or imply its endorsement, recommendation, or favoring by the United States Government, any agency thereof or any of their contractors or subcontractors. The views and opinions expressed herein do not necessarily state or reflect those of the United States Government, any agency thereof or any of their contractors.

Printed in the United States of America

Available from

National Technical Information Service

U.S. Department of Commerce

5285 Port Royal Road

Springfield, VA 22161

NTIS price codes

Printed copy: A05

Microfiche copy: A01 
SAND88-1790

Unlimited Release-UC35

Printed September 1988

\title{
OPTIMIZED CONICAL SHAPED CHARGE DESIGN USING THE SCAP CODE
}

\author{
Manuel G. Vigil \\ Explosive Subsystems Division \\ Sandia National Laboratories \\ Albuquerque, NM 87185-5800
}

\begin{abstract}
The Shaped Charge Analysis Program (SCAP) is used to analytically model and optimize the design of Conical Shaped Charges (CSC). A variety of existing CSCs are initially modeled with the SCAP code and the predicted jet tip velocities, jet penetrations, and optimum standoffs are compared to previously published experimental results. The CSCs vary in size from 0.69 inch $(1.75 \mathrm{~cm})$ to 9.125 inch $(23.18 \mathrm{~cm})$ conical liner inside diameter. Two liner materials (copper and steel) and several explosives (Octol, Comp B, PBX-9501) are included in the CSCs modeled. The target material was mild steel. A parametric study was conducted using the SCAP code to obtain the optimum design for a 3.86 inch $(9.8 \mathrm{~cm})$ CSC. The variables optimized in this study included the CSC apex angle, conical liner thickness, explosive height, optimum standoff, tamper/confinement thickness, and explosive width. The nondimensionalized jet penetration to diameter ratio versus the above parameters are graphically presented.
\end{abstract}

Prepared at Sandia National Laboratories, Albuquerque, New Mexico 87185 and Livermore, California 94550, for the United States Department of Energy under Contract $D E-A C 04-76 D P 00789$ 
I would like to thank A. C. Robinson for his efforts in developing the SCAP code which is a very useful aid in the design of Conical Shaped Charges. 


\section{CONTENTS}

Page

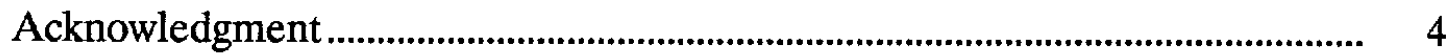

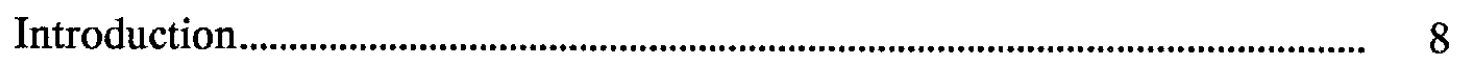

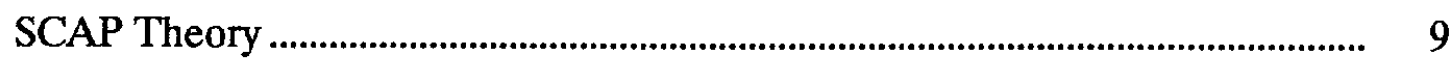

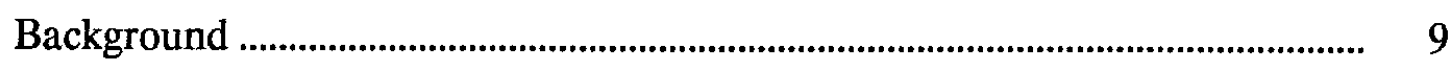

Analytical-Experimental Comparison................................................................. 10

CSC Geometrical Parametric Study ............................................................... 10

Linear Apex Angle .................................................................................... 13

Linear Thickness ........................................................................................... 13

Explosive Height ....................................................................................... 20

Tamper/Confinement Thickness......................................................................... 20

Explosive Width..................................................................................................... 20

Summary of Geometrical Parameters Study....................................................... 28

Different CSC Liner Material .................................................................... 28

Different CSC Explosives ............................................................................. 32

SCAP Code Sample Output .......................................................................... 32

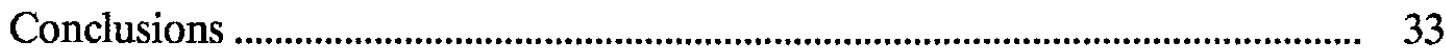

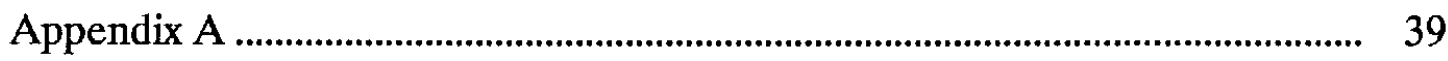

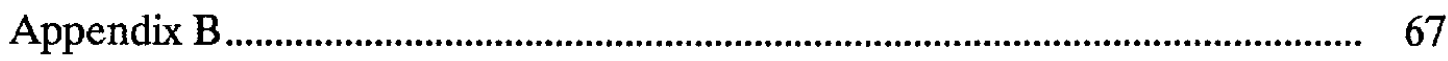

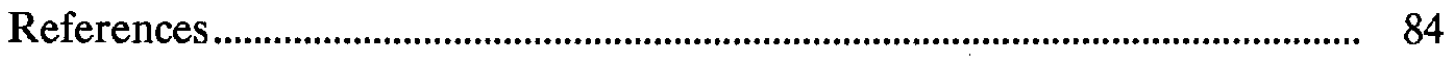




\section{FIGURES}

Figure

Page

1 General Conical Shaped Charge Cross-section .................................... 11

2 Basic Conical Shaped Charge Cross-section ........................................... 14

3 Conical Shaped Charge Jet Penetration to Diameter Ratio .................. 15

Versus Conical Liner Apex Angle and Standoff (S.O.)

4 Conical Shaped Charge Jet Penetration to Diameter ............................. 17

Ratio Versus Liner Thickness to Diameter Radio

5 Conical Shaped CHarge Jet Tip Velocity Versus.................................. 19

Liner Thickness to Diameter Ratio

6 Conical Shaped CHarge Jet Penetration to Diameter Ratio ................. 21

7 Conical Shaped Charge Jet Penetration to Diameter .............................. 23

Radio Versus Tamper Thickness to Diameter Ratio

8 Conical Shaped Charge Jet Penetration to Diameter ............................. 25

Ratio Versus Explosive Width to Diameter Ratio

9 Conical Shaped Charge Jet Tip Velocity Versus...................................... 27

Explosive Width to Diameter Ratio

10 Optimized Conical Shaped Charge Configuration.................................. 29

11 Conical Shaped Charge Jet Penetration to Diameter ........................... 30

Ratio Versus Standoff to Diameter Ratio

12 Conical Shaped Charge Jet Penetration to Diameter ............................ 35

13 Conical Shaped Charge Jet Penetration to Diameter ............................ 36

Ratio Versus Jet Tip Velocity and Explosive

14 Conical Shaped Charge Jet Penetration to Diameter

Ratio Versus Jet To Gurney Velocity and Explosive 


\section{TABLES}

Table

Page

1 Fixed SCAP Variables for CSC Geometrical Parameter Study............. 12

2 Jet Penetration Versus Standoff and Apex Angle ..................................... 16

3 CSC Jet Penetration and Liner Thickness DAta....................................... 18

4 CSC Jet Penetration and Explosive Height Data...................................... 22

5 CSC Jet Penetration and Tamper Case Thickness Data......................... 24

6 CSC Jet Penetration and Explosive Width Data ........................................ 26

7 Copper Versus Steel Liner Data .................................................................. 31

8 Conical Shaped Charge Explosive Parameters.............................................. 34

9 Conical Shaped Charge Jet Penetration Versus......................................... 38 Standoff and Explosive Data 


\section{OPTIMIZED CONICAL SHAPED CHARGE DESIGN USING THE SCAP CODE}

\section{Introduction}

The Shaped Charge Analysis Program (SCAP) ${ }^{1}$ is used to analytically model and optimize the design of Conical Shaped Charges (CSC). SCAP is an interactive modeling code developed (Robinson, 1985) at Sandia National Laboratories for the purpose of assisting in the design of conical shaped charge components. Design requirements for Sandia applications need not correspond to typical conventional shaped charge requirements. Miniaturized components, specialized materials and nonstandard designs open the way for possible unique modeling requirements. The need for an in-house Sandia code with maximum modeling flexibility and ease of use has led to the development of SCAP.

SCAP is user friendly and very inexpensive to run. It is designed for flexibility in shaped charge device configuration, choice of competing modeling techniques, and implementation of new models for various parts of conical shaped charge jet formation and penetration phenomena. The code at present contains models for liner acceleration, jet formation, jet stretching and breakup, jet penetration and confinement motion. Different models are available for some portions of the code and may be chosen via a menu format. Few a priori assumptions are built into the code with the intent that the program structure should allow the modeling of devices of nonstandard design. The code is conceptually simple and well structured.

The SCAP code was used to model some existing conical shaped charges (CSC) of various sizes and materials. The resultant analytical penetration versus standoff and jet tip velocities are compared to experimental data. The CSCs vary in size from 0.69 inch $(1.75 \mathrm{~cm})$ to 9.125 inch $(23.18 \mathrm{~cm})$ conical liner inside diameter. Copper and steel liner materials and Octol, Comp B and PBX-9501 explosives are included in the CSCs modeled. The target material was mild steel.

Additionally, a parameteric study was conducted with the code to determine the optimum design for a CSC with a copper liner. The CSC variables optimized in this study included liner apex angle, liner thickness, explosive height, tamper/confinement thickness, explosive width and standoff. For the optimized CSC design, jet penetration data are presented for the secondary explosives LX-13/XTX-8003, Comp B, Octol, PBX-9501, and RDX. The CSC jet penetration versus standoff data are presented for both copper and steel liners. 


\section{SCAP Theory}

The basic modeling theory and format for the SCAP code are described in References 1-3. The SCAP code was developed at Sandia National Laboratories ${ }^{1}$ to provide design guidance for CSC components. The SCAP code includes the following features:

1. Interactive,

2. Modeling flexibility,

3. Ease of use,

4. User friendly,

5. Analytical code,

6. Fortran 77 computer language,

7. Currently run on VAX computer,

8. Inexpensive (compared to hydro-codes),

9. Competing modeling techniques,

10. Liner acceleration modeling,

11. Jet formation modeling,

12. Jet stretching and breakup modeling,

13. Jet penetration modeling,

14. Tamping or confinement modeling

15. Menu format,

16. Hardcopy output listing and plotted output, and

17. Movie output of jet formation process using DISSPLA plotting package.

The code does not include detailed equation of state material description capability. However, the code is very useful in establishing a preliminary design of a CSC and for parametric studies. Conducting parametric studies of CSC designs with hydro-codes is not normally affordable. The current version of the code is called XSCAP20 and is an updated version of the SCAP $1.0^{1}$ version.

\section{Background}

It is assumed that the reader has some knowledge of the functioning of conical shaped charges. Chou and Flis, Reference 4, present a review of recent developments in shaped charge technology and include ninety-nine references on the theory of shaped charges. 
The relatively long high velocity metallic jet produced by the explosively collapsed conical liner is useful for many applications because of its good penetration capability. CSCs have historically found utility in many applications including oil well perforating, underwater trenching, demolition, mining work, and conventional military applications requiring the penetration of various barriers.

\section{Analytical-Experimental Comparisons}

A general cross-section with the many variables required to model a CSC are shown and defined in Figure 1. The SCAP code was used to model the CSCs with liner, explosives and tamper parameters as listed in Table AI in Appendix A. The crosssections for the CSCs listed in Table AI are shown in Figures A1-A5 in Appendix A. The SCAP input parameter data files are listed in Tables AIII - AVII. The parameters listed in Tables AIII - AVII are described and defined in Reference 1. The SCAP modeled half cross-sections (assuming symmetry) are shown in Figures A6-A10. The SCAP code jet penetration into mild steel versus standoff output are compared to experimental data in Figures A11-A15. The analytical (SCAP) data is in good agreement with the experimental data. The maximum jet penetration and optimum standoff values from Figures A11-A15 were tabulated in Table AII for the above five CSCs. The analytical-experimental values of the jet tip velocities are also listed in Table AII. The calculated and experimental jet tip velocities agree within $10 \%$.

\section{CSC Geometrical Parametric Study}

The optimal design of a CSC can become very complex because of the many geometric material variables involved as illustrated in Figure 1. Therefore, conducting a parametric study to determine the optimum value for each of the variables shown in Figure 1 is not a trivial matter. Ideally, one would like to vary one variable at a time while holding the remaining variables constant in determining the optimum value. However, the order for varying each of the variables and the fixed value for the remaining variables is not obvious.

The procedure used to obtain the results for the parametric study was to initially fix the SCAP input variables listed in Table I. Octol is a secondary explosive with relatively high metal driving ability. Copper conical liners have a reasonably high density and are very ductile, thus producing the relatively long jets necessary for 


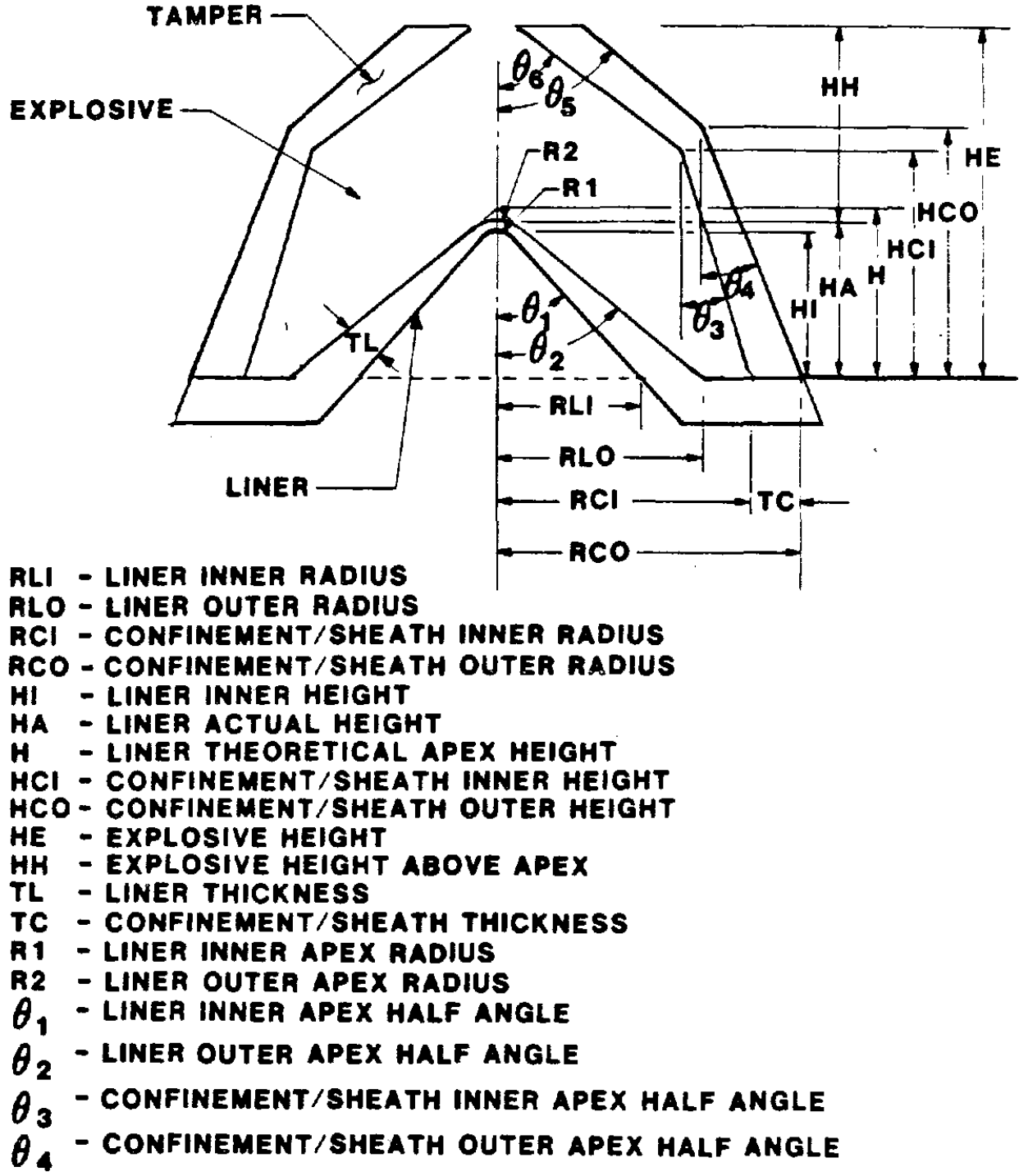

Figure 1. General Conical Shaped Charge Cross-section 
TABLE I.

Fixed SCAP Variables for CSC Geometrical Parameter Study

\section{Explosive:}

1. Octol

2. $\quad 1.81 \mathrm{~g} / \mathrm{cc}$

3. $\quad 0.848 \mathrm{~cm} / \mathrm{microsecond}$

4. Gurney Velocity $(2 \mathrm{E})^{0.5}=0.278 \mathrm{~cm} / \mathrm{microsecond}$

5. Explosive Exponent $=2.79$

\section{Conical Liner:}

1. Copper

2. Inside Cone Diameter $=9.8 \mathrm{~cm}(1 \mathrm{CD})$

3. $\quad 8.96 \mathrm{~g} / \mathrm{cc}$

4. Bulk Sound Speed $=0.394 \mathrm{~cm} / \mathrm{microsecond}$

\section{Target:}

1. Mild Steel

2. $\quad 7.86 \mathrm{~g} / \mathrm{cc}$

\section{Tamper/Explosive Confinement Casing:}

1. Aluminum

2. $\quad 2.7 \mathrm{~g} / \mathrm{cc}$

\section{SCAP Model Options (Reference 1)}

1. Units - centimeter, gram, microsecond

2. Gurney liner acceleration (A) profile (4)

3. Gurney zoning (1) - radial zones

4. Jet collapse point (IAXIS, 2) - off axis ad hoc model (YCLPS >0)

5 Interpolation type (INTER, 2) - quadratic interpolation

6. Detonation modeling (ISMDET, 1) - point detonation

7. Jet breakup modeling (IBREAK, 3) - dynamic yield stress model

8. Geometry (2) - CSC

9. Number of zones -70

10. Cutoff ratio for no jet criteria $-\mathbf{1 . 0}$

11. Dynamic yield stress for jet (copper) $-.0022 \mathrm{Mb}$

12. No. of coefficients to define liner - 4

13. IBREAK $=3$ Coefficient $-\mathbf{5 . 0}$

14. No. of confinement coefficients -8

15. Initiation point radius for $\mathrm{CSC}-0.0$

16. Total number of standoffs of interest -20

17. Number of target layers - 1

18. Target layer UMIN $-0.14 \mathrm{~cm} / \mathrm{microsecond}$ 
maximum penetration. The target and tamper/confinement are arbitrarily chosen as mild steel and aluminum, respectively. The CSC inside diameter was arbitrarily chosen as 3.86 inches $(D=C D=9.8 \mathrm{~cm})$ representing an intermediate sized CSC. Figure 2 illustrates the basic CSC cross-section configuration considered initially. The CSC parameters that were varied in this study are shown in Figure 2.

\section{Liner Apex Angle:}

Based on previous experience from experimental studies with small CSCs 5 at Sandia National Laboratories, the following initial values for explosive height $(\mathrm{H})$, liner thickness $(t)$, tamper/confinement thickness $\left(T_{c}\right)$ and explosive width $\left(W_{e}\right)$ were chosen:

$$
\begin{array}{ll}
\text { 1. } & \mathrm{H}=2 \mathrm{CD}=2 \mathrm{D} \\
\text { 2. } & \mathrm{t}=0.01 \mathrm{CD}=0.01 \mathrm{D} \\
\text { 3. } & \mathrm{T}_{\mathrm{c}}=0.02 \mathrm{CD}=0.02 \mathrm{D} \\
\text { 4. } & \mathrm{W}_{\mathrm{e}}=\text { Liner Outside Diameter }
\end{array}
$$

The liner apex angle $\beta$ was then varied between 20 and 120 degrees. The jet penetration to diameter ratio (P/D) as a function of liner apex angle (Beta) and standoff (S.O. in cone diameters) data are shown in Figure 3 and Table II. The curves for P/D versus Beta were identical for standoff (S.O.) between 4 and 6 cone diameters. Maximum P/D values then steadily decreased beyond standoffs by 6 cone diameters. The additional curves for standoffs greater than 4 cone diameters were not shown. However, for all standoffs, the optimum liner apex angle (Beta) was about 45 degrees, and this value was used for the remainder of this parametric study. Bi-conic and trumpet liner configurations ${ }^{5}$ have been shown to improve jet penetration, however, only conical liner geometries were considered in this study.

\section{Liner Thickness:}

The liner thickness $(\mathrm{t})$ was next varied between $0.25 \%$ and $5 \%$ of the cone inside diameter (D). The resultant jet penetration to diameter ratio (P/D) versus liner thickness to diameter ratio ( $t / D)$ are shown in Figure 4. The optimum liner thickness occurs at about a value of $0.01 \mathrm{D}$ or about $1 \%$ of the cone diameter. The explosive width, jet penetration, optimum standoff, and jet tip velocity data are listed in Table III. The jet tip velocity versus liner thickness is shown in Figure 5. 


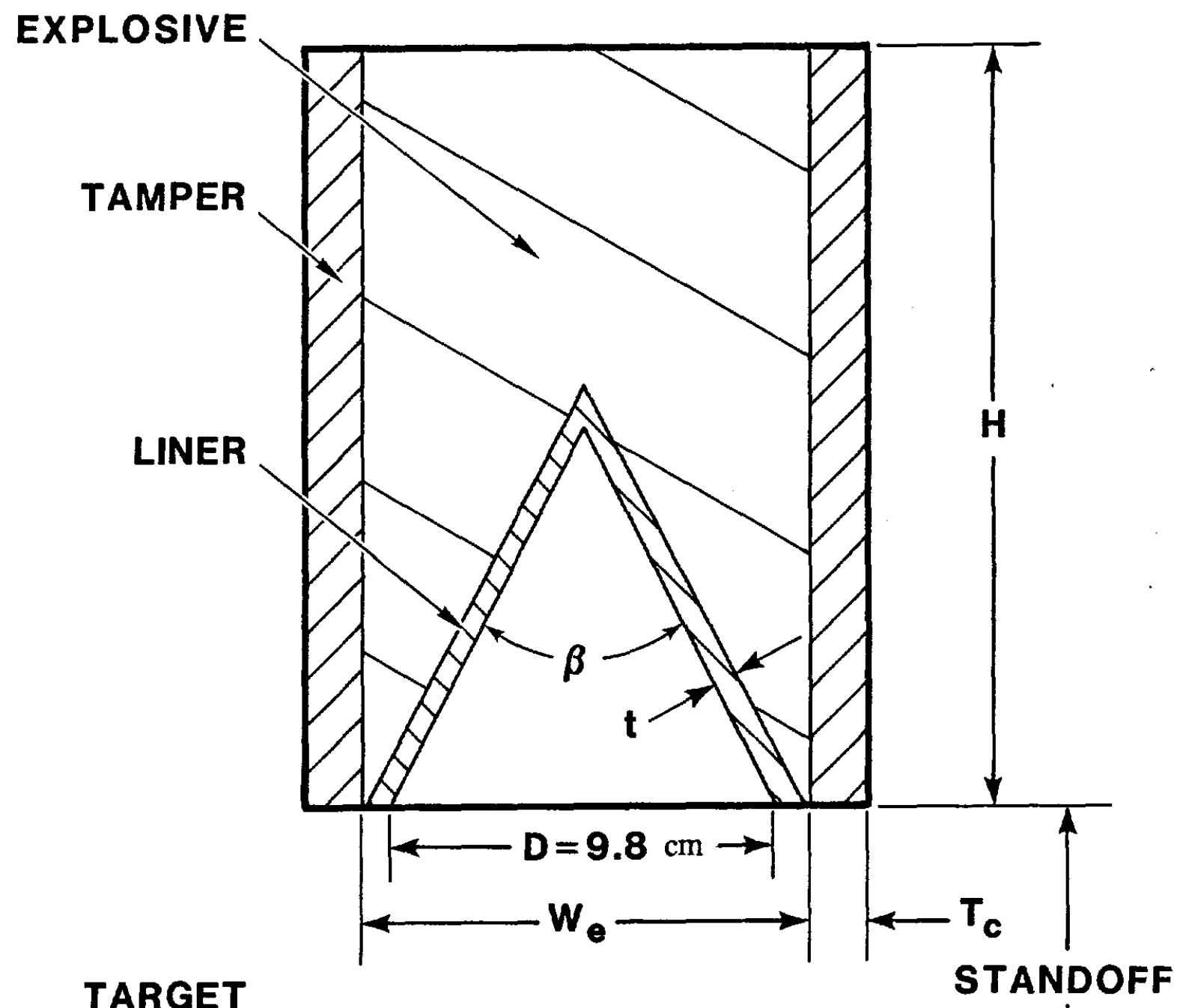

TARGET

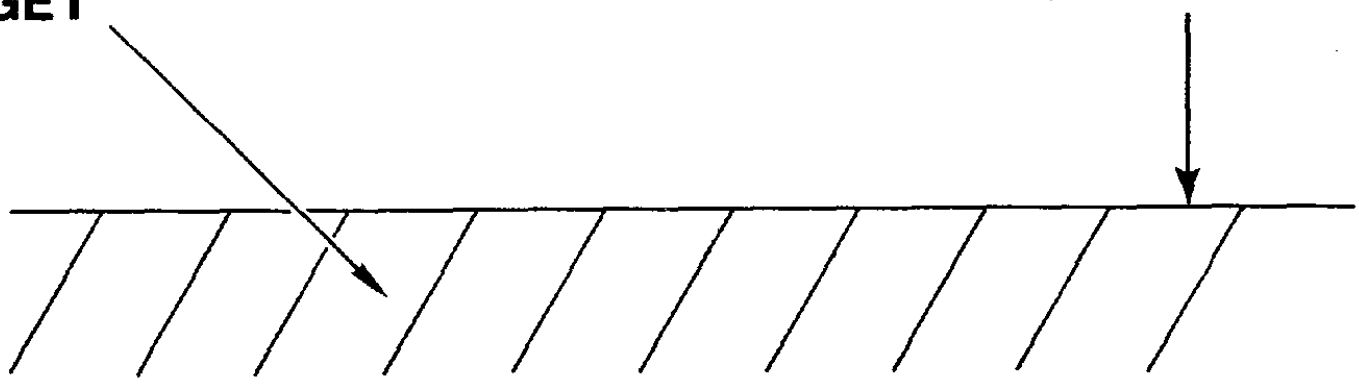

Figure 2. Basic Conical Shaped Charge Cross-section 


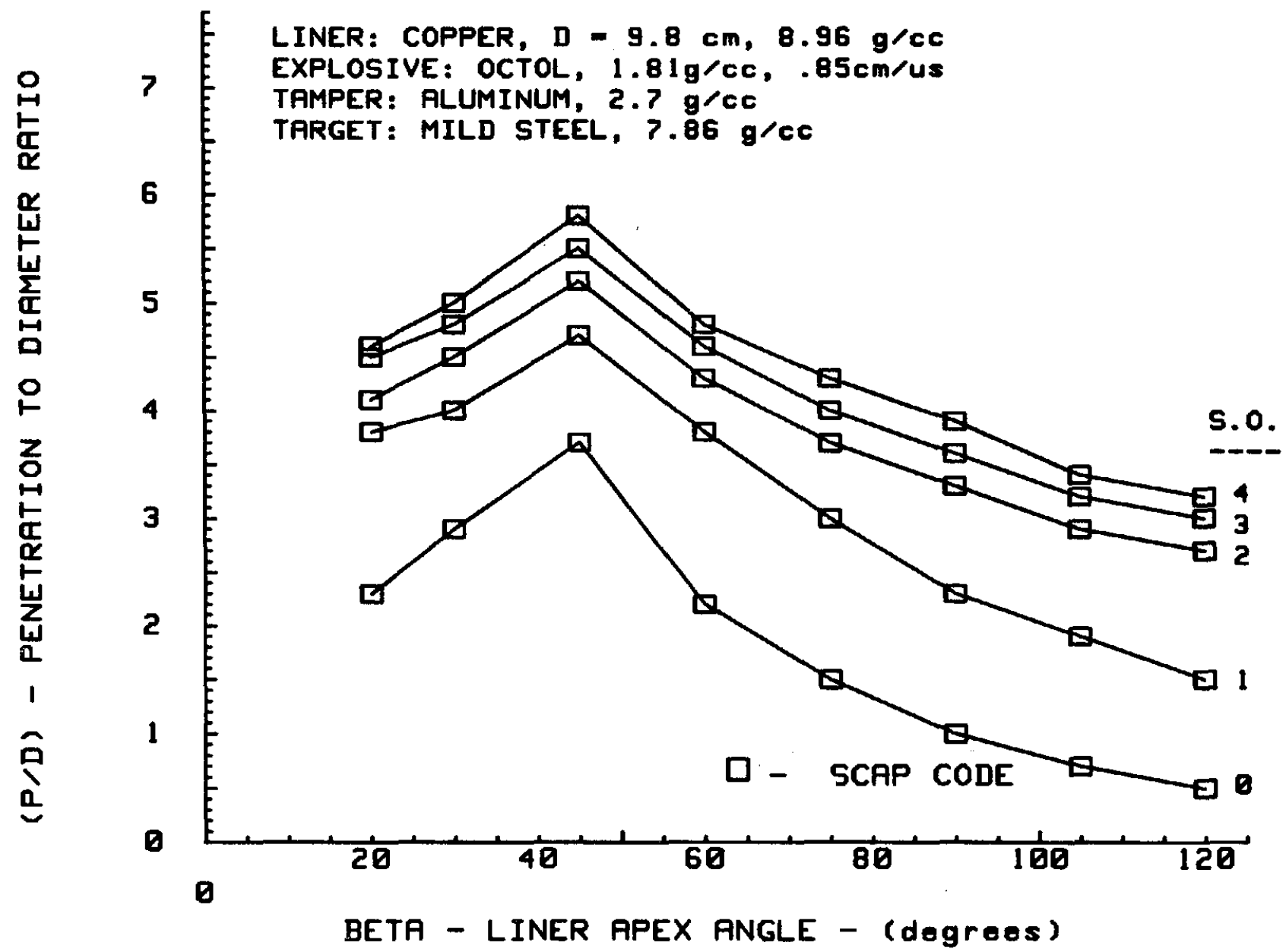

FIGURE 3. CONICAL SHAPED CHARGE JET PENETRATION TO DIAMETER RATIO VERSUS CONICAL LINER APEX ANGLE AND STANDOFF(S.0.) 
TABLE II.

\section{Jet Penetration Versus Standoff and Apex Angle}

Jet Penetration (CD)

\begin{tabular}{ccccccccc}
\hline & \multicolumn{7}{c}{ Liner Apex Angle (degrees) } \\
\cline { 2 - 8 } Standoff (CD) & 20 & 30 & 45 & 60 & 75 & 90 & 105 & 120 \\
\hline & & & & & & & & \\
0 & 2.3 & 2.9 & 3.7 & 2.2 & 1.5 & 1.0 & 0.7 & 0.5 \\
1 & 3.8 & 4.0 & 4.7 & 3.8 & 3.0 & 2.3 & 1.9 & 1.5 \\
2 & 4.1 & 4.5 & 5.2 & 4.3 & 3.7 & 3.3 & 2.9 & 2.7 \\
3 & 4.5 & 4.8 & 5.5 & 4.6 & 4.0 & 3.6 & 3.2 & 3.0 \\
4 & 4.5 & 4.9 & 5.7 & 4.7 & 4.1 & 3.6 & 3.2 & 2.9 \\
6 & 4.4 & 4.9 & 5.7 & 4.7 & 3.9 & 3.3 & 2.8 & 2.3 \\
8 & 4.0 & 4.6 & 5.5 & 4.4 & 3.5 & 2.9 & 2.2 & 1.8 \\
& & & & & & & & \\
& & & & & & & &
\end{tabular}




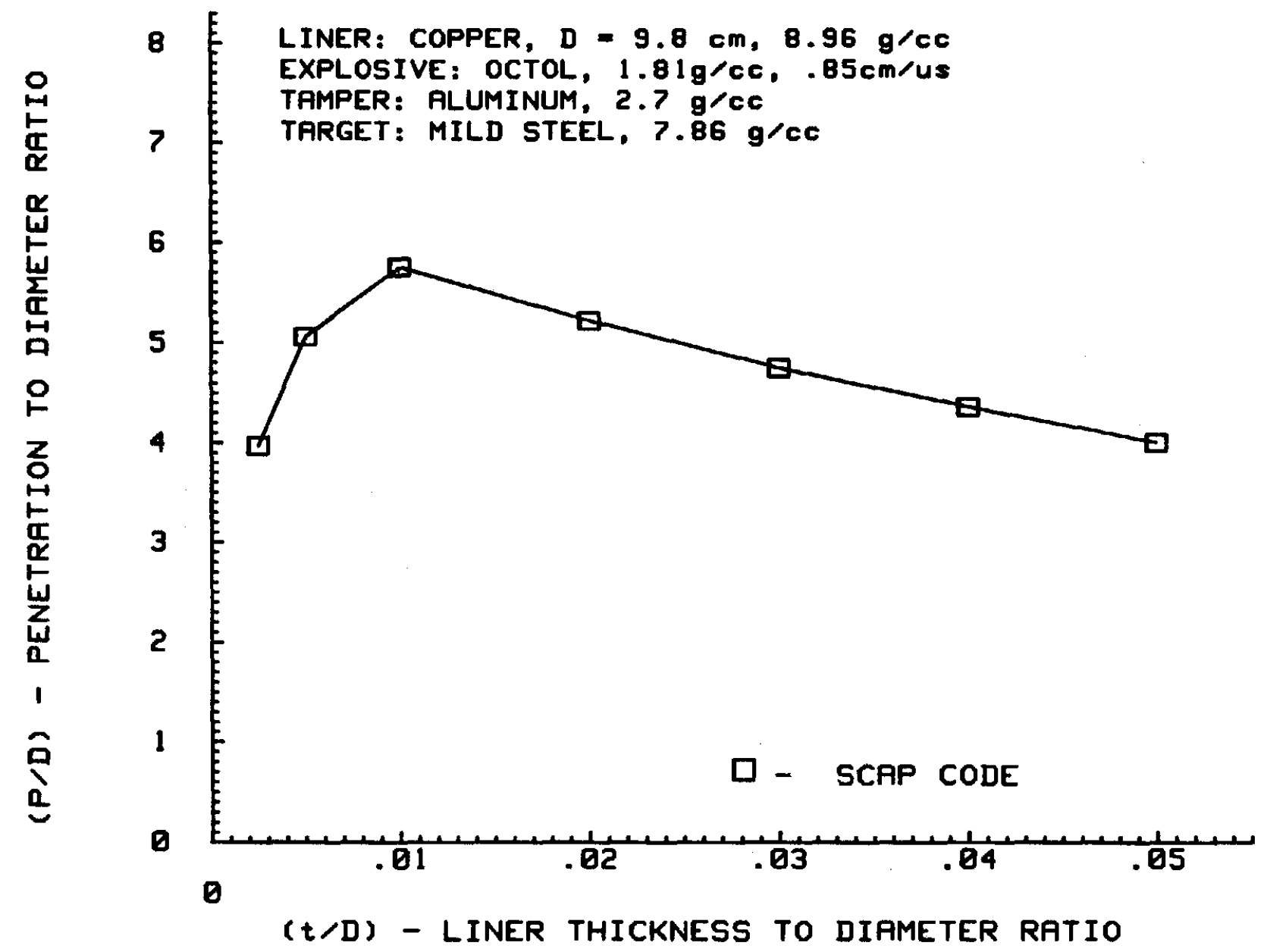

FIGURE 4. CONICAL SHAPED CHARGE JET PENETRATION TO DIAMETER RATIO VERSUS LINER THICKNESS TO DIAMETER RATIO 
TABLE III.

CSC Jet Penetration and Liner Thickness Data

CD = Cone Inside Diameter $(9.8 \mathrm{~cm})$

Optimum Standoff $=52.6 \mathrm{~cm}(8.4 \mathrm{CD})$

\begin{tabular}{|c|c|c|c|c|}
\hline \multicolumn{2}{|c|}{$\begin{array}{l}\text { LINER } \\
\text { THICKNESS }\end{array}$} & \multicolumn{2}{|c|}{$\begin{array}{c}\text { JET } \\
\text { PENETRATION }\end{array}$} & \multirow{2}{*}{$\begin{array}{l}\text { JET TIP } \\
\text { VELOCITY } \\
(\mathrm{cm} / \mu \mathrm{S})\end{array}$} \\
\hline$(\mathrm{cm})$ & $(\mathrm{CD})$ & $(\mathrm{cm})$ & $(\mathrm{CD})$ & \\
\hline .0246 & .0025 & 39.0 & 3.97 & .833 \\
\hline .0492 & .0050 & 49.7 & 5.06 & .842 \\
\hline .0980 & .0100 & 56.5 & 5.75 & .799 \\
\hline .1970 & .0200 & 51.3 & 5.22 & .675 \\
\hline .2950 & .0300 & 46.7 & 4.75 & .602 \\
\hline .3930 & .0400 & 42.9 & 4.36 & .551 \\
\hline .4920 & .0500 & 39.4 & 4.00 & .511 \\
\hline
\end{tabular}




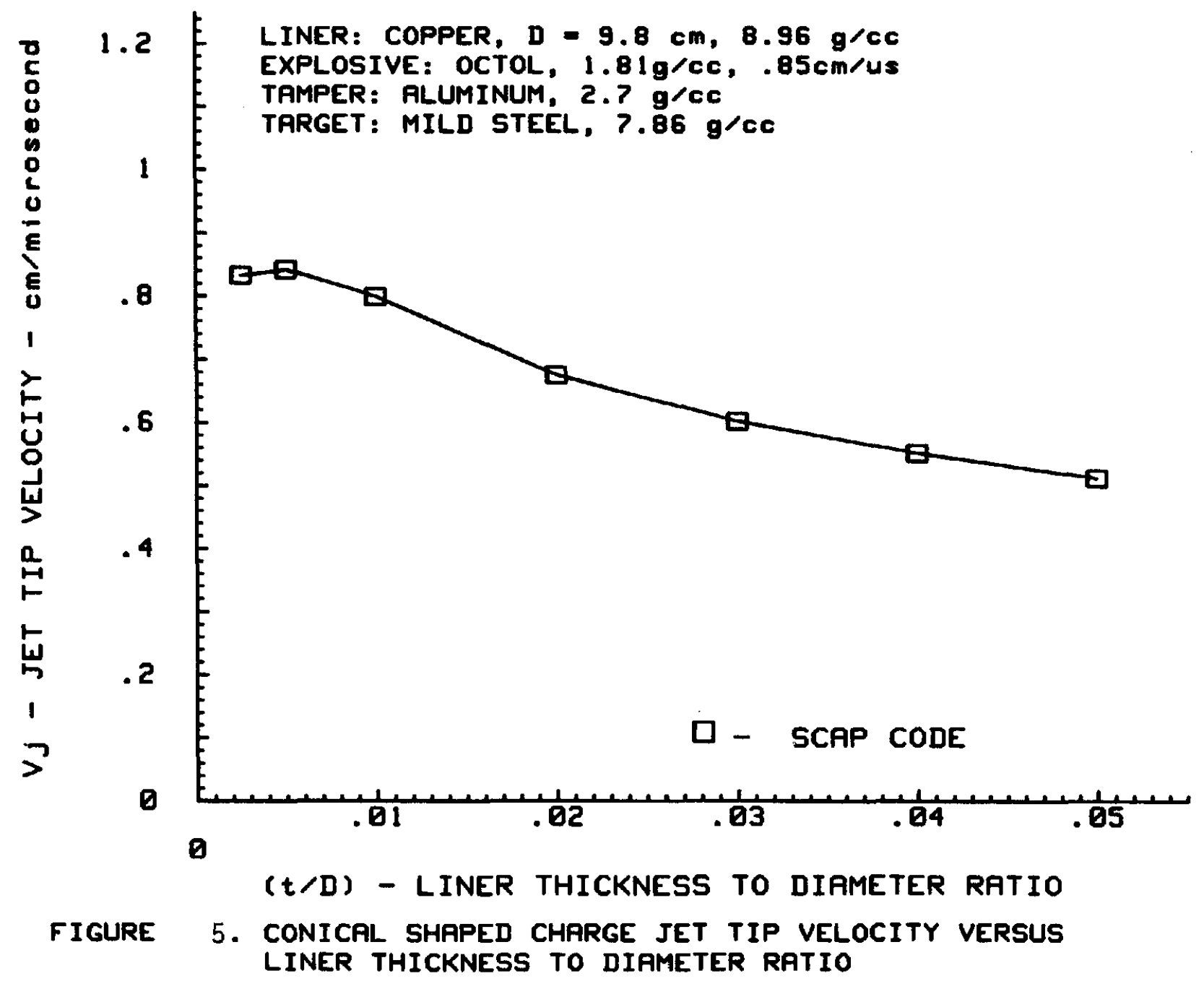




\section{Explosive Height:}

Using a liner apex angle of 45 degrees and a liner thickness of 0.01D, the explosive height $(\mathrm{H})$ was varied between $0.5 \mathrm{D}$ and $3 \mathrm{D}$. The resultant $\mathrm{P} / \mathrm{D}$ versus $\mathrm{H} / \mathrm{D}$ data are shown in Figure 6. The jet penetration increases as the explosive height increases, however, there is no significant increase in jet penetration for explosive heights greater than about 1.5D. Therefore, a value for $\mathrm{H}$ of $1.5 \mathrm{D}$ to $2 \mathrm{D}$ appears to be sufficient. The explosive height, jet penetration, and jet tip velocity are listed in Table IV. The jet tip velocity does not vary significantly with explosive height. In the SCAP code, the explosive height only effects the liner collapse angle. The smaller values of $\mathbf{H}$ result in larger collapse angles and, therefore, lower jet tip velocities.

\section{Tamper/Confinement Thickness:}

Using a liner apex angle of 45 degrees, liner thickness of 0.01D (1\%), and an explosive height of (2D), the aluminum tamper/confinement thickness $\left(T_{c}\right)$ was varied from 0 to $0.09 \mathrm{D}$. The resultant $P / D$ versus $T_{c} / D$ data are shown in Figure 7 . The jet penetration increases as the tamper thickness increases, however, there is only a $4 \%$ increase of $P / D$ for a tamper thickness increase from 0 to 0.09D. The tamper thickness and jet penetration data are listed in Table $\mathrm{V}$. The jet tip velocity did not vary significantly. The weight penalty using a very thick tamper could not be justified for the relatively small increase in $\mathrm{P} / \mathrm{D}$. A minimum rigid casing is, however, necessary to house the explosive and attach to the liner and to survive environmental requirements. Therefore, a tamper thickness of $0.02 \mathrm{D}$ was chosen.

\section{Explosive Width:}

Using a liner apex angle (Beta) of 45 degrees, liner thickness ( $t$ ) of $0.01 \mathrm{D}$, explosive height $(\mathrm{H})$ of $2 \mathrm{D}$, and a tamper thickness $\left(\mathrm{T}_{\mathrm{c}}\right)$ of $0.02 \mathrm{D}$, the explosive width $\left(W_{e}\right)$ was varied from $1.05 \mathrm{D}$ to $1.41 \mathrm{D}$. The resultant $\mathrm{P} / \mathrm{D}$ versus $\mathrm{W}_{\mathrm{e}} / \mathrm{D}$ data are shown in Figure 8. The $P / D$ values increase significantly (38\%) from 5.8 to 8 for $W_{e} / D$ values from 1.05D to 1.41D, respectively. Therefore, the value of $\mathrm{W}_{\mathrm{e}}$ selected will be more dependant on explosive and total component weight and shock-shrapnel constraints. The explosive width, jet penetration, optimum standoff and jet tip velocity values are listed in Table VI. The jet tip velocity $\left(\mathrm{V}_{\mathrm{j}}\right)$ versus explosive width to diameter ratio $\left(\mathrm{W}_{\mathrm{e}} / \mathrm{D}\right)$ data are shown in Figure 9. For values of $\left(\mathrm{W}_{\mathrm{e}} / \mathrm{D}\right)>1$, significant forward explosive detonation gas product venting could occur which might degrade the performance of Gurney modeling. Therefore, the significant gain in penetration for larger $\mathrm{W}_{\mathrm{e}} / \mathrm{D}$ values may not be realized. 


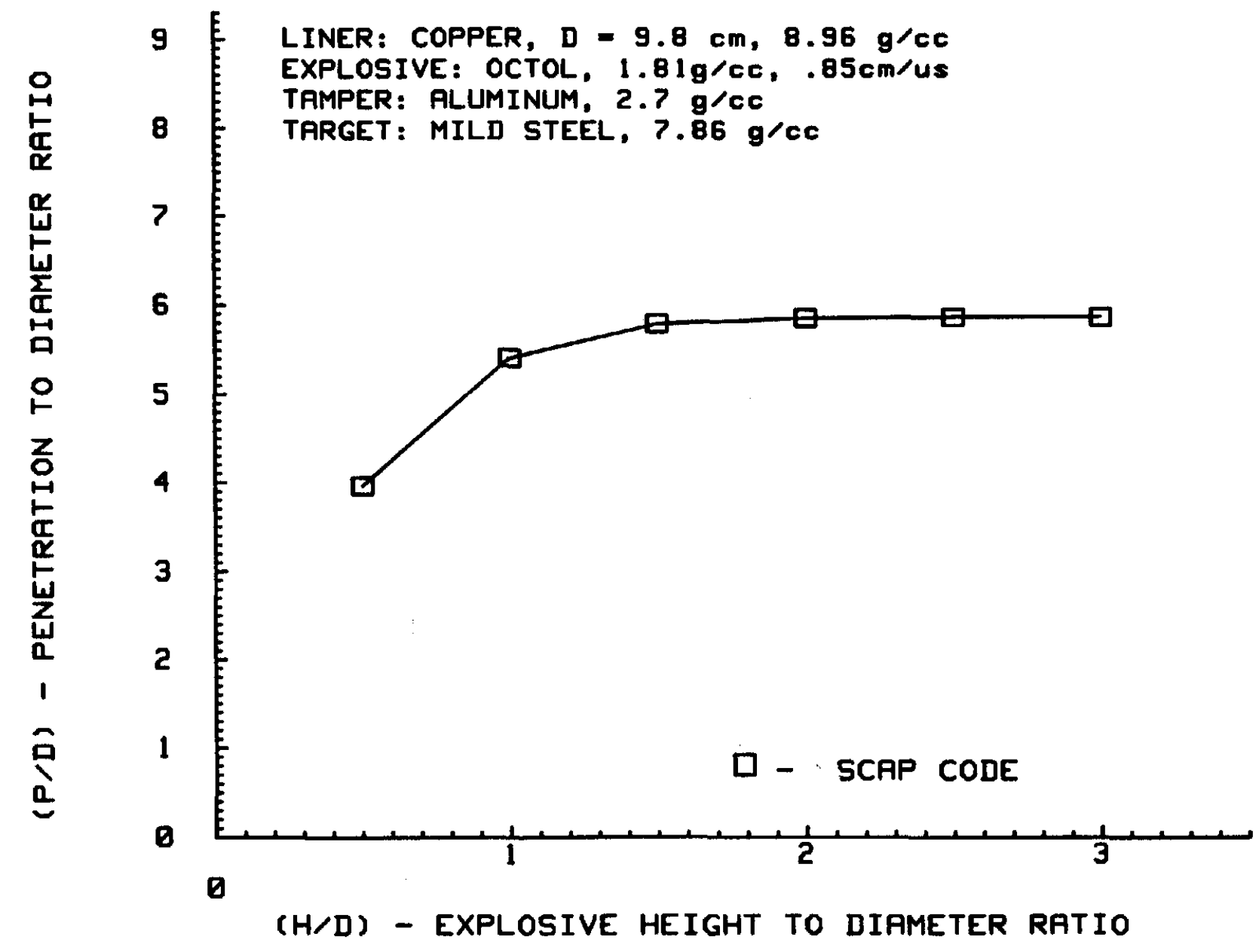
VERSUS EXPLOSIVE HEIGHT TO DIAMETER RATIO 


\section{TABLE IV.}

CSC Jet Penetration and Explosive Height Data

$\mathrm{CD}=$ Cone Inside Diameter $(9.8 \mathrm{~cm})$

Optimum Standoff $=52.6 \mathrm{~cm}(8.4 \mathrm{CD})$

\begin{tabular}{|c|c|c|c|c|}
\hline \multicolumn{2}{|c|}{$\begin{array}{l}\text { EXPLOSIVE } \\
\text { HEIGHT }\end{array}$} & \multicolumn{2}{|c|}{$\begin{array}{l}\text { JET } \\
\text { PENETRATION }\end{array}$} & \multirow{2}{*}{$\begin{array}{l}\text { JET TIP } \\
\text { VELOCITY } \\
(\mathrm{cm} / \mu \mathrm{S})\end{array}$} \\
\hline$(\mathrm{cm})$ & $\overline{(\mathrm{CD})}$ & $(\mathrm{cm})$ & (CD) & \\
\hline 4.9 & 0.5 & 38.9 & 3.96 & .777 \\
\hline 9.8 & 1.0 & 53.2 & 5.41 & .831 \\
\hline 14.7 & 1.5 & 56.9 & 5.79 & .832 \\
\hline 19.6 & 2.0 & 57.5 & 5.85 & .832 \\
\hline 26.5 & 2.5 & 57.6 & 5.86 & .840 \\
\hline 29.4 & 3.0 & 57.6 & 5.86 & .843 \\
\hline 49.0 & 5.0 & 57.0 & 5.80 & .845 \\
\hline
\end{tabular}




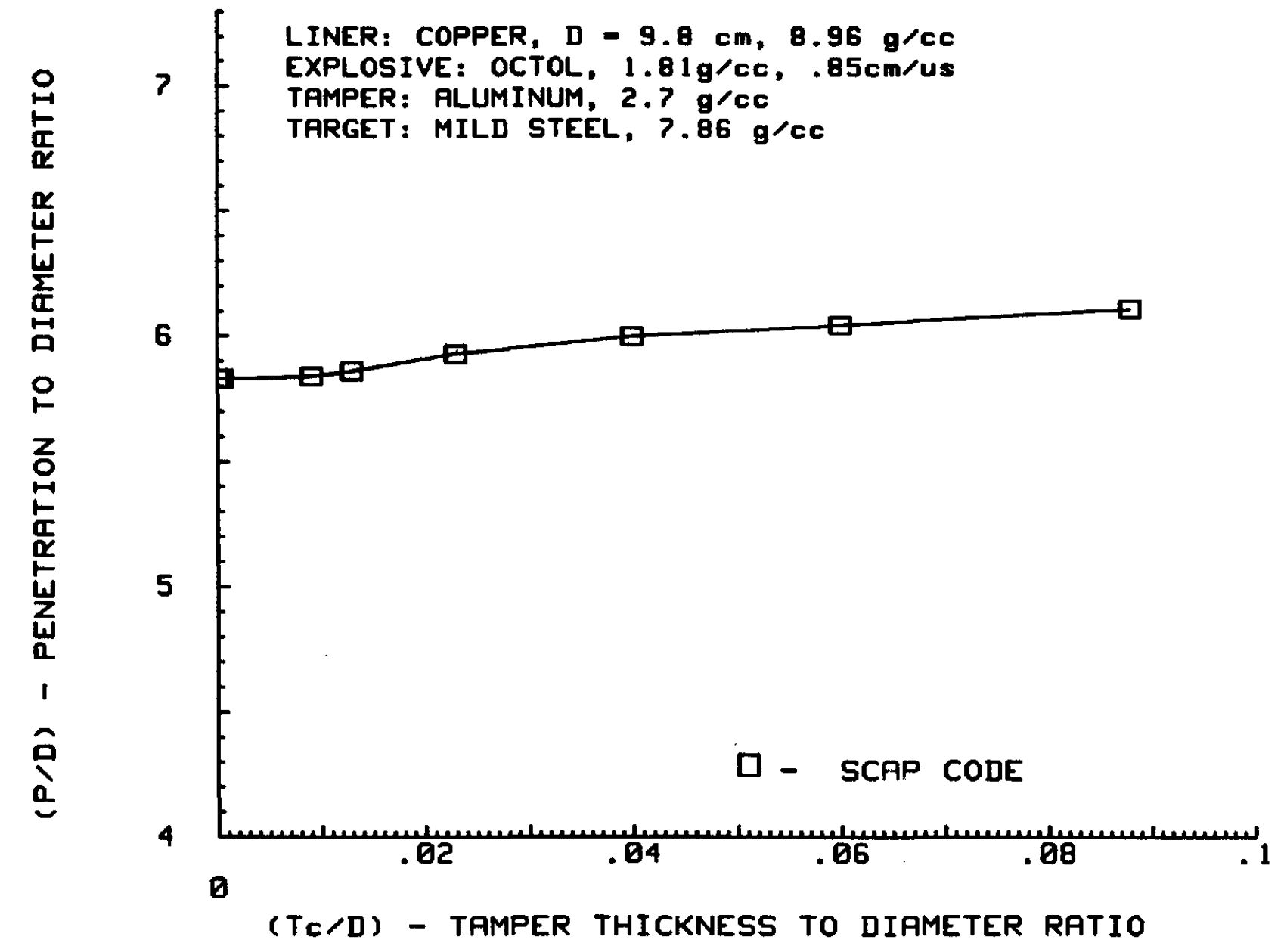

FIGURE 7. CONICAL SHAPED CHARGE JET PENETRATION TO DIAMETER RATIO VERSUS TAMPER THICKNESS TO DIAMETER RATIO 
TABLE V.

CSC Jet Penetration and Tamper Case Thickness Data

Explosive length $=2 \mathrm{CD}=19.66 \mathrm{~cm}$,

$\mathrm{CD}=$ Cone Inside Diameter $(9.8 \mathrm{~cm})$

Jet Tip Velocity $=(0.837-0.844 \mathrm{~cm} /$ microsecond $)$

\begin{tabular}{|c|c|c|c|}
\hline \multicolumn{2}{|c|}{$\begin{array}{l}\text { Tamper } \\
\text { Thick }\end{array}$} & \multicolumn{2}{|c|}{$\begin{array}{c}\text { Jet } \\
\text { Penetration }\end{array}$} \\
\hline$(\mathrm{cm})$ & (CD) & $(\mathrm{cm})$ & (CD) \\
\hline .0005 & .00005 & 57.3 & 5.83 \\
\hline .0050 & .00050 & 57.4 & 5.83 \\
\hline .0898 & .00910 & 57.6 & 5.84 \\
\hline .1290 & .01300 & 57.4 & 5.86 \\
\hline .2230 & .02300 & 58.3 & 5.93 \\
\hline .8680 & .08800 & 60.1 & 6.11 \\
\hline
\end{tabular}




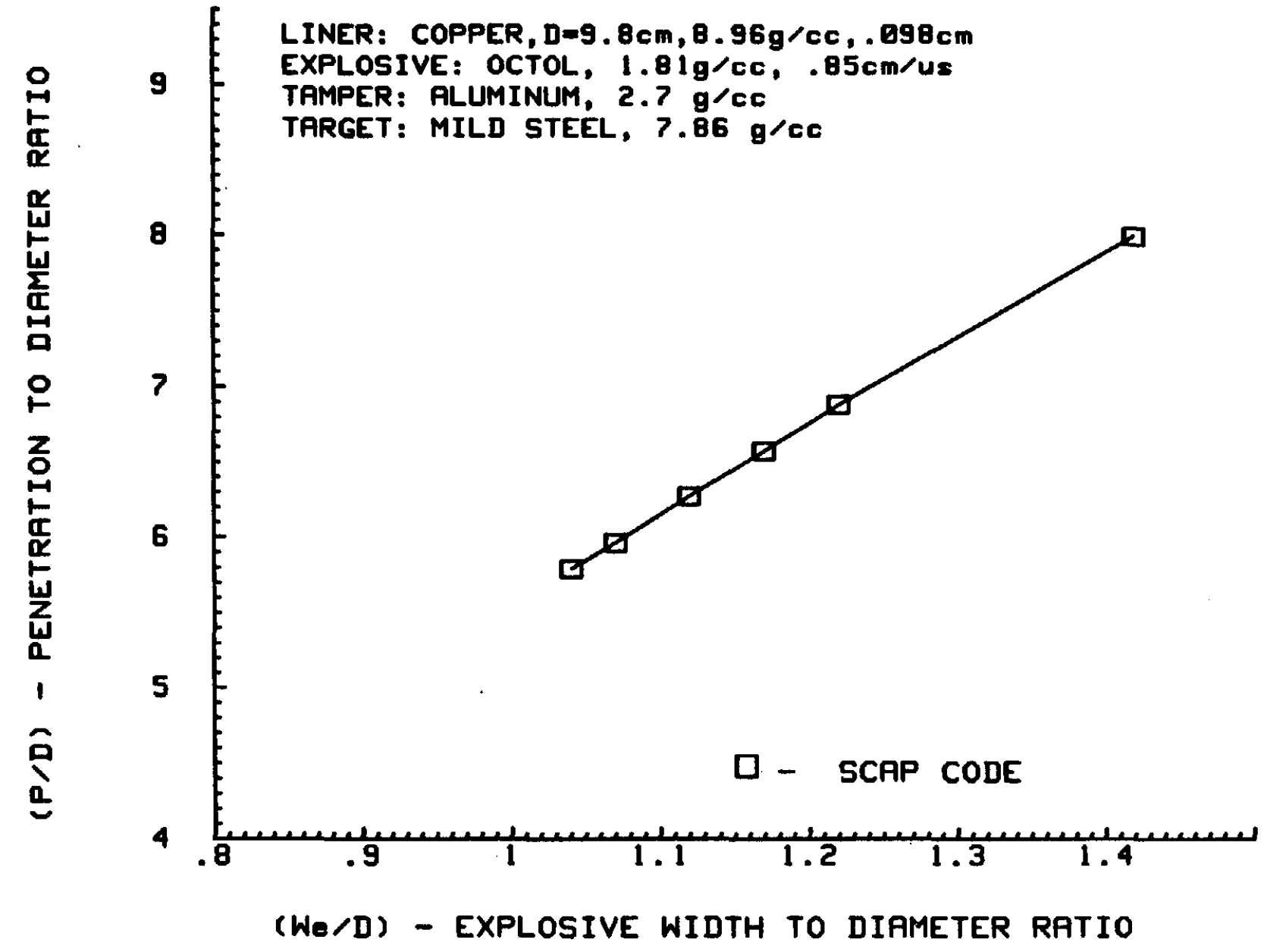

FIGURE 8. CONICAL SHAPED CHARGE JET PENETRATION TO DIAMETER RATIO VERSUS EXPLOSIVE WIDTH TO DIAMETER RATIO 
TABLE VI.

CSC Jet Penetration and Explosive Width Data CD = Cone Inside Diameter $(9.8 \mathrm{~cm})$

\begin{tabular}{|c|c|c|c|}
\hline EXPLOSIVE & JET & OPTIMUM & JET TIP \\
\hline HEIGHT & PENETRATION & STANDOFF & VELOCITY \\
\hline$(\mathrm{cm}) \quad(\mathrm{CD})$ & $(\mathrm{cm}) \quad(\mathrm{CD})$ & $(\mathrm{cm}) \quad(\mathrm{cd})$ & $(\mathrm{cm} / \mu \mathrm{S})$ \\
\hline
\end{tabular}

$\begin{array}{ccccccc}10.2 & 1.04 & 56.9 & 5.79 & 52.6 & 5.35 & 0.805 \\ 10.5 & 1.07 & 58.6 & 5.96 & 52.6 & 5.35 & 0.810 \\ 11.0 & 1.12 & 61.6 & 6.27 & 63.2 & 6.43 & 0.818 \\ 11.5 & 1.17 & 64.6 & 6.57 & 63.2 & 6.43 & 0.826 \\ 12.0 & 1.22 & 67.6 & 6.88 & 63.2 & 6.43 & 0.833 \\ 14.0 & 1.42 & 75.8 & 7.99 & 105.0 & 10.6 & 0.855\end{array}$




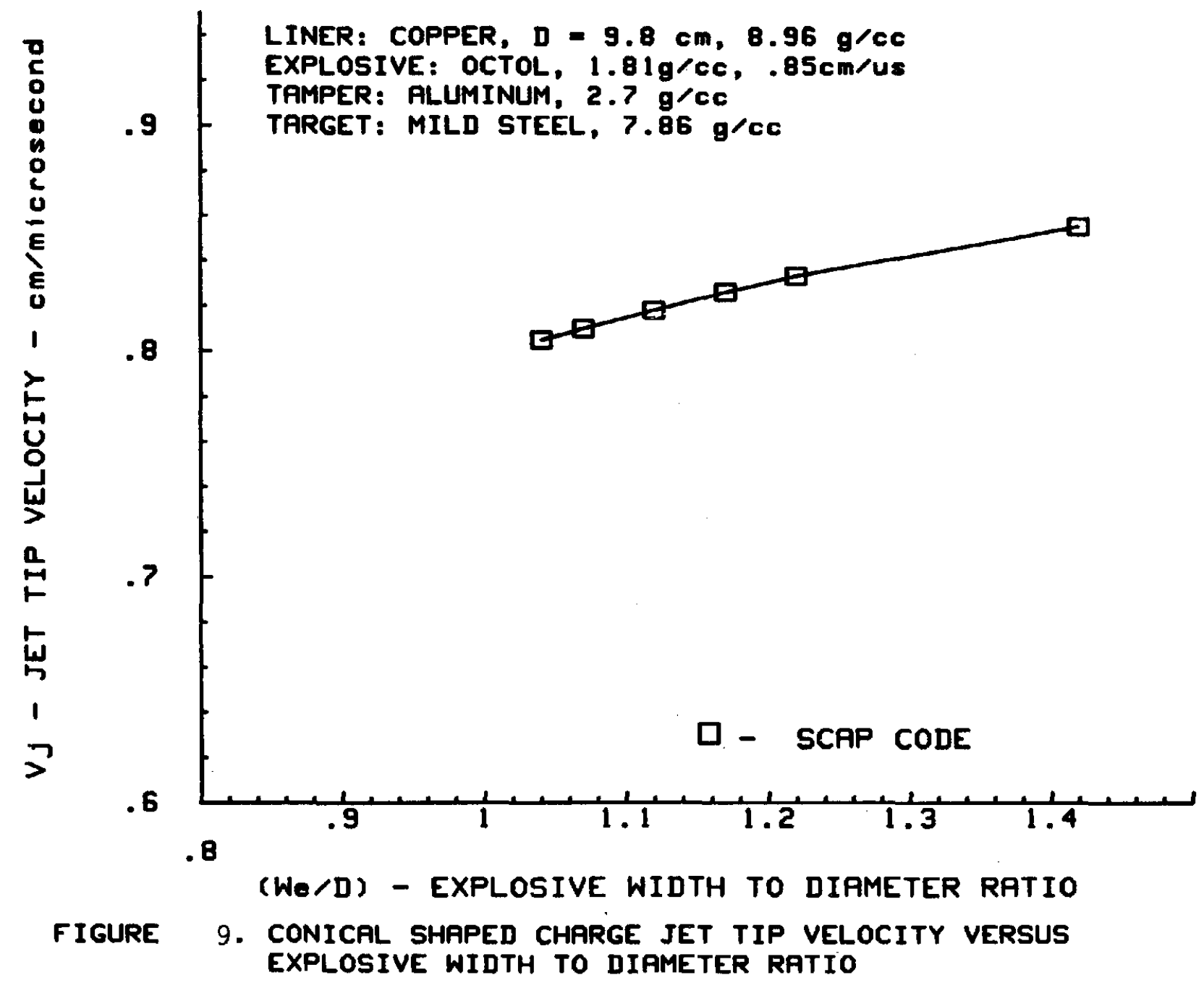




\section{Summary of Geometrical Parameters Study}

The geometrically optimized CSC for the fixed parameters listed in Table I should be configured as shown in Figure 10. The 1.21D vertical height for the tamper and 22.5 degree upper taper of the tamper were found to be near optimum if a centered single point detonation of the explosive is assumed.

Using a copper liner, a secondary explosive with properties similar to Octol, and an aluminum (or some equivalent weight and thickness of a different material) tamper, the optimized configuration shown in Figure 10 can be scaled to any diameter CSC desired to obtain scaled penetrations into mild steel targets. Dimensional analysis and similarity methods ${ }^{6-11}$ have been used to derive scaling laws that are commonly accepted and have been verified experimentally.

\section{Different CSC Liner Materials}

The optimized CSC configuration shown in Figure 10 was used to briefly investigate the effect of liner material. The CSC cone diameter was fixed at 3.86 inch $(9.8 \mathrm{~cm})$. Copper and steel liners were evaluated. The jet penetration to diameter ratio $(\mathrm{P} / \mathrm{D})$ versus standoff to diameter ratio are compared for copper and steel liners in Figure 11. Density, bulk sound speed, maximum jet penetration, optimum standoff, and jet tip velocity are compared for copper and steel liners in Table VII. Larger liner densities relative to the target density have been demonstrated ${ }^{1}$ to produce greater jet penetrations for equal jet tip velocities and jet lengths. However, the higher liner densities usually result in larger liner mass to explosive ratios and, therefore, lower conical liner collapse velocities which produce lower jet tip velocities and potentially less penetration.

Since only a relatively small percentage of the liner thickness forms the high velocity penetrating jet, ${ }^{5}$ high density material (platinum, gold, etc.) plating of low density (aluminum for example) material would be very desirable. ${ }^{3}$ This would produce a multi-layered liner ${ }^{3}$ which would be much more efficient for a given CSC configuration. However, the cost of materials and liner forming processes usually prohibit the use of multi-layered liners. The use of single layered liners of depleted uranium and tantalum has been shown to be very effective. More dense liners than copper or steel were not evaluated because a good estimate of the minimum jet penetration velocities for those materials in steel or other targets were not available. The XSCAP20 code is currently being improved to include jet-target yield strength models that will not require the minimum jet penetration velocity as input. 


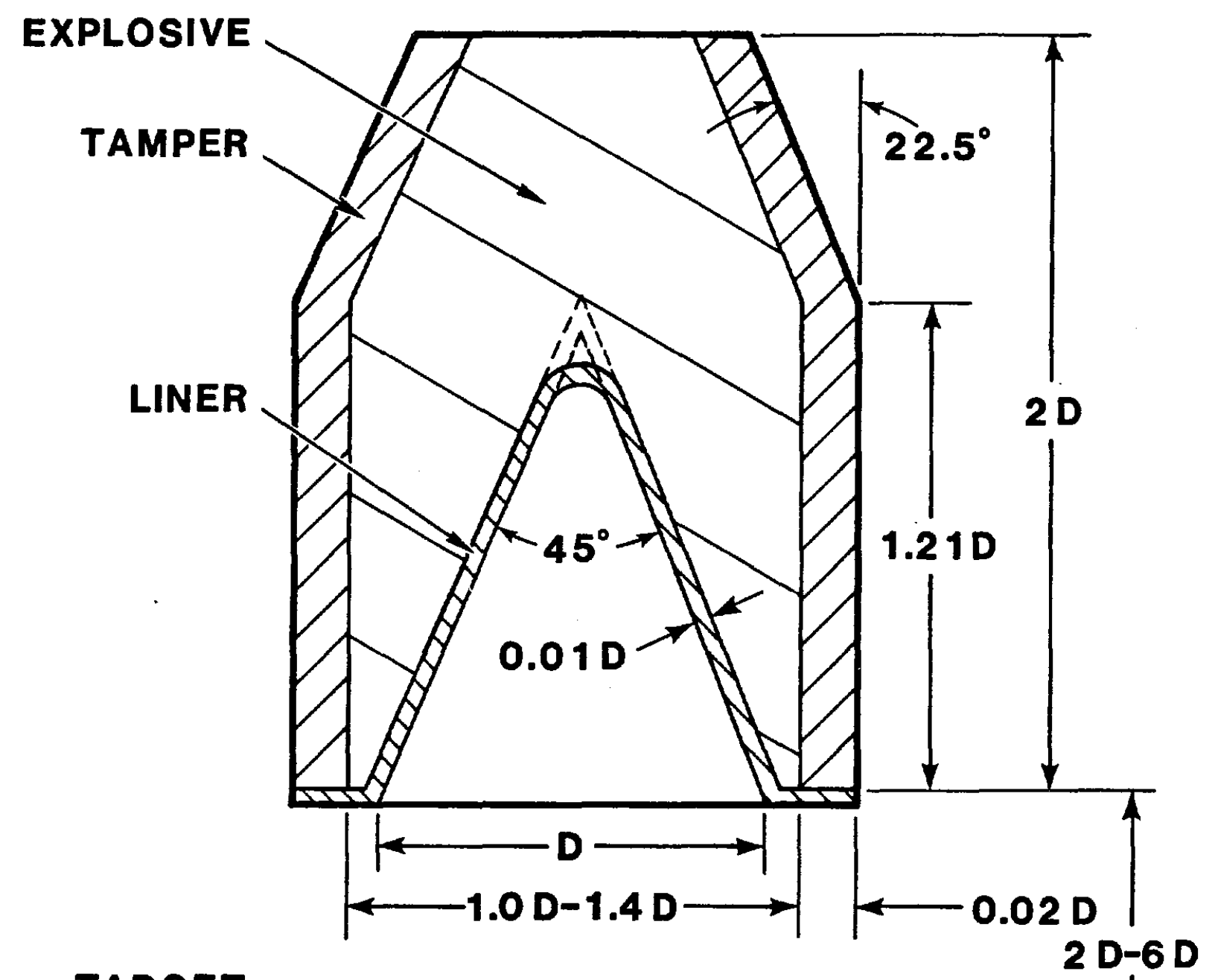

TARGET

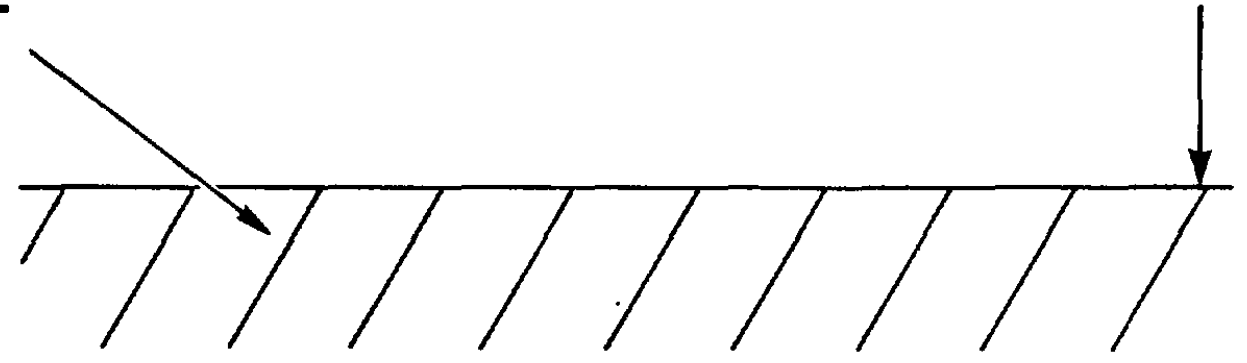

Figure 10. Optimized Conlcal Shaped Charge Configuration 


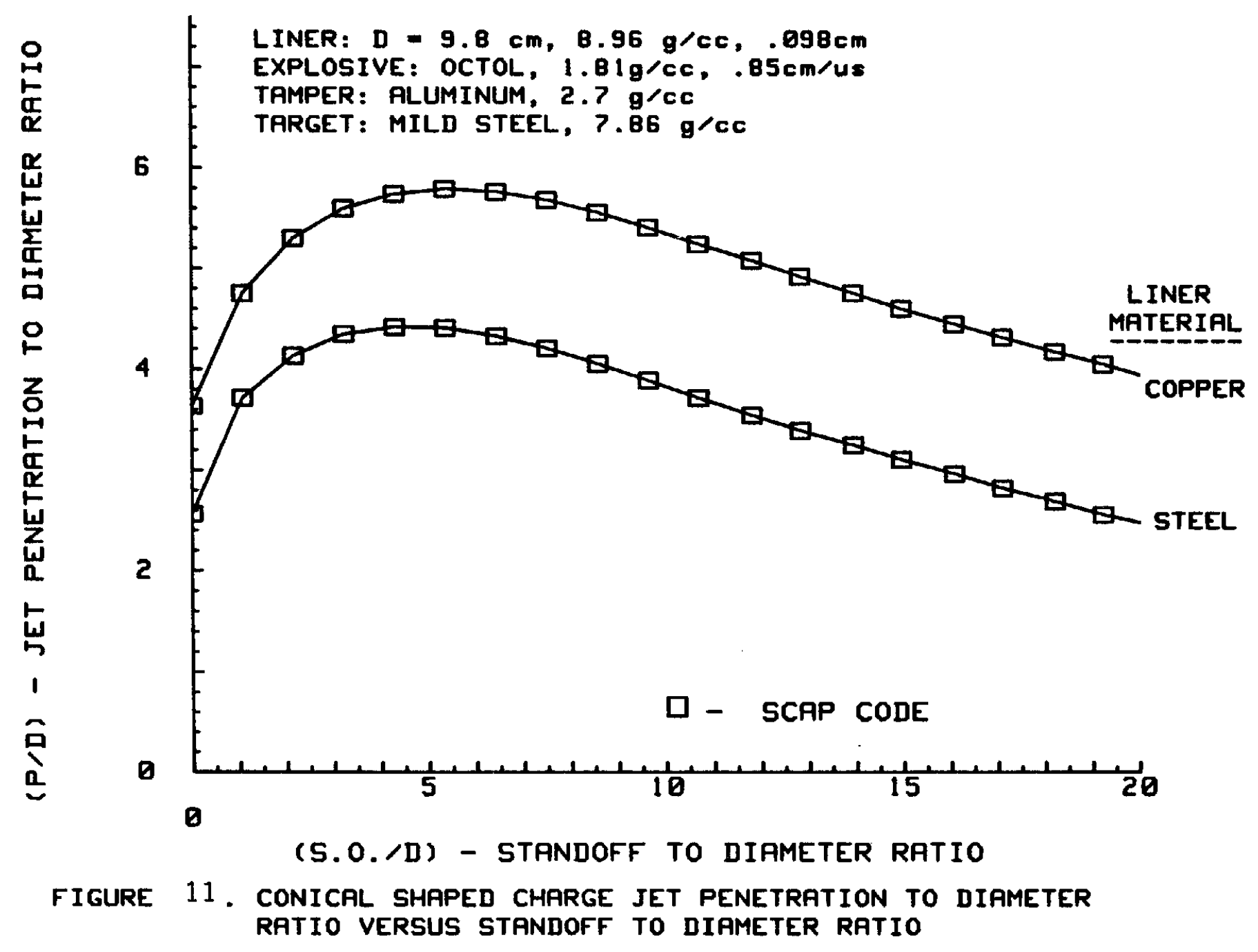


TABLE VII.

Copper Versus Steel Liner Data

$C D=D=9.8 \mathrm{~cm}$, Octol Explosive, Aluminum Tamper

Configuration - Figure 10

\begin{tabular}{|c|c|c|c|c|c|c|c|c|c|}
\hline \multirow[b]{2}{*}{$\begin{array}{l}\text { Liner } \\
\text { Material }\end{array}$} & \multirow[b]{2}{*}{$\begin{array}{l}\text { Density } \\
(\mathrm{g} / \mathrm{CC})\end{array}$} & \multirow{2}{*}{$\begin{array}{l}\text { Bulk } \\
\text { Sound } \\
\text { Speed } \\
(\mathrm{cm} / \mu \mathrm{S})\end{array}$} & \multirow{2}{*}{$\begin{array}{c}\text { Max Jet } \\
\text { Penetration } \\
\text { (cm) (CD) }\end{array}$} & \multirow{2}{*}{\multicolumn{2}{|c|}{$\begin{array}{l}\text { Optimum } \\
\text { Standoff }\end{array}$}} & \multirow{2}{*}{$\begin{array}{c}\text { Jet Tip } \\
\text { Velocity } \\
(\mathrm{cm} / \mu \mathrm{S})\end{array}$} & \multicolumn{3}{|c|}{ SCAP Variables } \\
\hline & & & & & & & TBCON & YLIN & $\begin{array}{l}\mathrm{UMIN} \\
(\mathrm{cm} / \mu \mathrm{S})\end{array}$ \\
\hline Copper & 8.96 & 0.394 & 56.8 & 52.6 & 5.4 & 0.805 & 5 & .0022 & .14 \\
\hline Steel & 7.86 & 0.456 & 43.1 & 42.5 & 4.3 & 0.826 & 7 & .0079 & .14 \\
\hline
\end{tabular}

TBCON - Jet breakup - yield stress model constant

YLIN - Dynamic yield stress of jet material

UMIN - Minimum jet penetration velocity 


\section{Different CSC Explosives}

The explosives listed in Table VIII were modeled in the CSC configuration shown in Figure 10. The SCAP input parameters required are also listed in Table VIII. The jet penetration to diameter ratio (P/D) versus Gurney Velocity ${ }^{12}$ (explosive ability to drive metal) data are shown in Figure 12 for the different explosives listed in Table VIII. Clearly, the higher the Gurney velocity, the larger the jet penetration. The P/D versus jet tip velocity $\left(V_{j}\right)$ data are shown in Figure 13 for the same explosives. Again, the higher the jet tip velocity the larger the jet penetration. The $P / D$ versus jet tip to Gurney velocity ratio $\left(\mathrm{V}_{\mathrm{j}} / \mathrm{V}_{\mathrm{g}}\right)$ are illustrated in Figure 14. The higher $\left(\mathrm{V}_{\mathrm{j}} / \mathrm{V}_{\mathrm{g}}\right)$ ratios produce the larger jet penetration.

\section{SCAP Code Sample Output}

A sample graphic output for the 3.86 inch $(9.8 \mathrm{~cm})$ diameter CSC is included in Appendix B. The initial cross-section modeled in SCAP code is illustrated in Figure B1. Tamper and liner material velocities versus initial material position are shown in Figures B2 and B3. The accumulated jet mass, momentum, kinetic energy and breakup time versus jet velocity are shown in Figures B4 - B7. Jet penetration versus time and velocity are shown in Figures B8 - B12 for standoffs of 0,21.1, 63.2, 105, and $189 \mathrm{~cm}$, respectively. The detonation wave propagation, conical liner collapse, jet and slug formation, and tamper-explosive detonation product gas expansion are graphically illustrated in Figures B13 - B16. A description of some of the CSC/jet parameter data found in Appendix B is presented in Reference 1. Several graphs are new and have never been documented. 


\section{Conclusions}

The SCAP code has been shown to be a useful tool in the design of conical shaped charges (CSC). Parametric studies of CSC designs can be quickly and inexpensively conducted with the SCAP code. The code generated jet penetration versus standoff and jet tip velocity were shown to compare well with experimental data.

The CSC geometrical parametric study for a copper liner, aluminum tamper, and a secondary explosive (Octol) produced the following optimal CSC design parameters relative to the conical liner inside diameter $(D)$ :

$$
\begin{aligned}
& \text { 1. Apex angle }=45 \text { degrees, } \\
& \text { 2. Liner thickness }=0.01 \mathrm{D} \text {, } \\
& \text { 3. Explosive height }=(1.5 \mathrm{D}-2 \mathrm{D}) \text {, } \\
& \text { 4. Tamper thickness }=0.02 \mathrm{D} \text {, } \\
& \text { 5. Explosive width }=(1 \mathrm{D}-1.4 \mathrm{D}) \\
& \text { 6. Optimum standoff }=\text { (2D-6D) }
\end{aligned}
$$

Using similar liner, explosive and tamper materials, the optimal geometry shown in Figure 10 can be scaled to any diameter (D) CSC to produce a scaled jet penetration in mild steel targets. 
TABLE VIII.

Conical Shaped Charge Explosive Paramerers

\begin{tabular}{|c|c|c|c|c|c|}
\hline Explosive & $\begin{array}{l}\text { Density } \\
(\mathrm{g} / \mathrm{cc})\end{array}$ & $\begin{array}{l}\mathrm{D}_{\mathrm{e}} \\
(\mathrm{cm} / \mu \mathrm{S})\end{array}$ & $\begin{array}{l}\mathrm{V}_{\mathrm{g}} \\
(\mathrm{C} \mathrm{M} / \mu \mathrm{S})\end{array}$ & Gamma & $V_{g} / D_{e}$ \\
\hline LX-13 & 1.53 & 0.726 & 0.240 & 2.77 & 0.331 \\
\hline Octol & 1.81 & 0.848 & 0.278 & 2.79 & 0.328 \\
\hline Comp B & 1.72 & 0.802 & 0.272 & 2.76 & 0.339 \\
\hline PBX-9501 & 1.84 & 0.883 & 0.290 & 2.66 & 0.328 \\
\hline RDX & 1.80 & 0.880 & 0.286 & 2.82 & 0.325 \\
\hline $\begin{array}{l}\mathrm{D}_{\mathrm{e}} \\
\mathrm{V}_{\mathrm{g}}=(2 \mathrm{E})^{0.5} \\
\text { gamma }\end{array}$ & $\begin{array}{l}=\text { Detor } \\
=\text { Gurn } \\
=\text { Explo }\end{array}$ & $\begin{array}{l}\text { elocity } \\
\text { city } \\
\text { ponent }\end{array}$ & & & \\
\hline
\end{tabular}




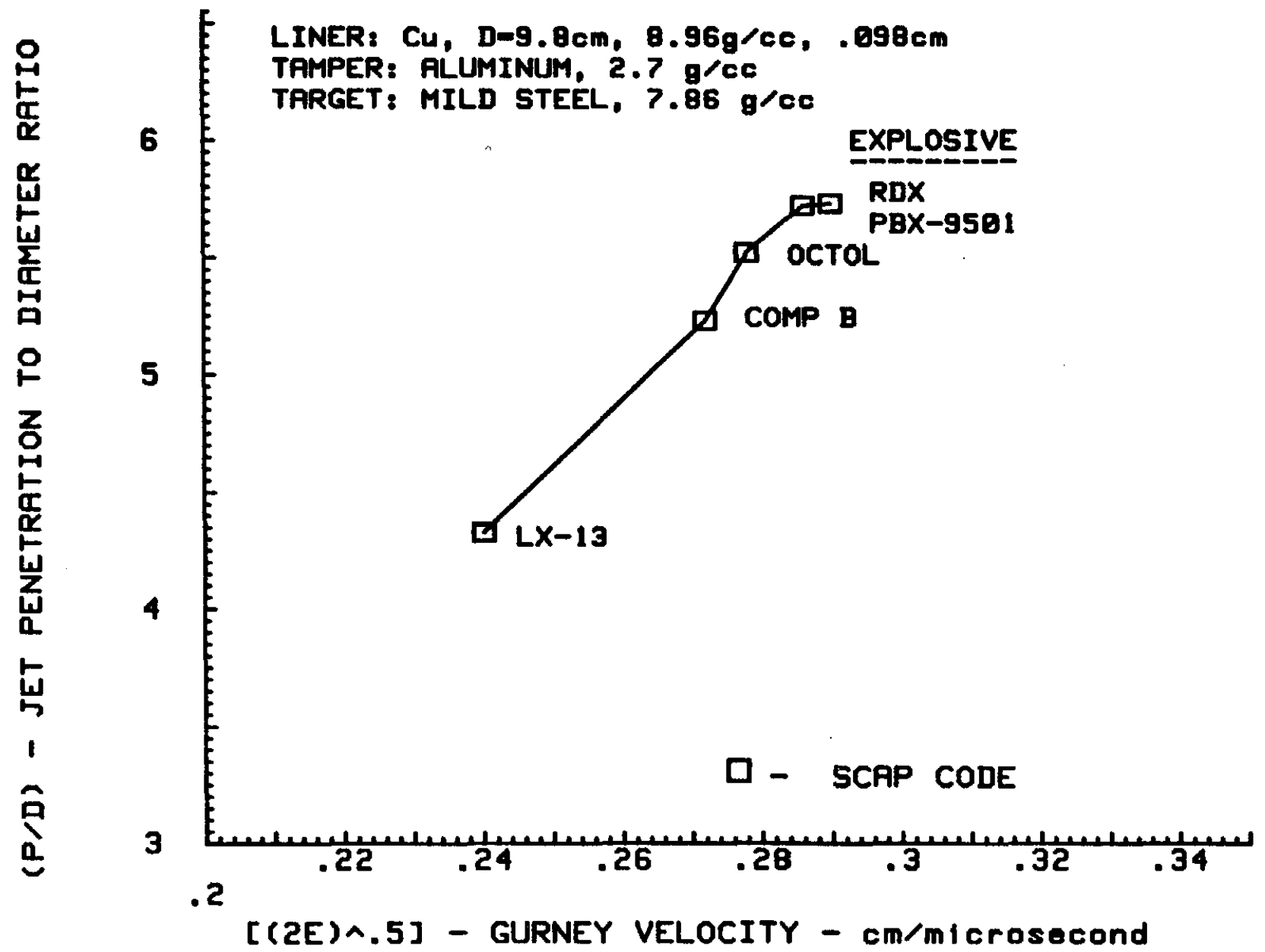

FIGURE 12 . CONICAL SHAPED CHARGE JET PENETRATION TO DIAMETER RATIO VERSUS GURNEY VELOCITY AND EXPLOSIVE 


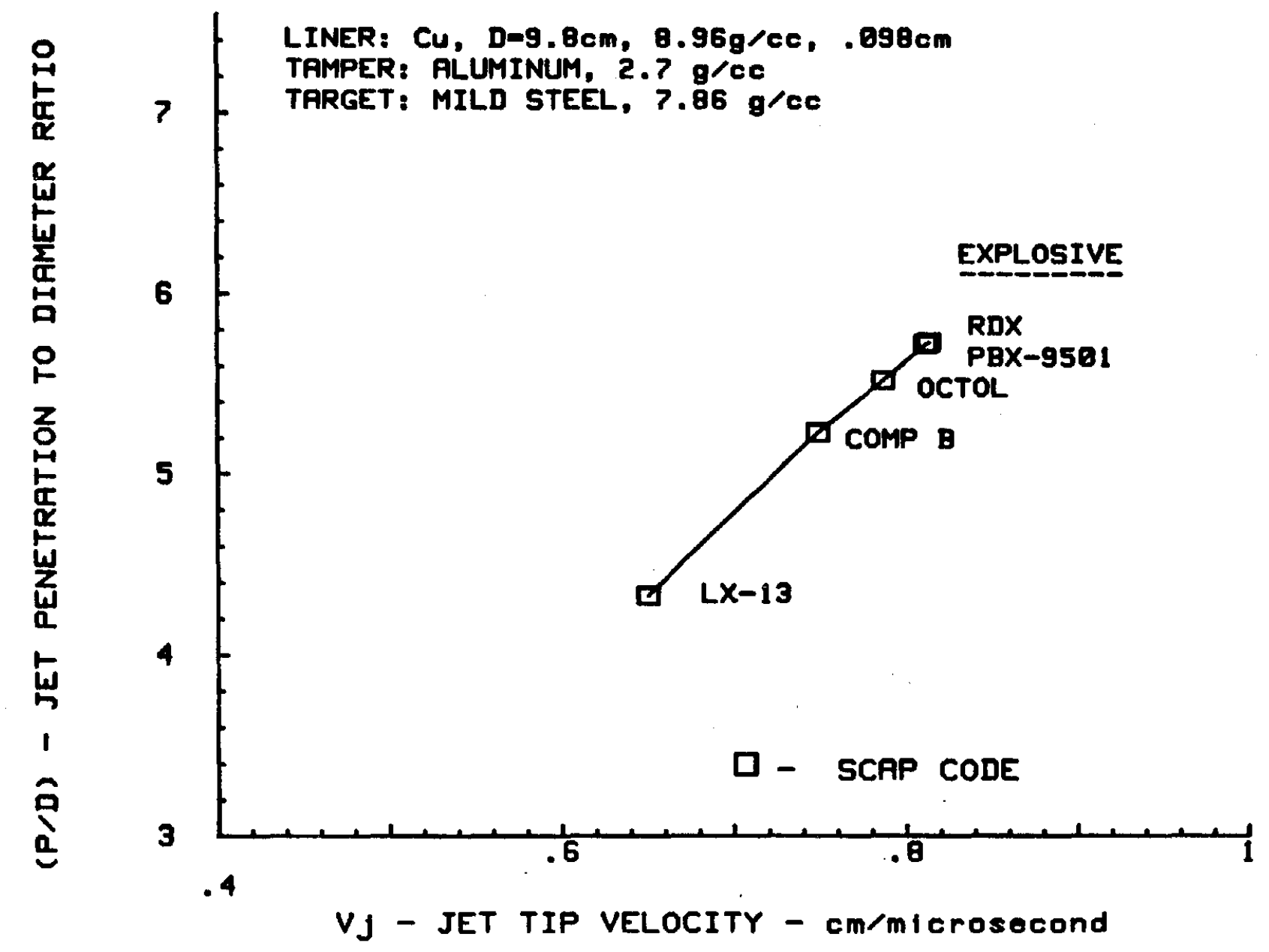

FIGURE 13. CONICAL SHAPED CHARGE JET PENETRATION TO DIAMETER RATIO VERSUS JET TIP VELOCITY AND EXPLOSIVE 


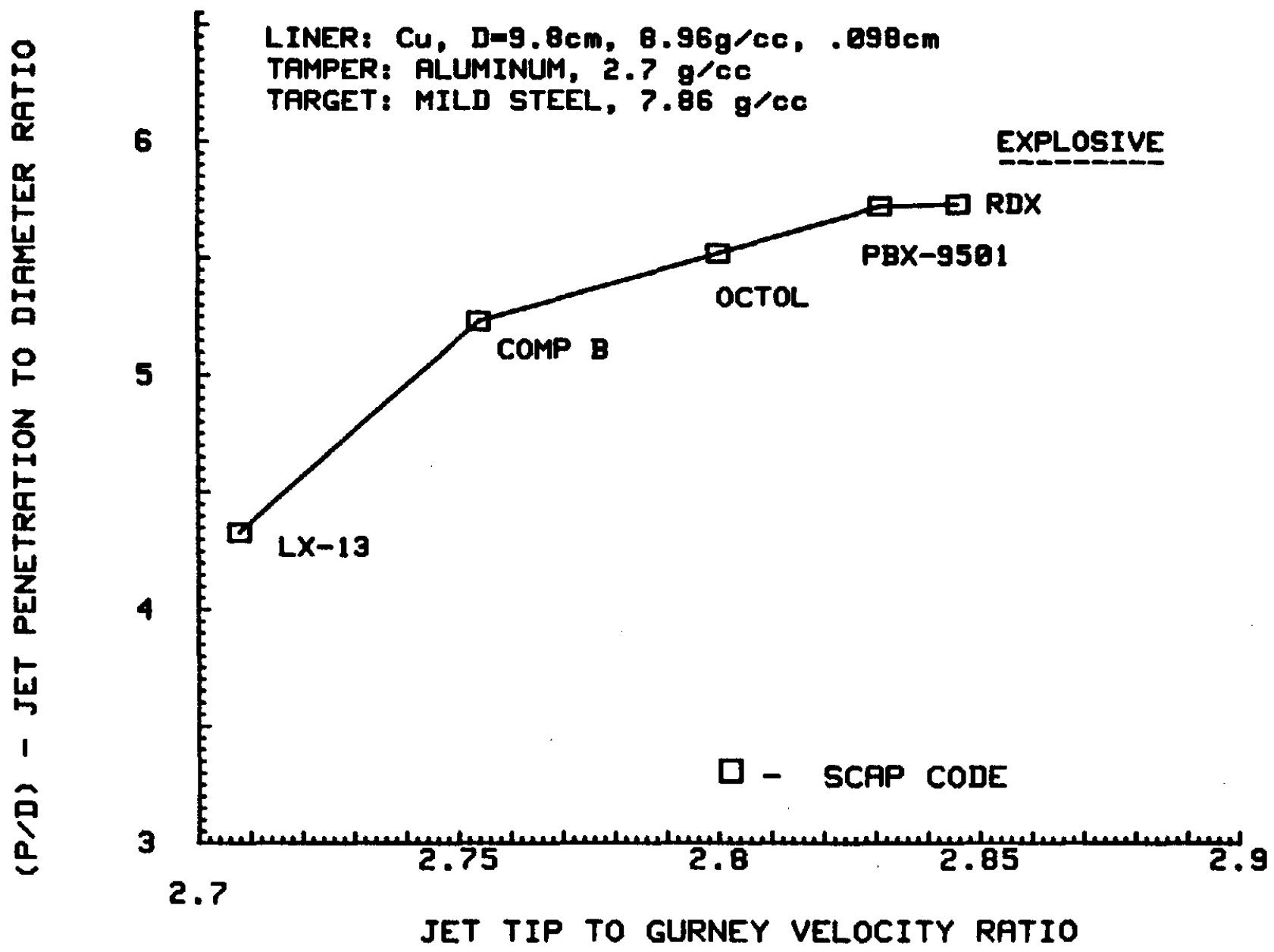

FIGURE 14. CONICAL SHAPED CHARGE JET PENETRATION TO DIAMETER RATIO VERSUS JET TO GURNEY VELOCITY AND EXPLOSIVE 


\section{TABLE IX.}

Conical Shaped Charge Jet Penetration versus Standoff and Explosive Data

Liner: Copper, 45 degree apex angle, .098 in thick, $8.90 \mathrm{~g} / \mathrm{cc}, 9.8 \mathrm{~cm}$ I.D.

Tamper: Aluminum, $2.7 \mathrm{~g} / \mathrm{cc}$,

Target: Milt Steel, $7.86 \mathrm{~g} / \mathrm{cc}$

$\mathrm{CD}=$ Cone Inside Diameter $(9.8 \mathrm{~cm})$

\begin{tabular}{|c|c|c|c|c|c|c|c|}
\hline \multirow[b]{2}{*}{ Explosive } & \multirow{2}{*}{$\begin{array}{l}V_{g} \\
(g / c c)\end{array}$} & \multirow{2}{*}{$\begin{array}{l}V_{j} \\
(\mathrm{~cm} / \mu S)\end{array}$} & \multicolumn{2}{|c|}{$\begin{array}{c}\text { Jet } \\
\text { Penetration }\end{array}$} & \multicolumn{2}{|c|}{$\begin{array}{l}\text { Optimum } \\
\text { Standoff }\end{array}$} & \multirow[b]{2}{*}{$V_{j} / V_{g}$} \\
\hline & & & $(\mathrm{CM})$ & (CD) & $(\mathrm{cm})$ & (CD) & \\
\hline LX-13 & 0.240 & 0.650 & 42.6 & 4.33 & 42.1 & 4.28 & 2.708 \\
\hline Comp B & 0.272 & 0.749 & 51.4 & 5.23 & 52.6 & 5.35 & 2.754 \\
\hline Octol & 0.278 & 0.787 & 54.3 & 5.52 & 52.6 & 5.35 & 2.831 \\
\hline RDX & 0.286 & 0.814 & 56.3 & 5.73 & 52.6 & 5.35 & 2.846 \\
\hline PBX-9501 & 0.290 & 0.812 & 56.3 & 5.72 & 52.6 & 5.35 & 2.800 \\
\hline
\end{tabular}

$\overline{\mathrm{V}_{\mathrm{g}}=(2 \mathrm{E})^{0.5}=\text { Gurney velocity }}$

$\mathrm{V}_{\mathrm{j}}=$ Jet tip velocity 


\section{APPENDIX A}

Section I. Selected CSC Analytical Experimental Parameters

Section II. SCAP Input Parameter Data File

Section III. CSC Cross-sections

Section IV. SCAP Model of Cross-section

Sectuib V. SCAP Code Jet Penetration Versus Standoff

Output Compared to Experimental Data 
APPENDIX A

Section I

Selected CSC Analytical-Experimental Parameters 
TABLE A I.

Conical Shaped Charge (CSC) Measured Parameters

\begin{tabular}{|c|c|c|c|c|c|c|c|c|c|c|}
\hline \multicolumn{5}{|c|}{ LINER } & \multicolumn{4}{|c|}{ EXPLOSIVE } & \multicolumn{2}{|l|}{ TAMPER } \\
\hline $\begin{array}{c}\mathrm{D} \\
\text { (in) } \\
\end{array}$ & $\underline{\text { Material }}$ & $\begin{array}{l}\text { Thick } \\
\text { (in) }\end{array}$ & $\begin{array}{l}\text { Apex } \\
\text { Angle } \\
\text { (deg) }\end{array}$ & $\begin{array}{c}\text { Height } \\
\text { (in) }\end{array}$ & Type & $\begin{array}{l}\text { Weight } \\
\text { (lb) }\end{array}$ & $\begin{array}{l}\text { Dia } \\
\text { (in) }\end{array}$ & $\begin{array}{l}\text { Height } \\
\text { (in) }\end{array}$ & Material & $\begin{array}{r}\text { Thick } \\
\text { (in) }\end{array}$ \\
\hline 0.690 & COPPER & .030 & 42 & 1.10 & PBX-9501 & 0.60 & .69 & 1.51 & PMMA & .250 \\
\hline 3.230 & COPPER & .081 & 42 & 3.84 & OCTOL & 1.90 & 3.20 & 5.51 & $\mathrm{AL}$ & .090 \\
\hline 3.860 & COPPER & .082 & 42 & 4.75 & OCTOL & 3.54 & 3.86 & 7.45 & $\mathrm{AL}$ & .080 \\
\hline 4.660 & COPPER & .105 & 60 & 4.10 & OCTOL & 5.33 & 4.87 & 6.70 & $\mathrm{AL}$ & .065 \\
\hline 9.125 & STEEL & .158 & 60 & 7.25 & COMP B & 30.00 & 9.13 & 15.50 & STEEL & .024 \\
\hline
\end{tabular}


TABLE A II.

Conical Shaped Charge (CSC) Analytical (SCAP) - Experimental Parameters

\begin{tabular}{|c|c|c|c|c|c|c|}
\hline \multirow{2}{*}{$\begin{array}{c}\mathrm{D} \\
\text { (in.) }\end{array}$} & \multicolumn{2}{|c|}{ Tip Velocity $(\mathrm{in} / \mu \mathrm{S})$} & \multicolumn{2}{|c|}{ OSO (in.) } & \multicolumn{2}{|c|}{$\mathbf{P}$ (in) } \\
\hline & Meas. & SCAP & Meas. & SCAP & Meas. & SCAP \\
\hline .690 & 0.620 & .564 & $*$ & 16.0 & $*$ & 14.5 \\
\hline 3.200 & 0.838 & .800 & 20.5 & 17.7 & 17.5 & 18.1 \\
\hline 3.860 & $*$ & .837 & 30.0 & 20.7 & 22.5 & 22.6 \\
\hline 4.660 & * & .775 & 32.0 & 24.9 & 25.0 & 24.3 \\
\hline 9.125 & 0.700 & .694 & $*$ & 31.0 & 30.0 & 29.7 \\
\hline
\end{tabular}

* - No data available

D - CSC Conical liner inside diameter

OSO - Optimum Standoff

P - CSC jet penetration 


\title{
APPENDIX A
}

\author{
Section II
}

SCAP Input Parameter Data Files

(Detailed discussion in Reference 1) 
TABLE AIII.

7-JUN-88 - 14:26:31 - XSCAP 2.0

\begin{tabular}{|c|c|c|c|c|c|c|c|}
\hline \multicolumn{2}{|c|}{ INPUT DECK - } & \multicolumn{2}{|c|}{ DRAG42CUST.DAT } & \multicolumn{4}{|c|}{ DRAG42CUST.LIS } \\
\hline $\begin{array}{l}\text { MASS } \\
\text { GM }\end{array}$ & $\begin{array}{l}\text { LENGTH } \\
\text { CM }\end{array}$ & $\begin{array}{l}\text { TIME } \\
\text { MICROSEC }\end{array}$ & IACCEL IO & $\begin{array}{r}\text { GURZN } \\
1\end{array}$ & ${ }_{2}^{S}$ IINTER I & ${ }_{1}^{\text {ISIMET IBRE }}$ & $\begin{array}{r}\mathbf{M K} \\
\mathbf{3}\end{array}$ \\
\hline $\begin{array}{rr}\text { IGEOM } & N 2 \\
2 & 70\end{array}$ & OCTOL ETYPE & $\begin{array}{r}\text { DEXP } \\
1.810 E+\infty 0\end{array}$ & $\begin{array}{r}\text { VDET } \\
8.486 E-\emptyset 1\end{array}$ & $\begin{array}{lr}\text { RT2E } \\
12.780 E-61\end{array}$ & $\begin{array}{r}\text { GAMMA } \\
2.790 E+\theta 6\end{array}$ & & \\
\hline $\begin{array}{r}\text { DLIN } \\
8.986 E+\$ 0 \\
\text { LINER PARA } \\
2.256 E+\% 1\end{array}$ & $\begin{array}{l}\text { VBLKL } \\
3.94 \theta E-61 \\
\text { AMETERS } \\
14.902 E+60\end{array}$ & $\begin{array}{r}\text { CUT JET } \\
1.866 E+60 \\
2.256 E+61\end{array}$ & $\begin{array}{r}\mathrm{TB} \\
1.256 E+02 \\
5.165 E+\theta 0\end{array}$ & $\begin{array}{lr}B & T 1 \\
2 & 2.256 E+62\end{array}$ & $\begin{array}{r}\text { YLIN } \\
2.260 E-63\end{array}$ & ML & $\begin{array}{r}\text { TBCON } \\
5.000 E+\infty 0\end{array}$ \\
\hline $\begin{array}{r}\text { DCON } \\
2.700 E+80 \\
\text { CONFINENEN } \\
6.806 E+60\end{array}$ & $\begin{array}{l}N C \\
N T \text { PARAMETES } \\
\text { E.165E+EO }\end{array}$ & Q & $5.168 E+60$ & & & & \\
\hline $\begin{array}{r}\text { HDET } \\
1.966 E+61\end{array}$ & $\begin{array}{l}\text { RDET } \\
10.000 E+E \theta\end{array}$ & $1.232 E+01$ & SOFMIN & $\begin{array}{l}N \\
\text { SOFMAX } \\
2.00 E+\infty 2\end{array}$ & $\begin{array}{r}\text { NSOFF } \\
20\end{array}$ & $\begin{array}{r}\text { NTL } \\
1\end{array}$ & \\
\hline $\begin{array}{r}\text { DTAR } \\
7.860 E+\varnothing \varnothing\end{array}$ & $\begin{array}{rr}R & \text { THICK } \\
8.500 E+\varnothing 1\end{array}$ & $\left\{\begin{array}{r}\text { UMIN } \\
1.400 E-61\end{array}\right.$ & 1 HOLEC & C $\begin{array}{r}\text { VMIN } \\
0.006 E+\infty \theta\end{array}$ & & & \\
\hline $\begin{array}{l}\text { CPRINT } \\
\text { PRINT }\end{array}$ & $\begin{array}{l}\text { CPLOT } \\
\text { NOPLOT }\end{array}$ & $\begin{array}{l}\text { CSHADE } \\
\text { SPARSE }\end{array}$ & $\begin{array}{l}\text { CMOVIE } \\
\text { NOMOVIE }\end{array}$ & $\begin{array}{l}X \operatorname{MAX} \\
3.784 E+61\end{array}$ & $\begin{array}{l}\text { XMIN } \\
1-7.076 E+\infty 0\end{array}$ & $\begin{array}{l}\operatorname{YmaX} \\
1.641 E+61\end{array}$ & $\begin{array}{l}\text { XYFAC } \\
1.666 E+60\end{array}$ \\
\hline $\begin{array}{l}\text { CSETUP } \\
\text { NOPLOT }\end{array}$ & $\begin{array}{l}\text { CCNVEL } \\
\text { NOPLOT }\end{array}$ & $\begin{array}{l}\text { CJTVEL } \\
\text { NOPLOT }\end{array}$ & $\begin{array}{l}\text { CAJTMS } \\
\text { NOPLOT }\end{array}$ & $\begin{array}{l}\text { CAJTMM } \\
\text { NOPLOT }\end{array}$ & $\begin{array}{l}\text { CAJTKEE } \\
\text { NOPLOT }\end{array}$ & $\begin{array}{l}\text { CBREAK } \\
\text { NOPLOT }\end{array}$ & $\begin{array}{l}\text { CPNSFF } \\
\text { NOPLOT }\end{array}$ \\
\hline $\begin{array}{l}\text { CPDETL } \\
\text { NONE }\end{array}$ & CSOUT• & & $\bullet$ & & & & \\
\hline $\begin{array}{l}\text { CSNPST } \\
\text { NOSNAP }\end{array}$ & $\begin{array}{r}\text { NPP } \\
6\end{array}$ & $\begin{array}{l}\text { TOUT } \\
2.006 E+61\end{array}$ & $0.600 \varepsilon+$ & $100.600 \mathrm{E}$ & $0.660 E+6$ & $6.000 \mathrm{E}$ & \\
\hline
\end{tabular}


TABLE A IV.

4.66 Inch I.D. CSC SCAP Input Data File

7-JUN-88- 14:36:38- XSCAP 2.6

INPUT DECK - TOWBECUST.OAT THIS FILE - TOWBECUST.LIS

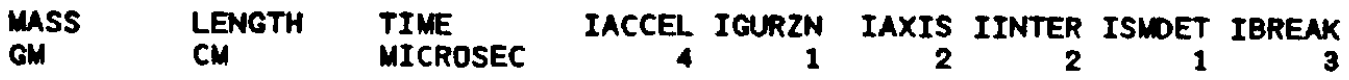

IGEOM NZ 2 ETYPE $\begin{aligned} & \text { DEXP } \\ & 70 \text { OCTOL }\end{aligned}$

DLIN VBLKL CUTJET TB TI TLIN TH TON

8.966E+60 3.946E-61 $1.006 E+601.766 E+62$
LINER PARAMETERS

$3.000 E+61$ 6.185E+60 3.600E+01 $6.356 E+60$

$\begin{array}{rr}\text { DCON } & \text { NC } \\ 2.760 E+60 & 8\end{array}$

CONFINEMENT PARAMETERS

$0.060 E+606.466 E+000.000 E+606.764 E+601.760 E+011.766 E+612.160 E+012.100 E+01$

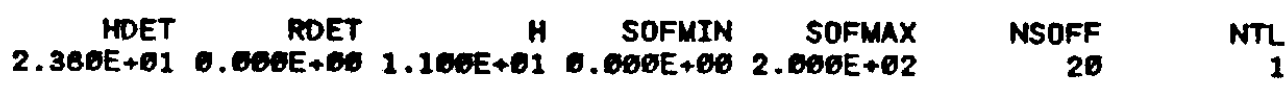

DTAR THICK UMIN HOLEC VMIN

CPRINT CPLOT CSHADE CMOVIE XMAX XMIN YMAX XYFAC

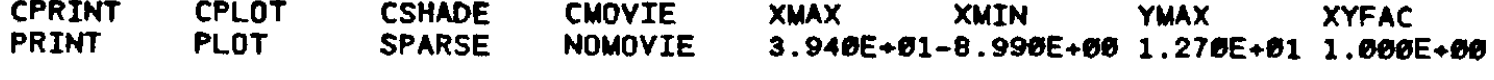

$\begin{array}{lllllll}\text { CSETUP CCNVEL CJTVEL CAJTMS } & \text { CAJTMM CAJTKE } & \text { CBREAK } & \text { CPNSFF } \\ \text { PLOT } & \text { NOPLOT } & \text { NOPLOT } & \text { NOPLOT } & \text { NOPLOT } & \text { NOPLOT }\end{array}$

CPDETL CSOUT:

NONE

CSNPST NPP TOUT

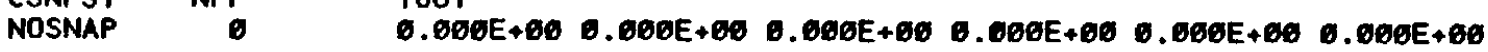


M3STEEL.DAT - 7-JUN-88 - 14:46:52 - XSCAP 2.0

INPUT DECK - MSSTEEL.DAT THIS FILE - M3STEEL.LIS

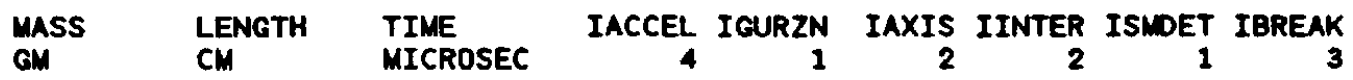

IGEOM NZ ETYPE DEXP VDET RT2E GAMMA

252 COMP B $1.726 E+\infty 67.996 E-61 \quad 2.686 E-61 \quad 2.996 E+66$

DLIN VBLKL CUTJET TB TI YLIN NL TBCON

$7.866 E+66$ 4.576E-61 1.006E+60 2.256E+62 2.256E+62 7.906E-63 LINER PARAMETERS

3.606E+B1 1.265E+ 3.61 3.06E+61 1.251E+ 1

DCON
$7.866 E+60$

CONFINEMENT PARAMETERS

$6.606 E+601.251 E+01 \quad 0.060 E+661.258 E+61 \quad 1.786 E+611.762 E+613.606 E+013.000 E+01$

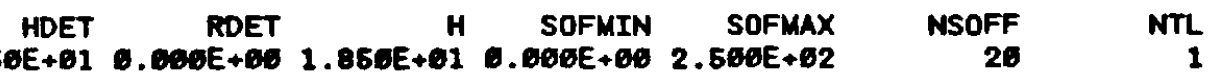

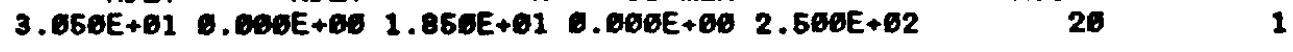

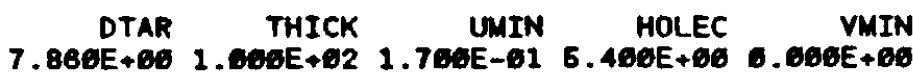

\begin{tabular}{|c|c|c|c|c|c|c|c|}
\hline $\begin{array}{l}\text { CPRINT } \\
\text { PRINT }\end{array}$ & $\begin{array}{l}\text { CPLOT } \\
\text { PLOT }\end{array}$ & $\begin{array}{l}\text { CSHADE } \\
\text { SPARSE }\end{array}$ & $\begin{array}{l}\text { CMOVIE } \\
\text { NOMOVIE }\end{array}$ & $\begin{array}{l}\text { XMAX } \\
6.574 E\end{array}$ & $\begin{array}{c}\text { XMIN } \\
1-1.126 E+61\end{array}$ & $\begin{array}{l}\text { YMAX } \\
2.516 E+01\end{array}$ & $\begin{array}{l}\text { XYFAC } \\
1.000 E+\infty 0\end{array}$ \\
\hline $\begin{array}{l}\text { CSETUP } \\
\text { PLOT }\end{array}$ & $\begin{array}{l}\text { CCNVEL } \\
\text { MOPLOT }\end{array}$ & $\begin{array}{l}\text { C JTVEL } \\
\text { NOPLOT }\end{array}$ & $\begin{array}{l}\text { CAJTMS } \\
\text { NOPLOT }\end{array}$ & $\begin{array}{l}\text { CAJTMM } \\
\text { NOPLOT }\end{array}$ & $\begin{array}{l}\text { CAJTKE } \\
\text { NOPLOT }\end{array}$ & $\begin{array}{l}\text { CBREAK } \\
\text { NOPLOT }\end{array}$ & $\begin{array}{l}\text { CPNSFF } \\
\text { NOPLOT }\end{array}$ \\
\hline $\begin{array}{l}\text { CPDETL } \\
\text { NONE }\end{array}$ & CSOUT. & & $\bullet$ & & & & \\
\hline $\begin{array}{l}\text { CSNPST } \\
\text { NOSNAP }\end{array}$ & $\begin{array}{r}\text { NPP } \\
6\end{array}$ & $\begin{array}{l}\text { TOUT } \\
\text { G. BEEE }\end{array}$ & $0.600 \mathrm{E}$ & $6.080 E$ & $0.060 E+60$ & $0.00 \sigma E+\sigma \theta$ & $0.006 \mathrm{E}+6 \theta$ \\
\hline
\end{tabular}




\section{TABLE A VI.}

3.23 Inch I.D. SCAP Input Data File

362CU42ST.DAT - T-JUN-88 - 14:42:60 - XSCAP 2.6

INPUT DECK - 362CU42ST.DAT THIS FILE - $\quad 302 C U 42 S T . L I S$

\begin{tabular}{|c|c|c|c|c|c|c|c|}
\hline $\begin{array}{l}\text { MASS } \\
\text { GM }\end{array}$ & $\begin{array}{l}\text { LENGTH : } \\
\text { CM }\end{array}$ & $\begin{array}{l}\text { TIME } \\
\text { MICROSEC }\end{array}$ & $\underset{4}{\text { IACCEL }}$ & $\begin{array}{r}\text { IGURZN } \\
1\end{array}$ & $\begin{array}{r}\text { IAXIS } \\
2\end{array}$ & $\begin{array}{r}\text { IINTER } \\
2\end{array}$ & $\begin{array}{rr}\text { ISMDET IBREAK } \\
1\end{array}$ \\
\hline
\end{tabular}

IGEOM NZ ETYPE DEXP VDET RT2E GAMMA

239 OCTOL $1.810 E+668.486 E-012.786 E-61 \quad 2.770 E+60$
DLIN
VBLKL
CUT JET
TB
T1
YLIN
8.966E+60 3.946E-61 1.606E+60 1.636E+62 1.030E+62 2.206E-63 LINER PARAMETERS

$2.166 \mathrm{E}+61 \quad 4.102 \mathrm{E}+662.160 \mathrm{E}+014.318 \mathrm{E}+60$

DCON
$2.700 E+60$

$2.700 E+60$
CONFINEMENT PARAMETERS

$0.066 E+604.318 E+606.600 E+604.647 E+60 \quad 0.760 E+601.689 E+61 \quad 2.106 E+612.100 E+01$

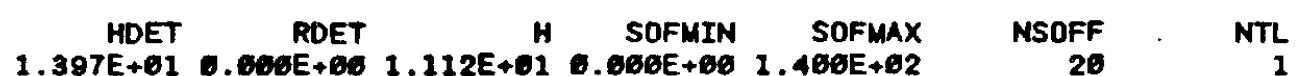

DTAR THICK UMIN HOLEC VMIN

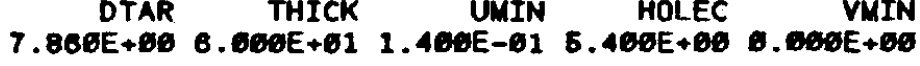

\begin{tabular}{|c|c|c|c|c|c|c|c|}
\hline $\begin{array}{l}\text { CPRINT } \\
\text { PRINT }\end{array}$ & $\begin{array}{l}\text { CPLOT } \\
\text { PLOT }\end{array}$ & $\begin{array}{l}\text { CSHADE } \\
\text { SPARSE }\end{array}$ & $\begin{array}{l}\text { CMOVIE } \\
\text { NOMOVIE }\end{array}$ & $\begin{array}{l}X \operatorname{MAX} \\
2.794 E\end{array}$ & $\begin{array}{l}\text { XMIN } \\
1-2.726 E+60\end{array}$ & $\begin{array}{l}\text { YMAX } \\
9.894 E+60\end{array}$ & $\begin{array}{l}\text { XYFAC } \\
1.006 E+\varnothing \theta\end{array}$ \\
\hline $\begin{array}{l}\text { CSETUP } \\
\text { PLOT }\end{array}$ & $\begin{array}{l}\text { CCNVEL } \\
\text { NOPLOT }\end{array}$ & $\begin{array}{l}\text { CJTVEL } \\
\text { PLOT }\end{array}$ & $\begin{array}{l}\text { CAJTMS } \\
\text { NOPLOT }\end{array}$ & $\begin{array}{l}\text { CAJTMM } \\
\text { NOPLOT }\end{array}$ & $\begin{array}{l}\text { CAJTKE } \\
\text { NOPLOT }\end{array}$ & $\begin{array}{l}\text { CBREAK } \\
\text { NOPLOT }\end{array}$ & $\begin{array}{l}\text { CPNSFF } \\
\text { NOPLOT }\end{array}$ \\
\hline $\begin{array}{l}\text { CPDETL } \\
\text { NONE }\end{array}$ & CSOUT: & $\bullet$ & $\bullet$ & & & & \\
\hline $\begin{array}{l}\text { CSNPST } \\
\text { NOSNAP }\end{array}$ & $\underset{0}{\mathrm{NPP}}$ & $\begin{array}{l}\text { TOUT } \\
1 . \text {. }\end{array}$ & $0.000 \mathrm{E}$ & 0.060 & $10 \cdot .666 E+6 \theta$ & $6.000 E+60$ & $00.000 E+\theta 0$ \\
\hline
\end{tabular}




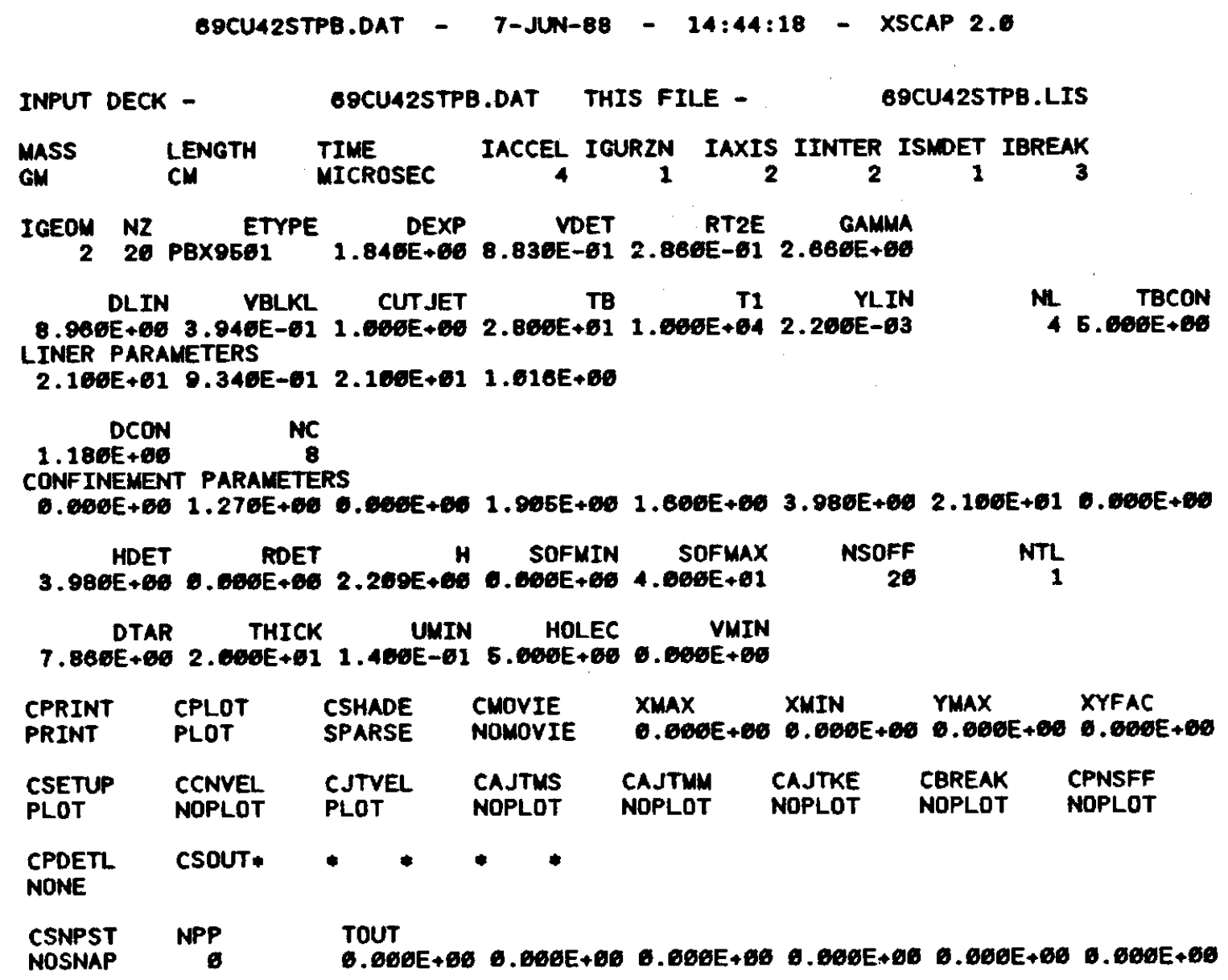




\section{APPENDIX A}

Section III

Selected CSC Cross-sections 


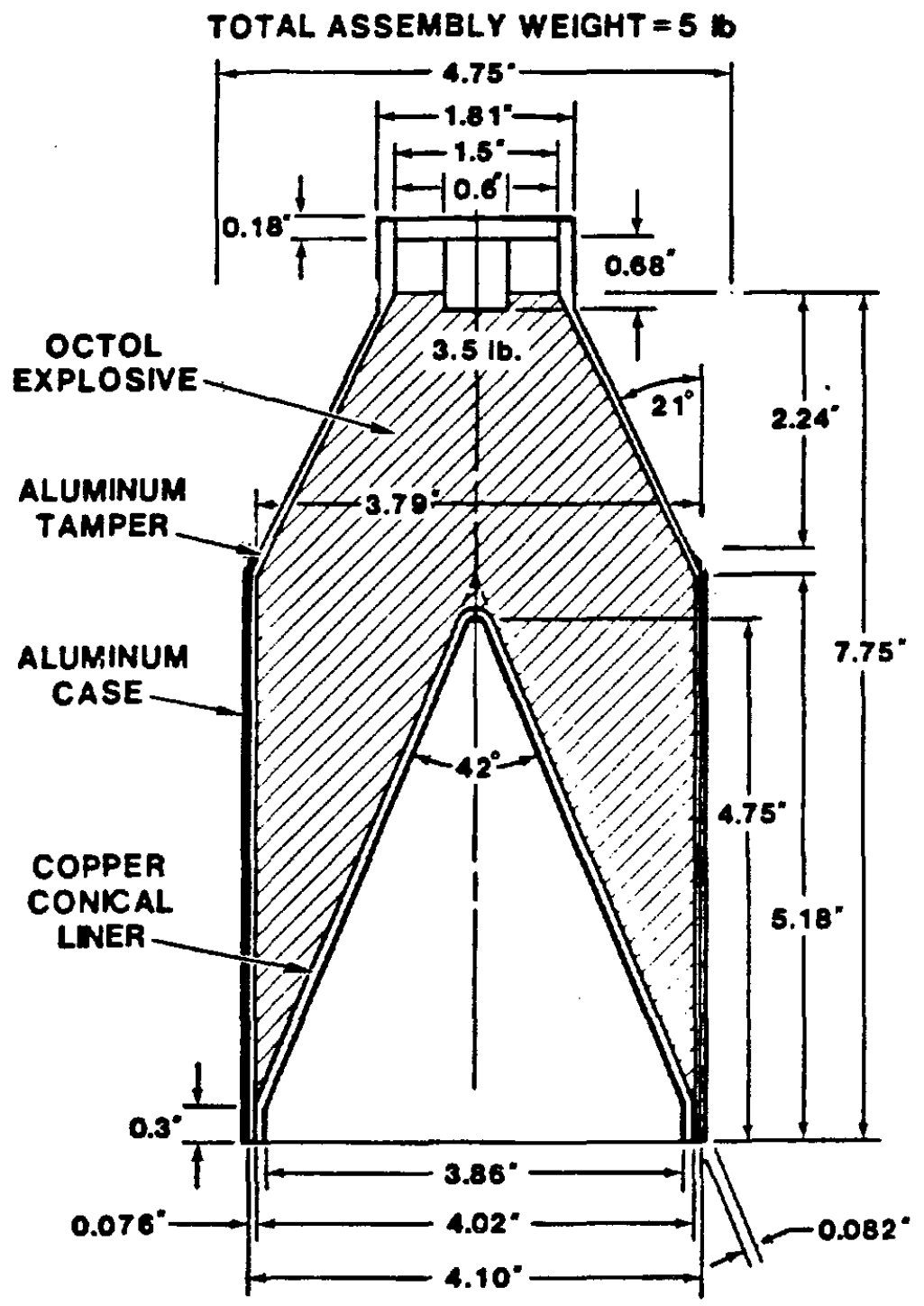

Figure A1. 3.86 Inch Diameter CSC Cross-Section 


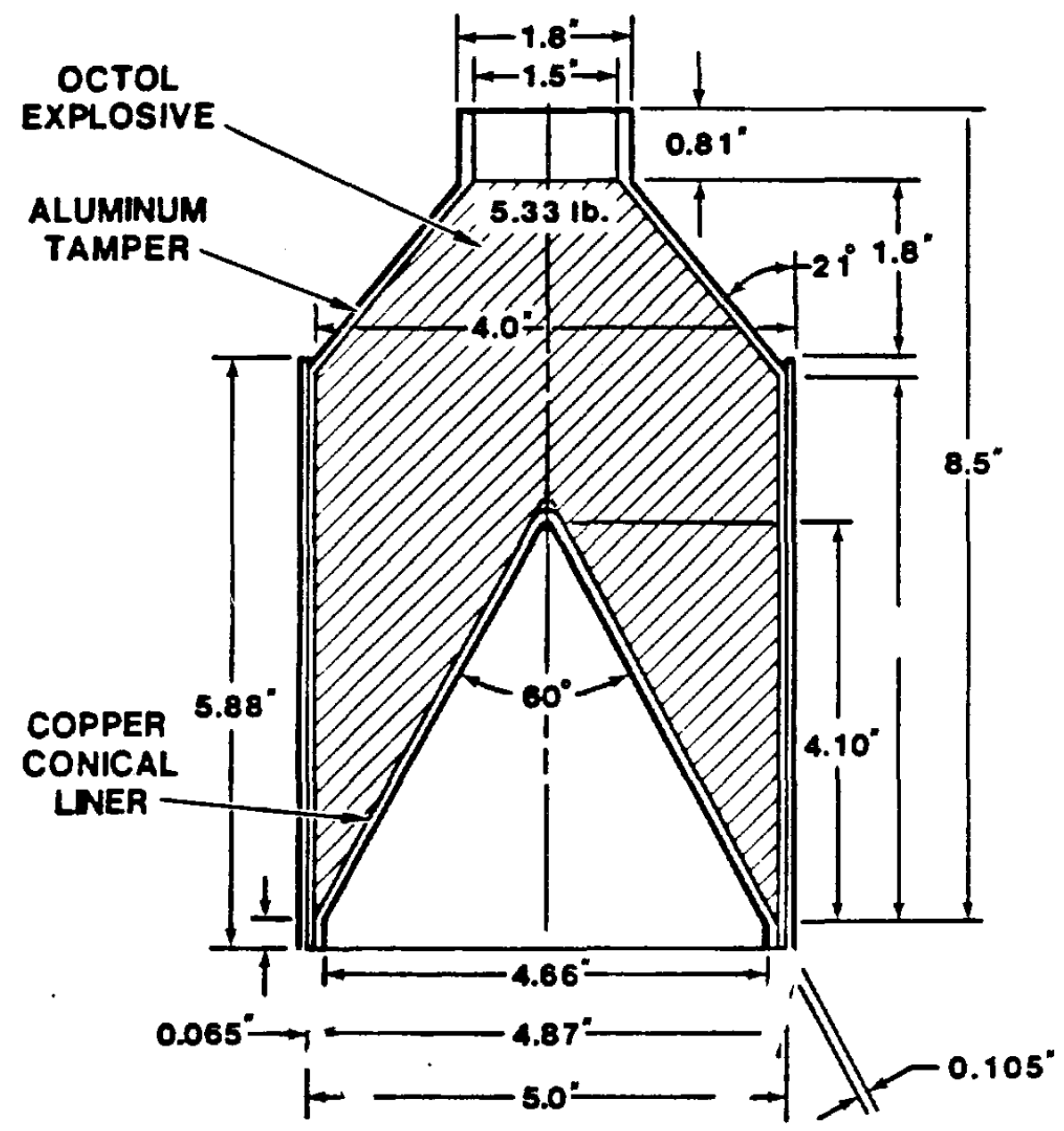

Figure A2. 4.66 Inch Diameter CSC Cross-Section 


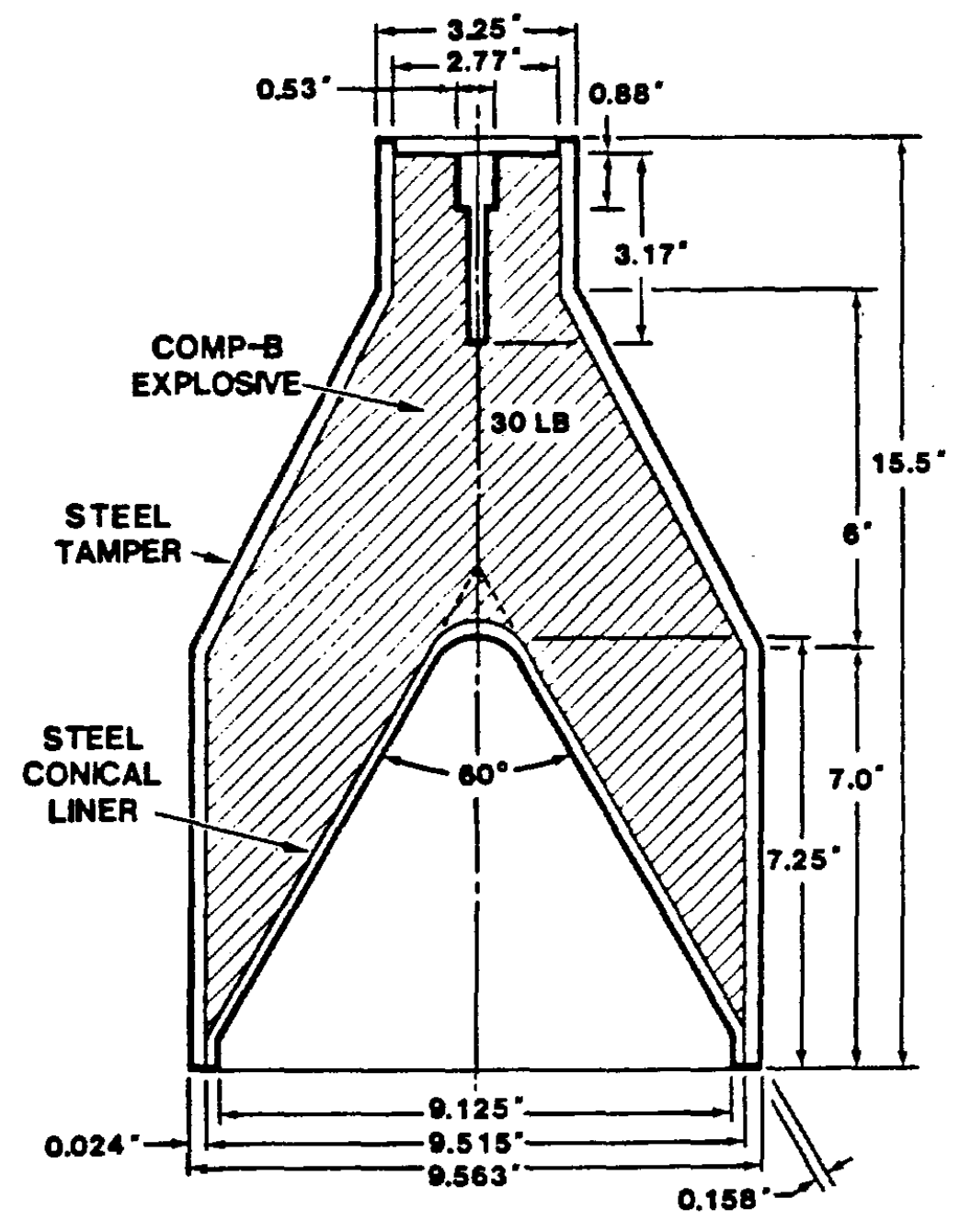

Figure A 3. M3 9.125 Inch Diameter CSC Cross-Section 


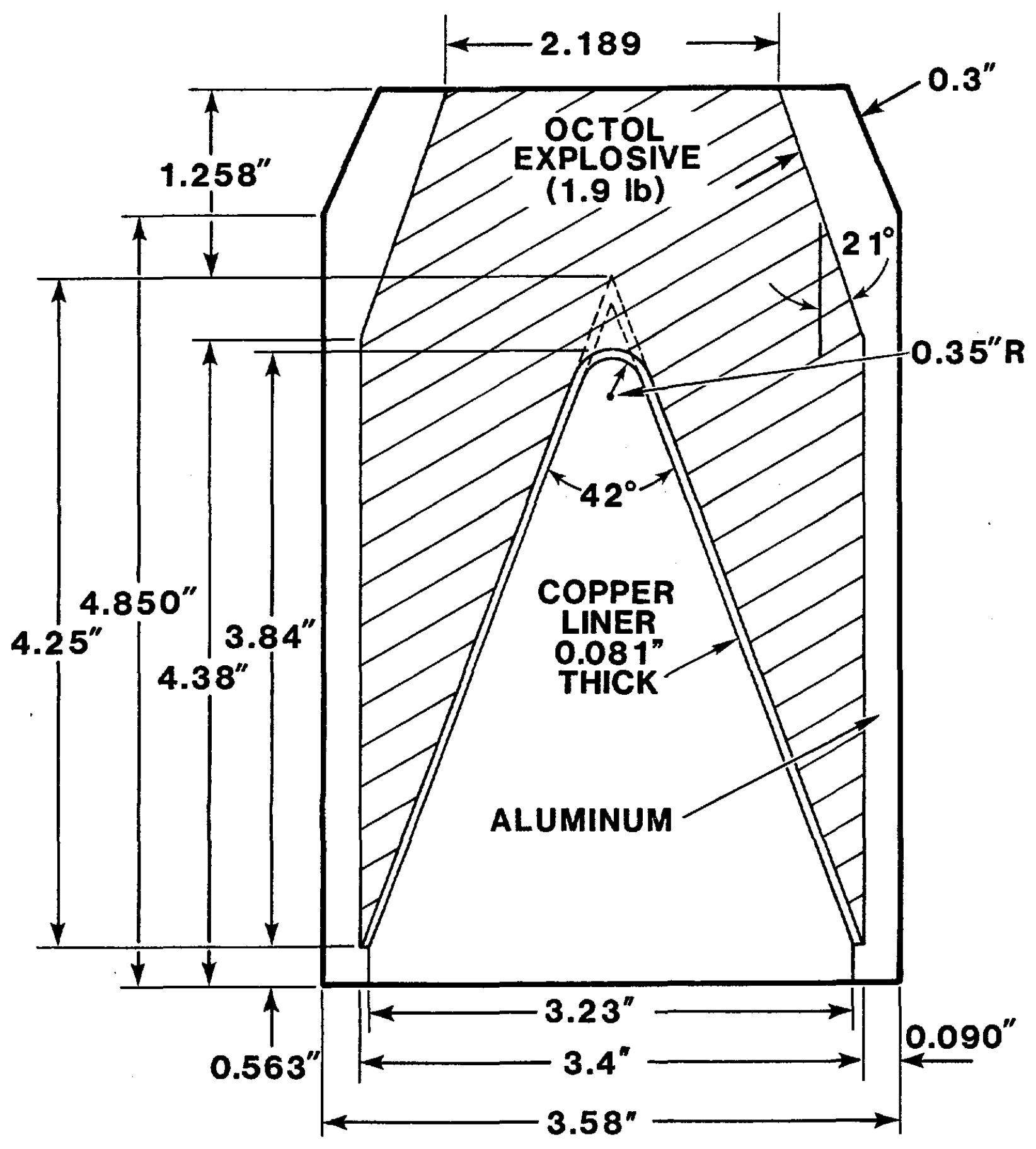

Figure A4. 3.23 Inch Diameter Conical Shaped Charge Cross-section 


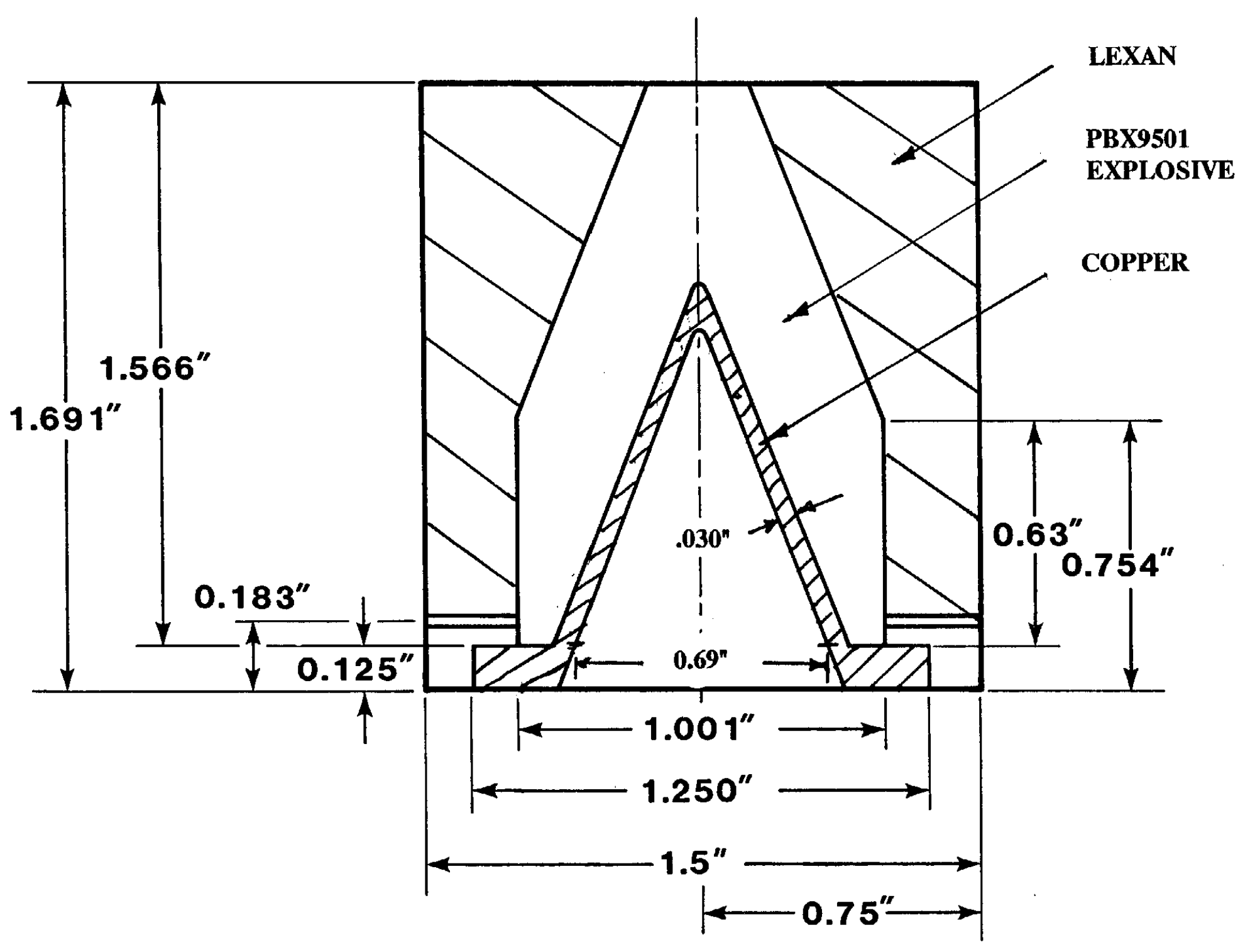

Figure A5. 0.69 Inch Diameter CSC Cross-section 
APPENDIX A

Section IV

SCAP CSC Modeling Cross-sections 


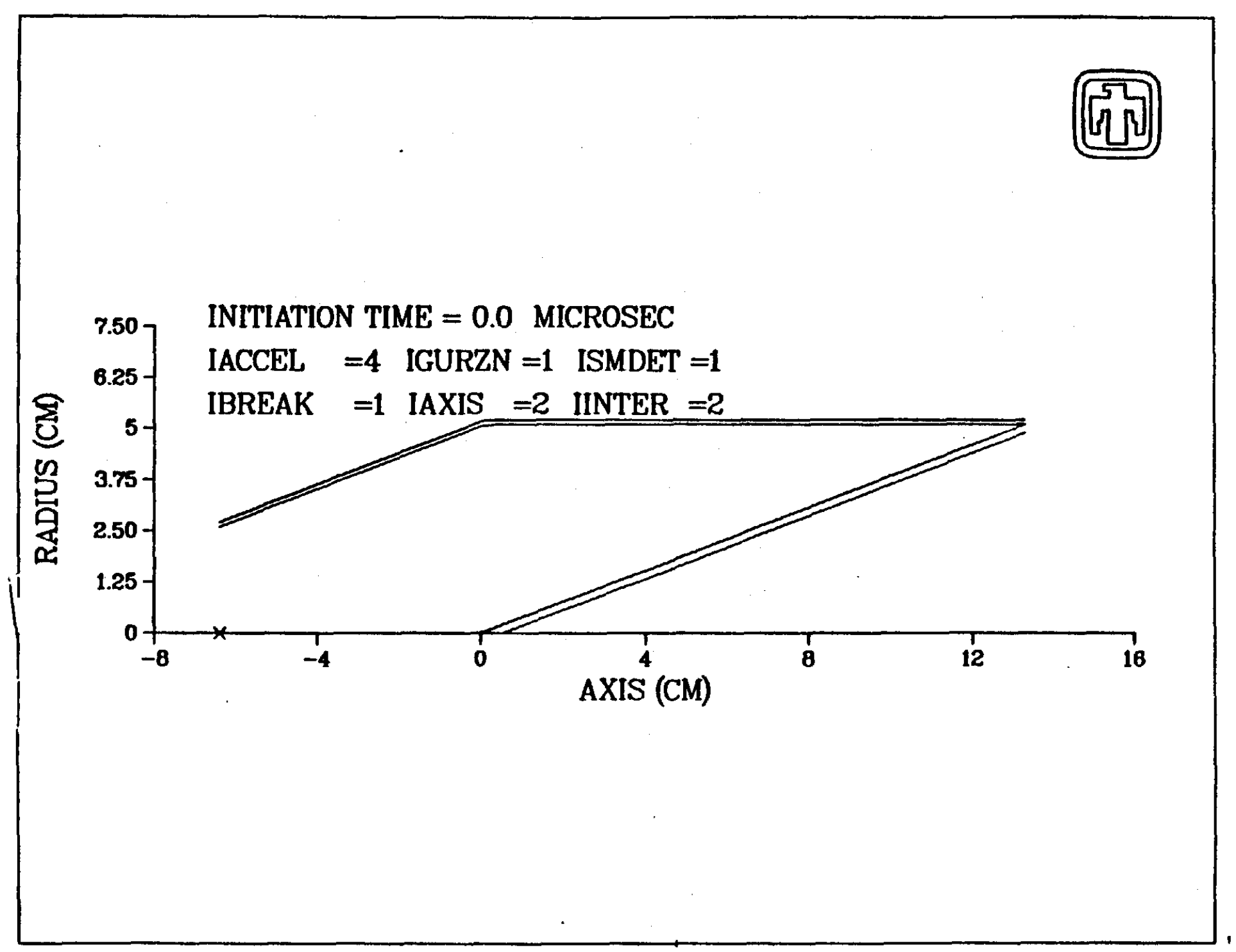

Figure A6. 3.86 Inch I.D. CSC 


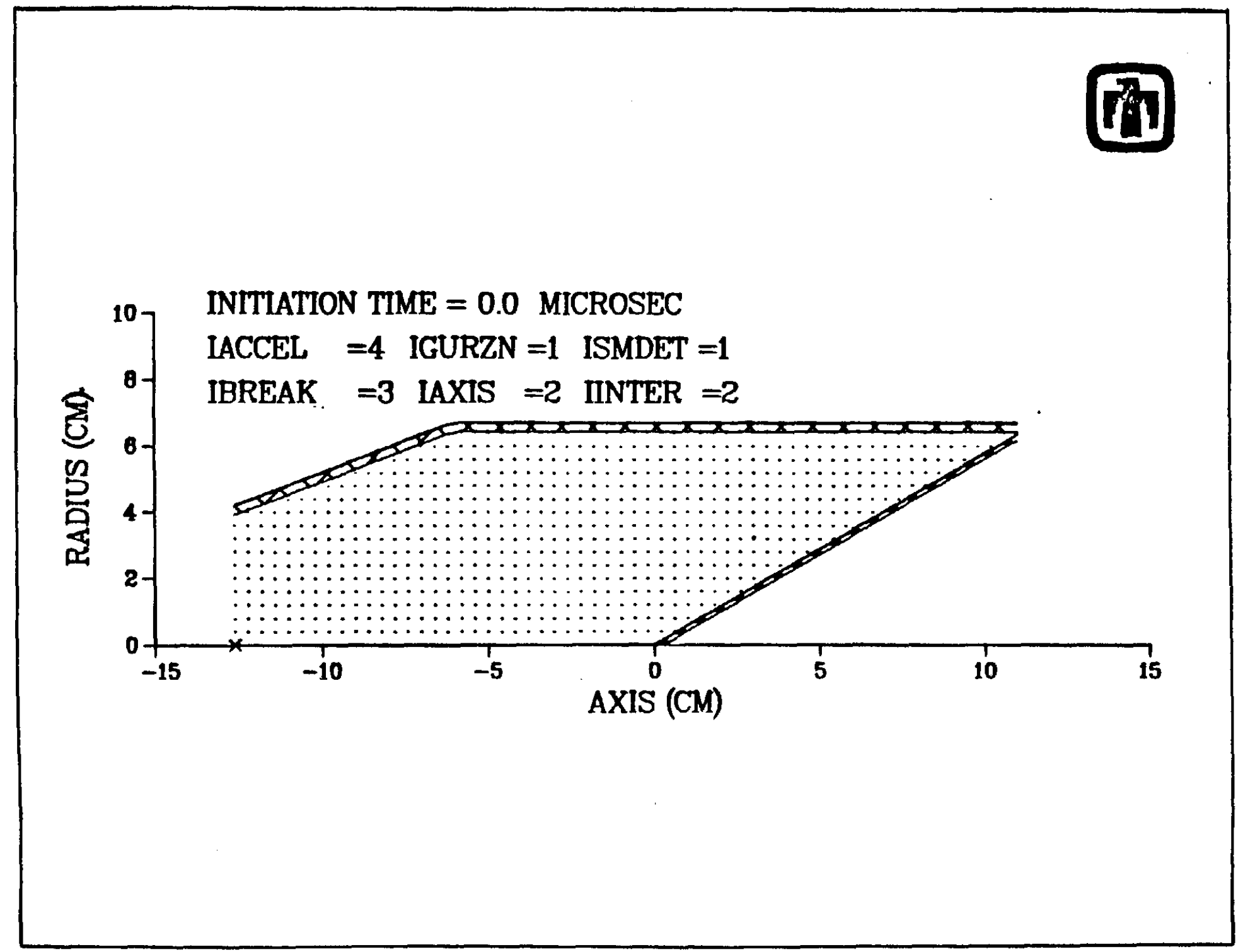

Figure A7. 4.87 Inch I.D. CSC 


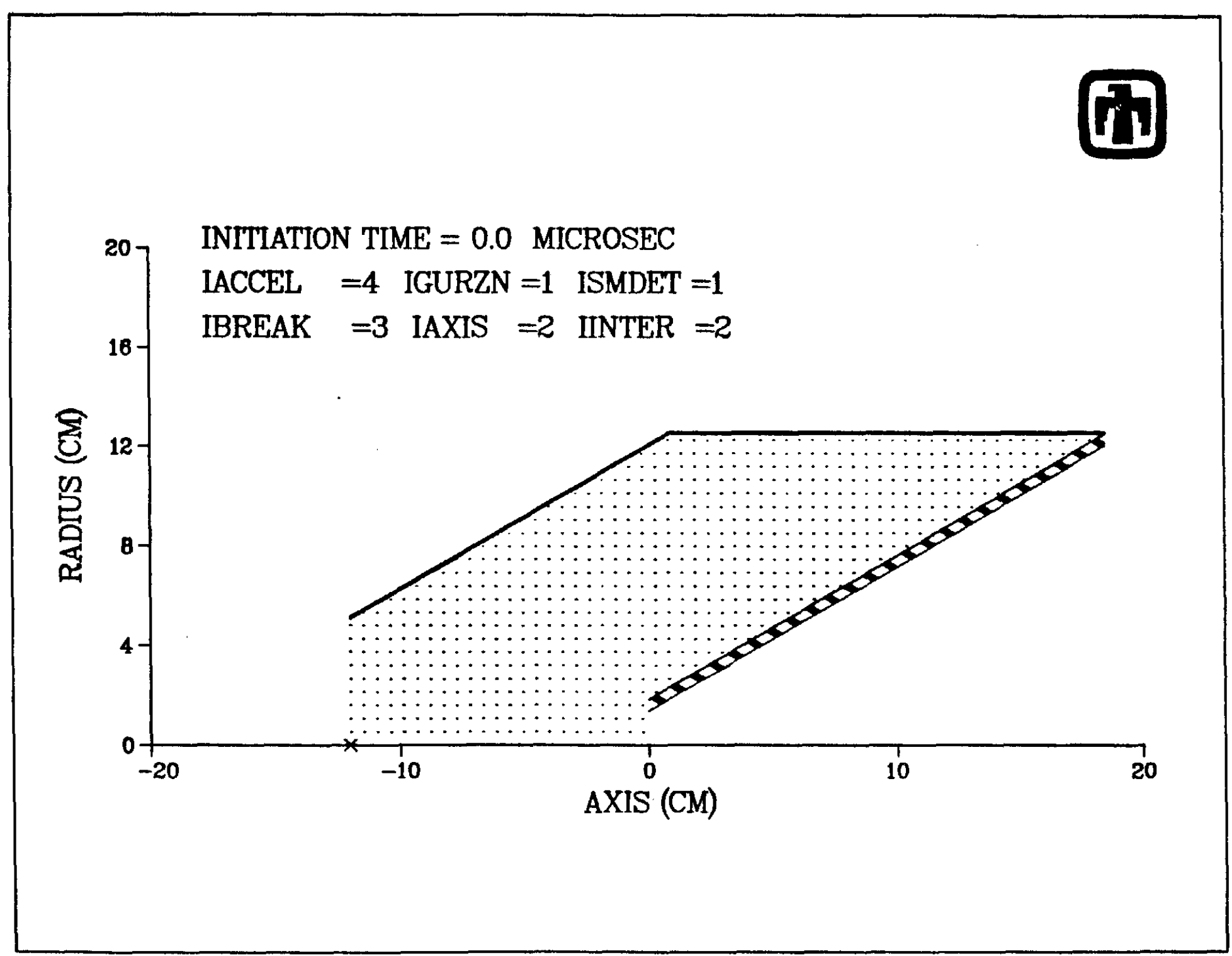

Figure A8. M3 9.125 Inch I.D. CSC 


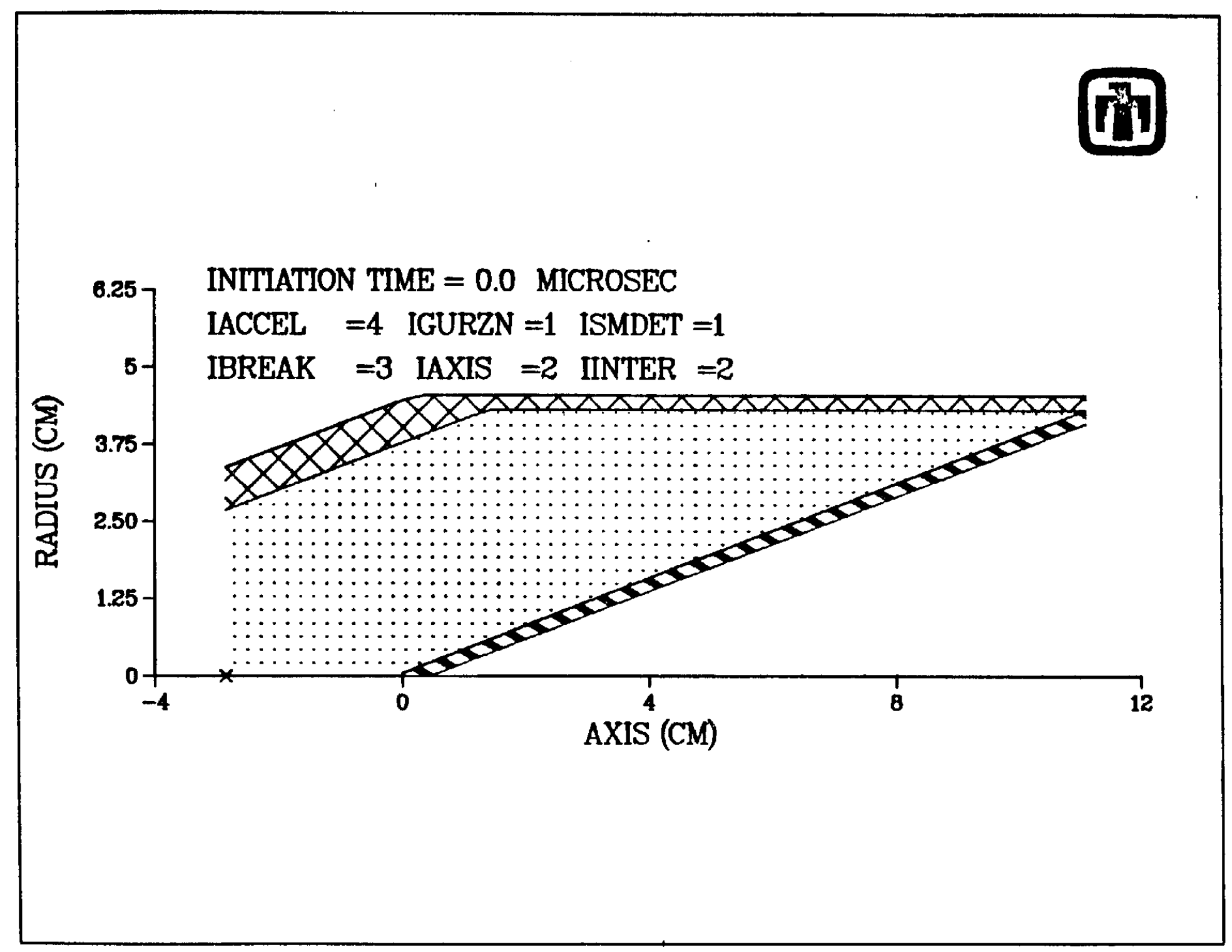




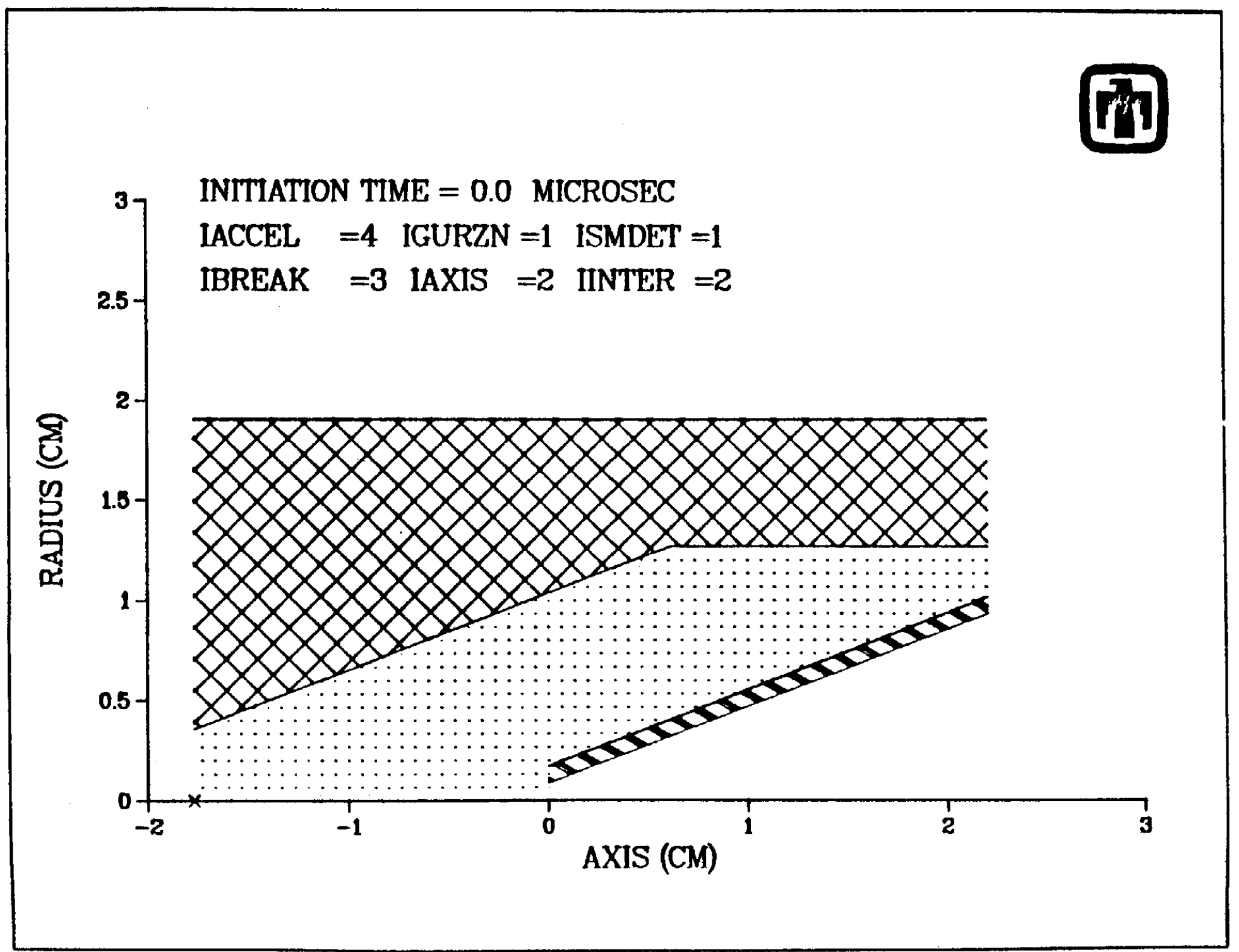

Figure A10. 0.69 Inch I.D. CSC 


\section{APPENDIX A}

\section{Section V}

SCAP Code Jet Penetration Versus

Standoff Output Compared to Experimental Data 


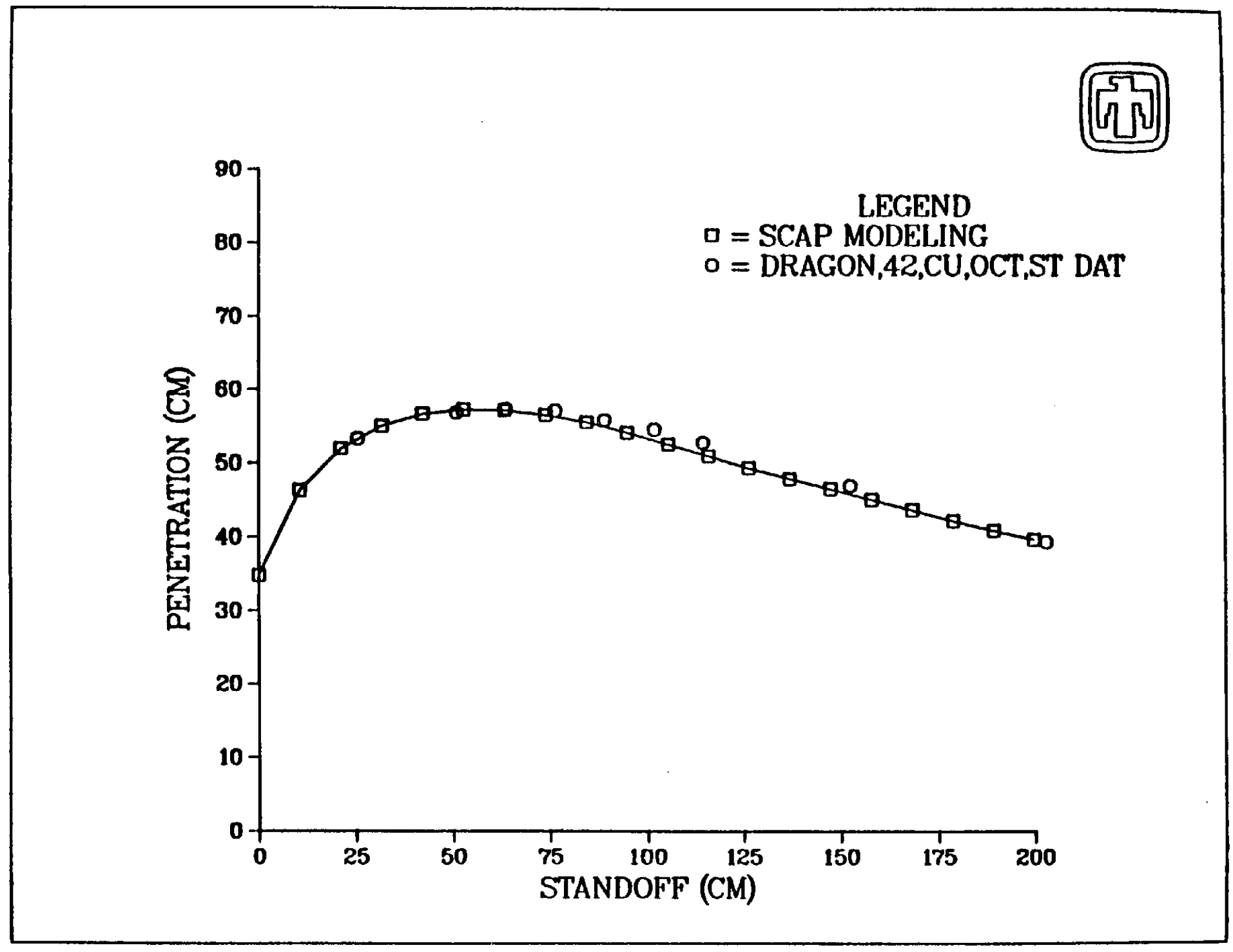

Figure A11. CSC Jet Penetration Versus Standoff Analytical-Experimental Comparison 


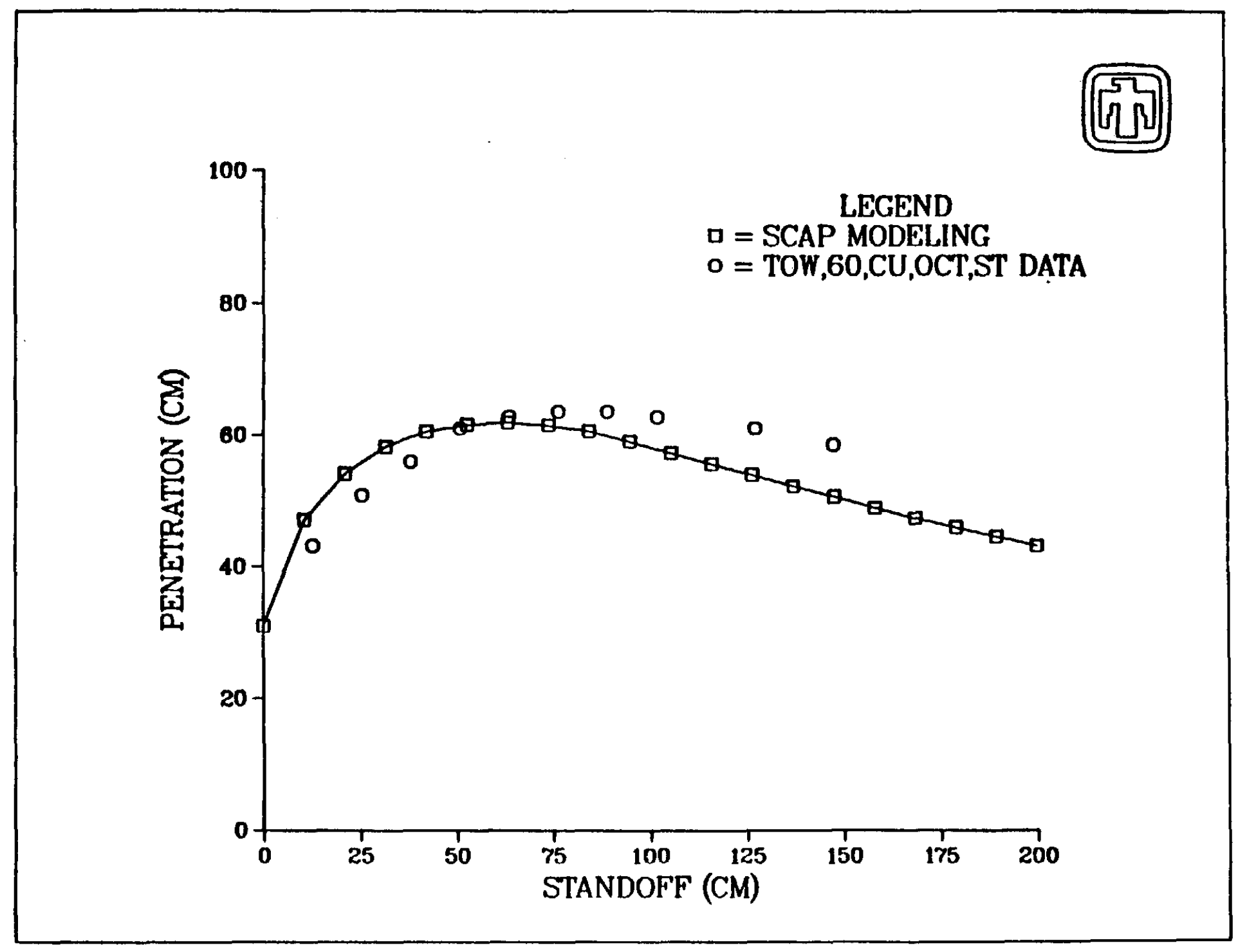




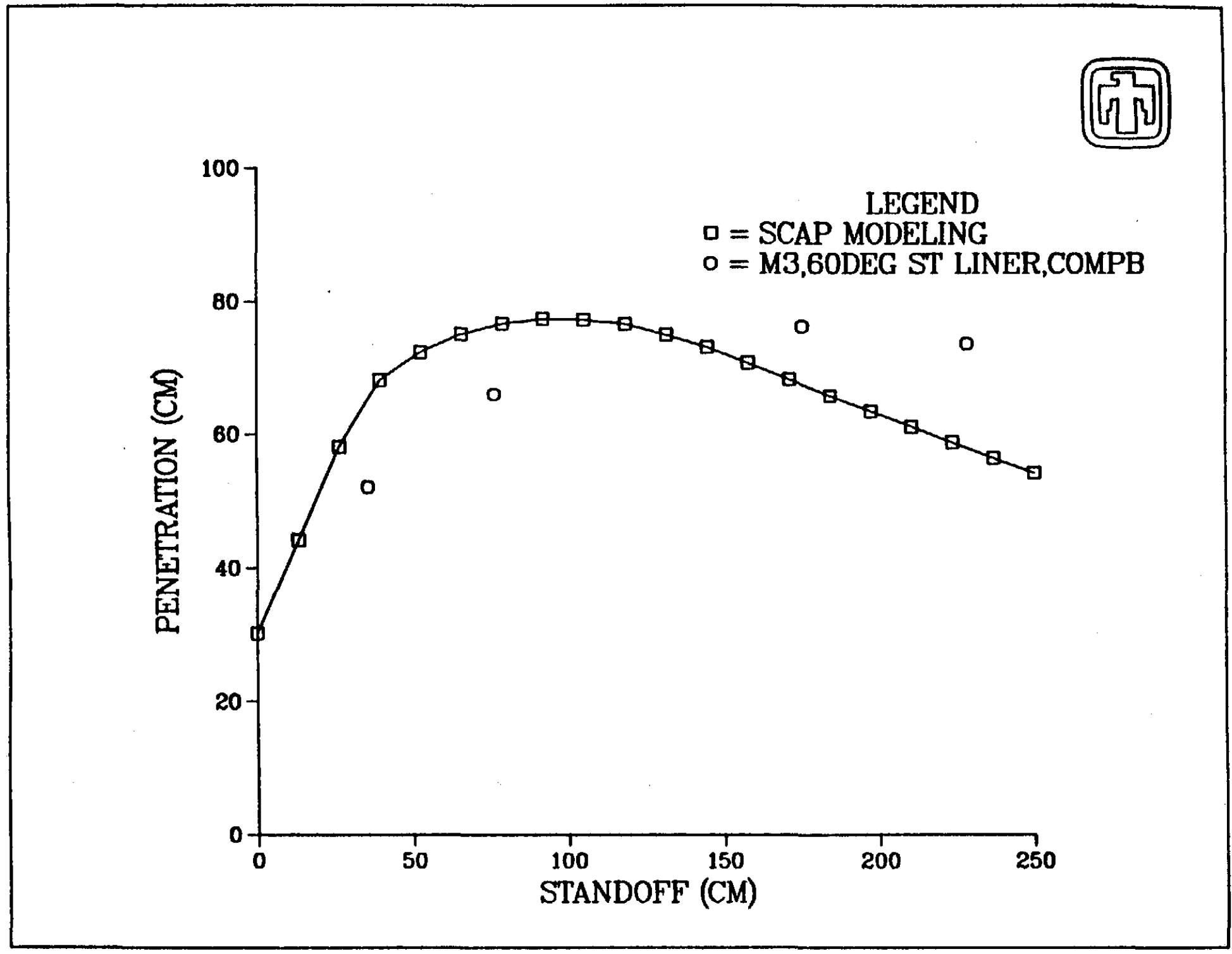

Figure A13. M3 CSC Jet Penetration Versus Standoff Analytical-Experimental Comparison 


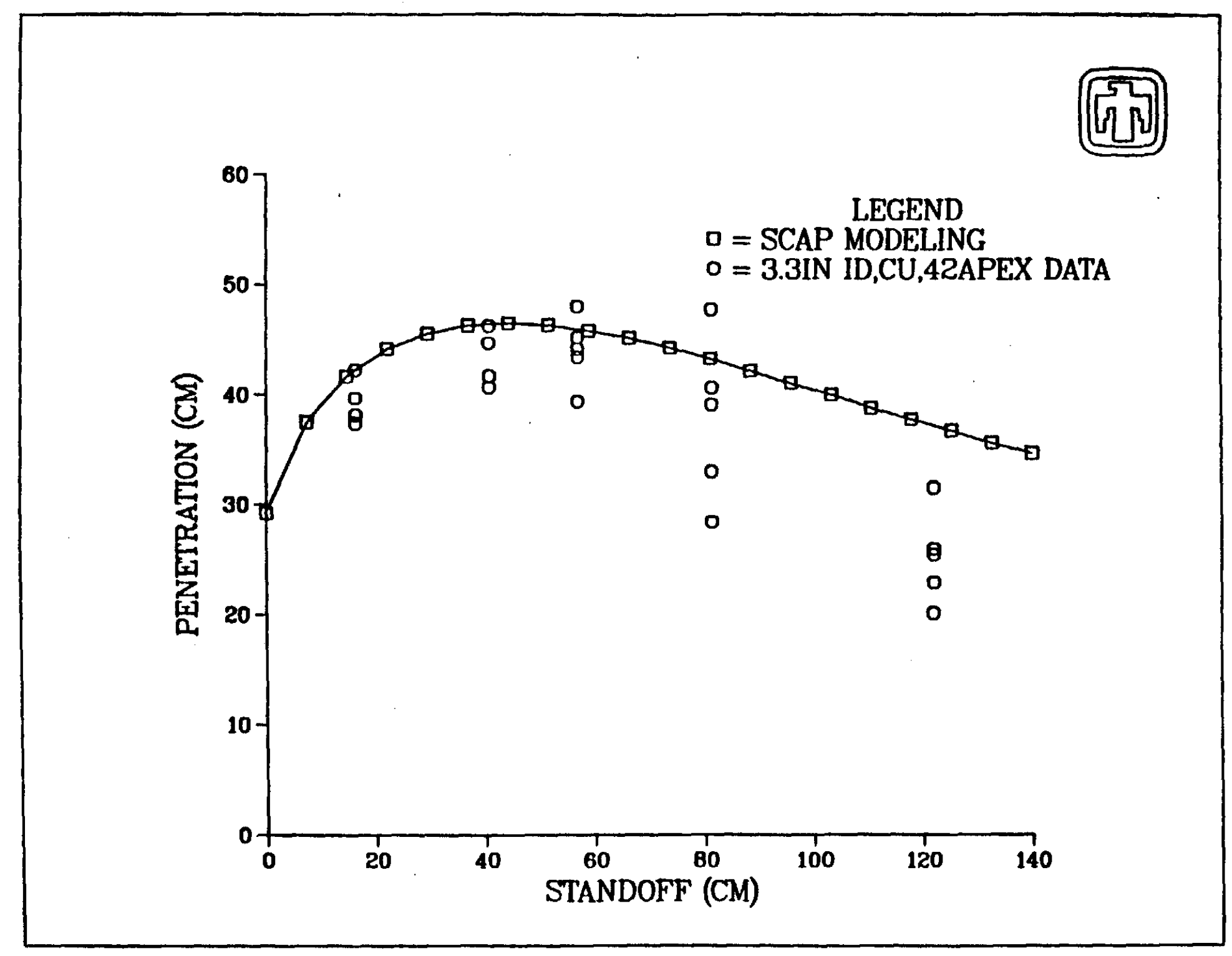




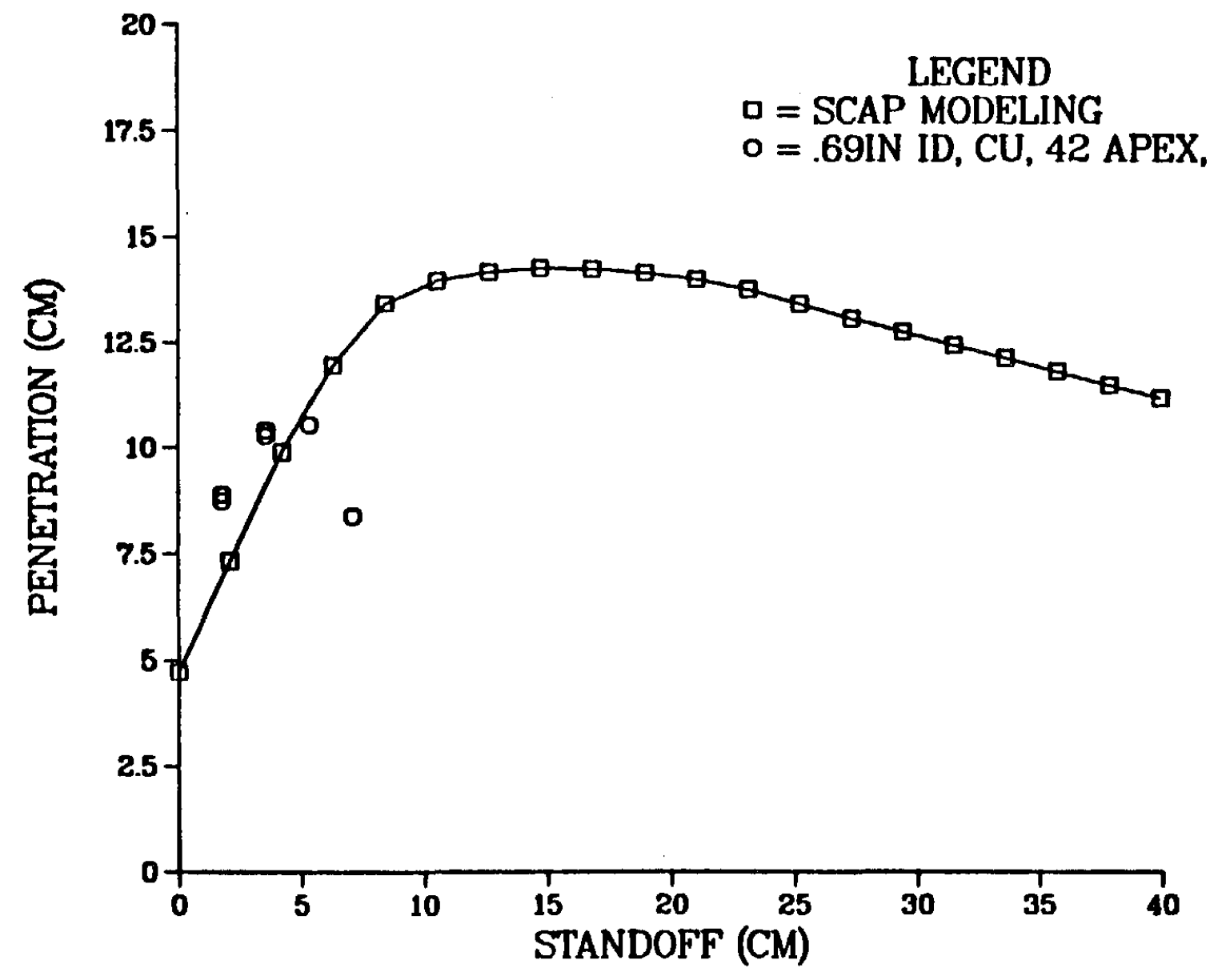

Figure A15. .69 Inch Diameter CSC Jet Penetration Versus Standoff Analytical-Experimental Comparison 


\section{APPENDIX B}

Sample SCAP Code Graphical Output of Selected CSC 


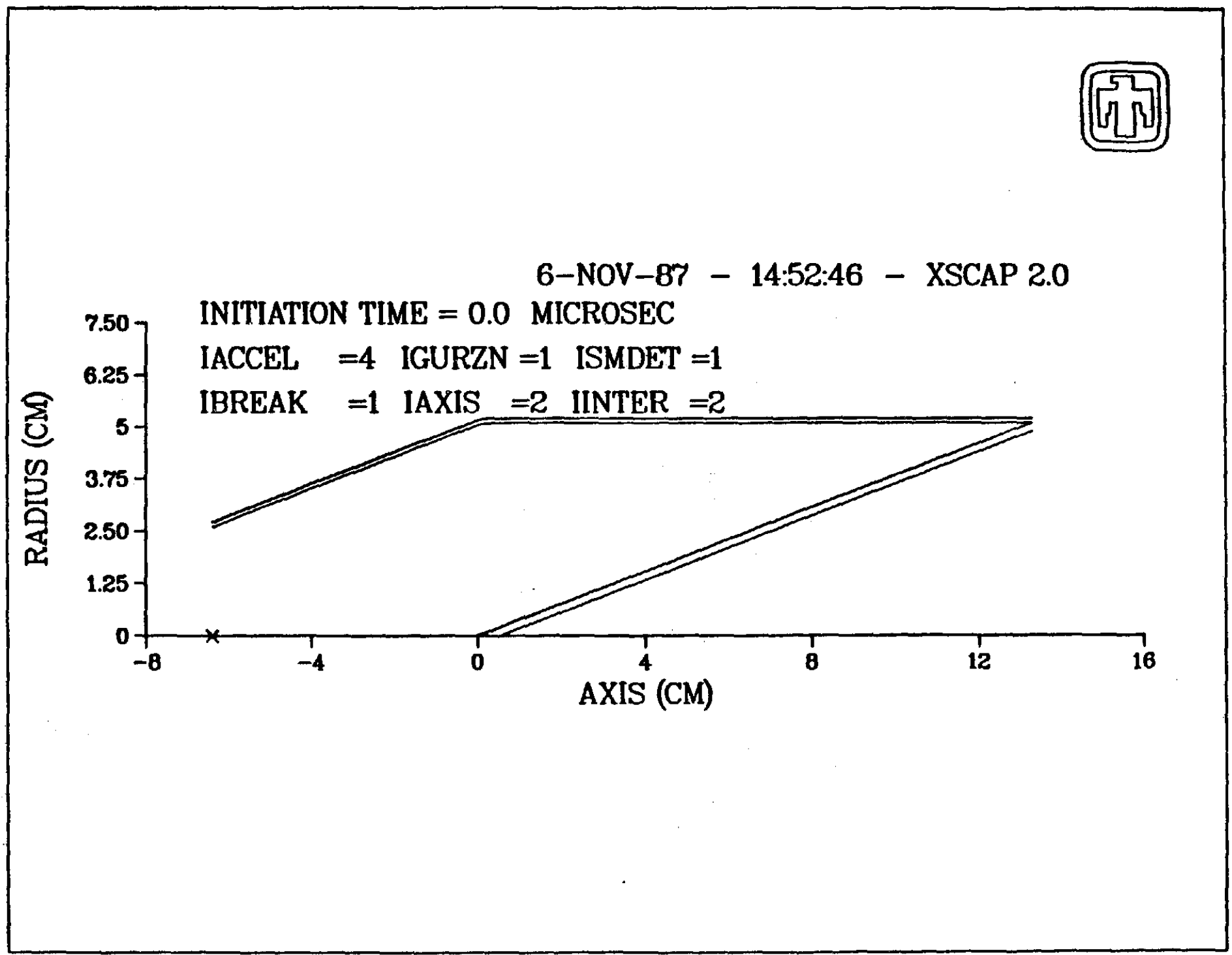

Figure B1. CSC sCAP Code Modeling Cross-Section 


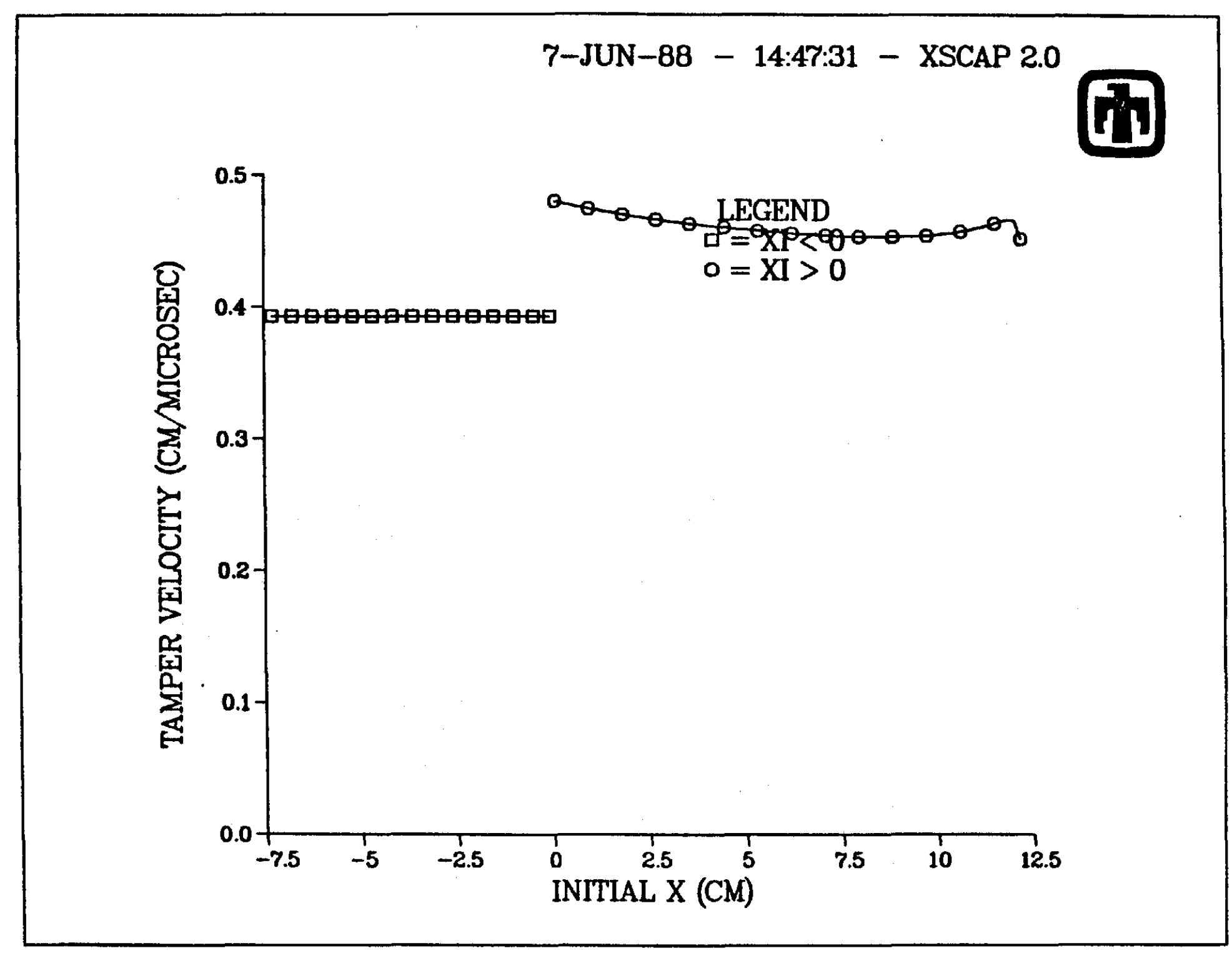




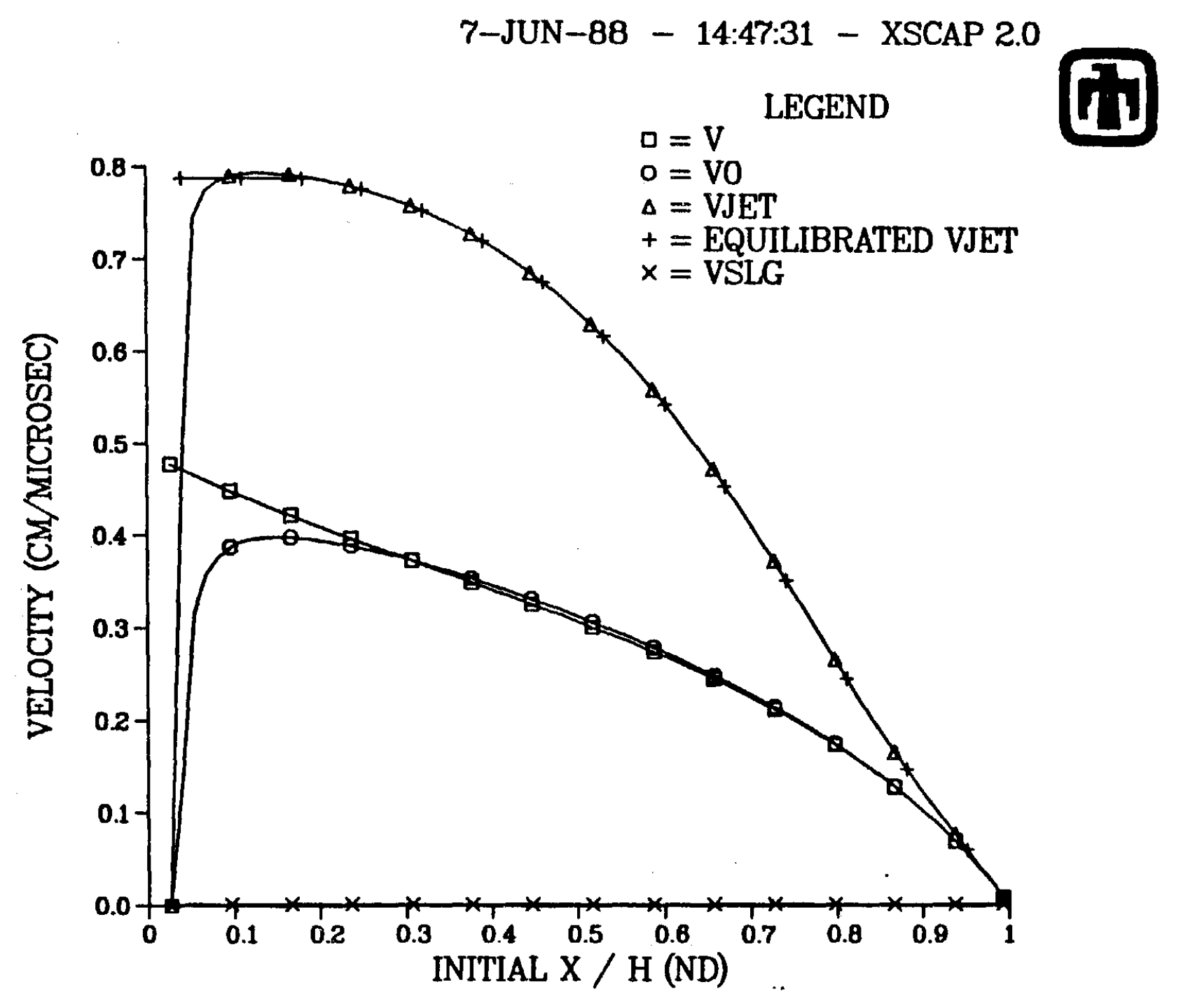

Figure B3. Material Velocities Versus Initial Liner Height Position 


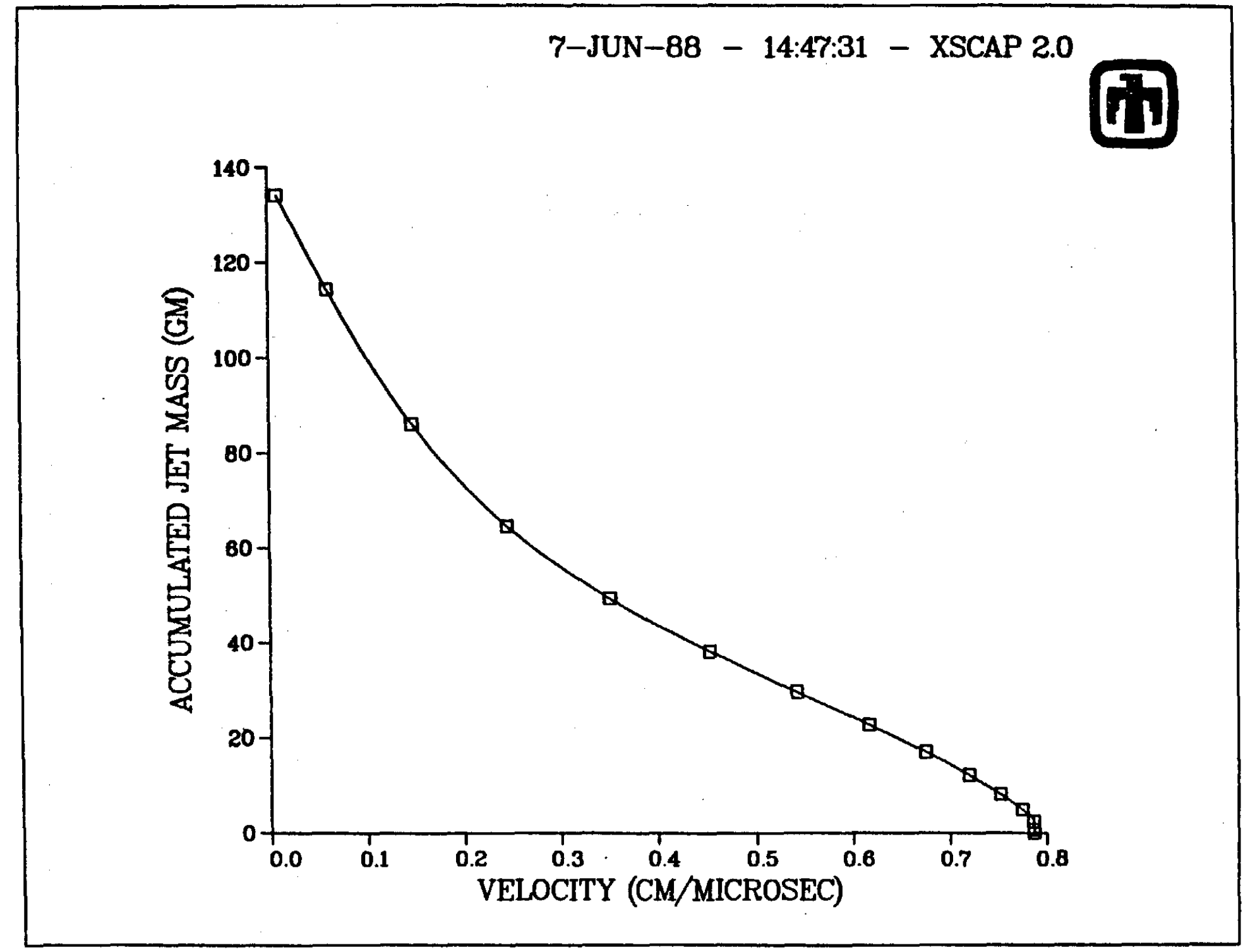




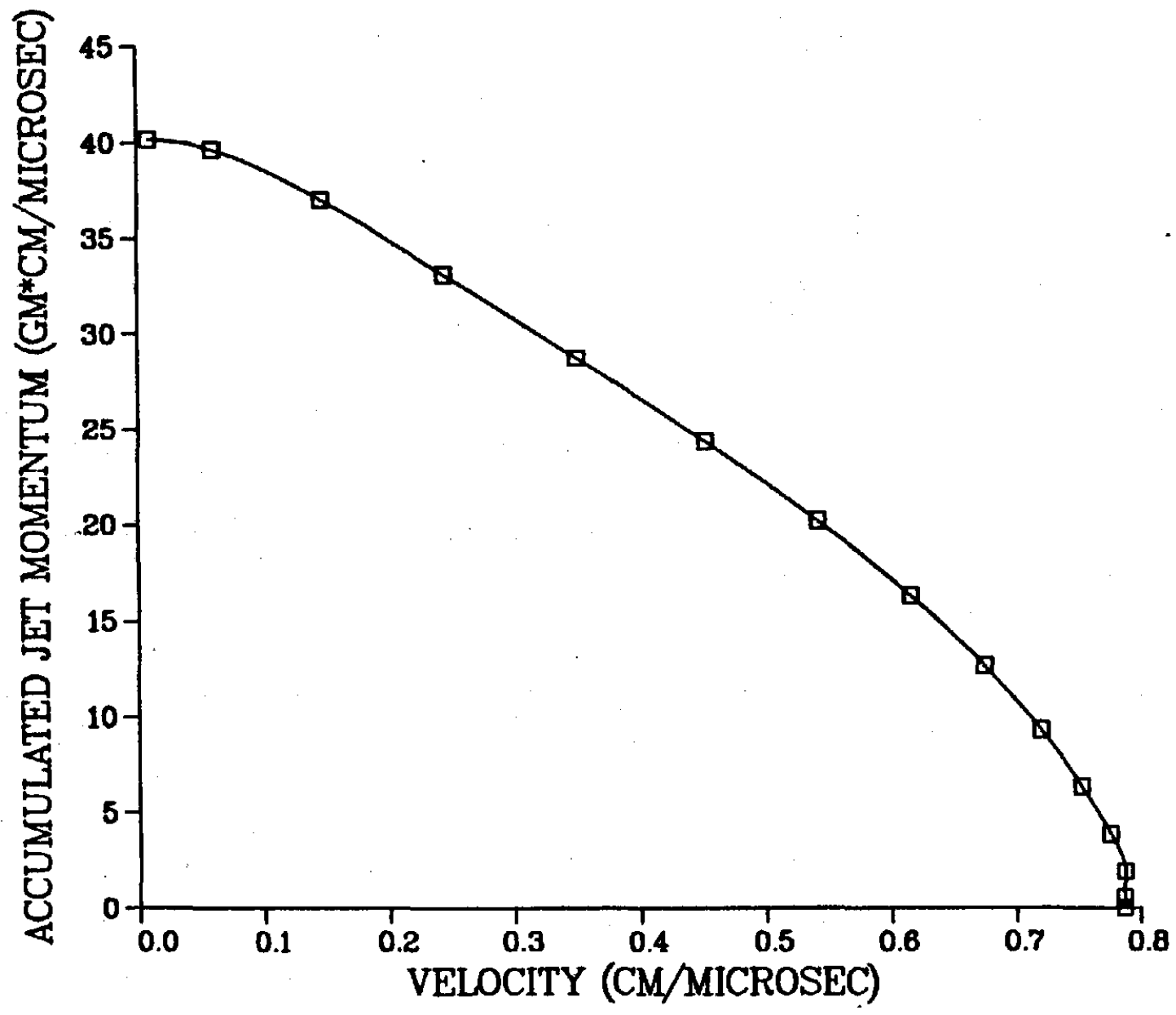

Figure B5. Jet Momentum Versus Jet Velocity 


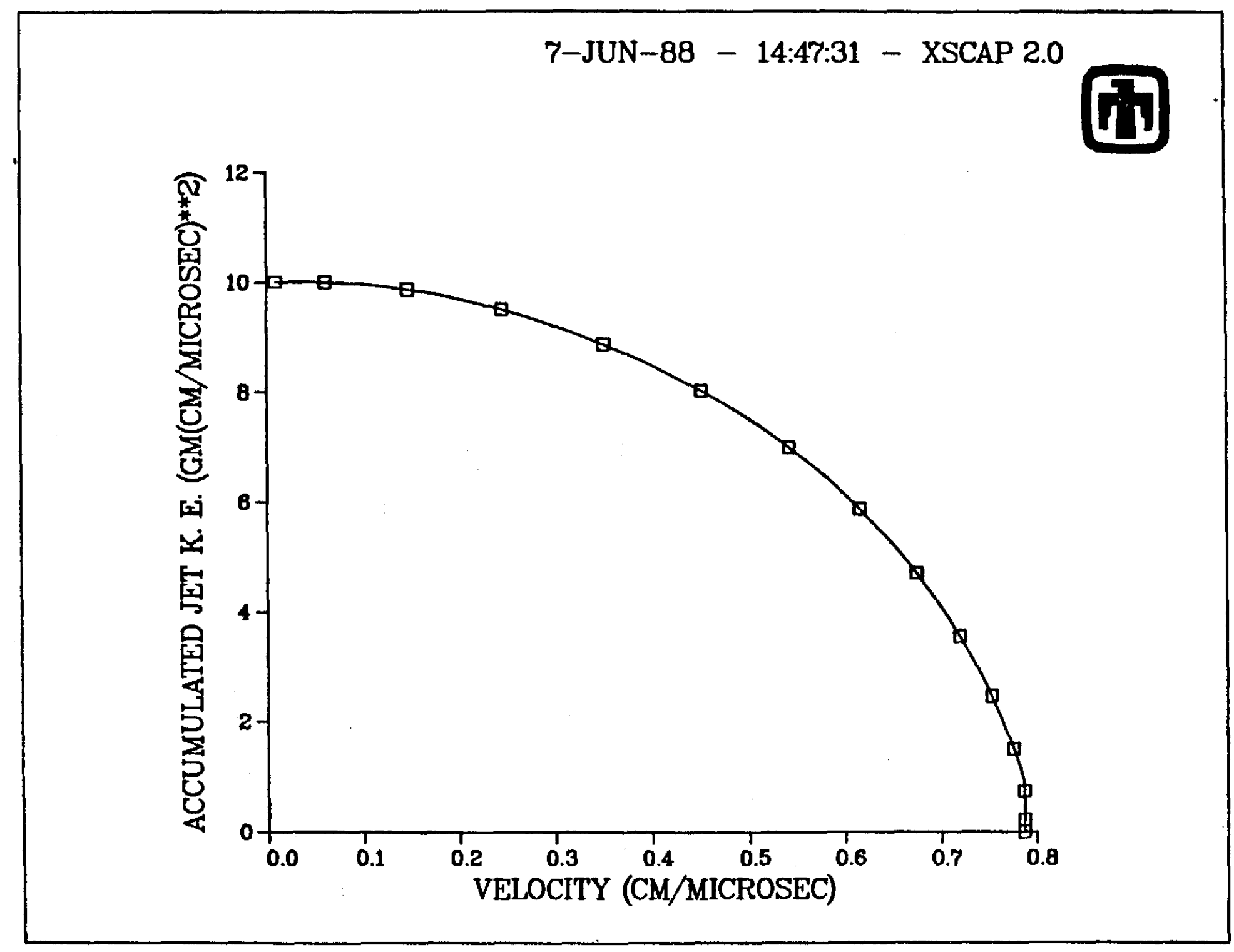




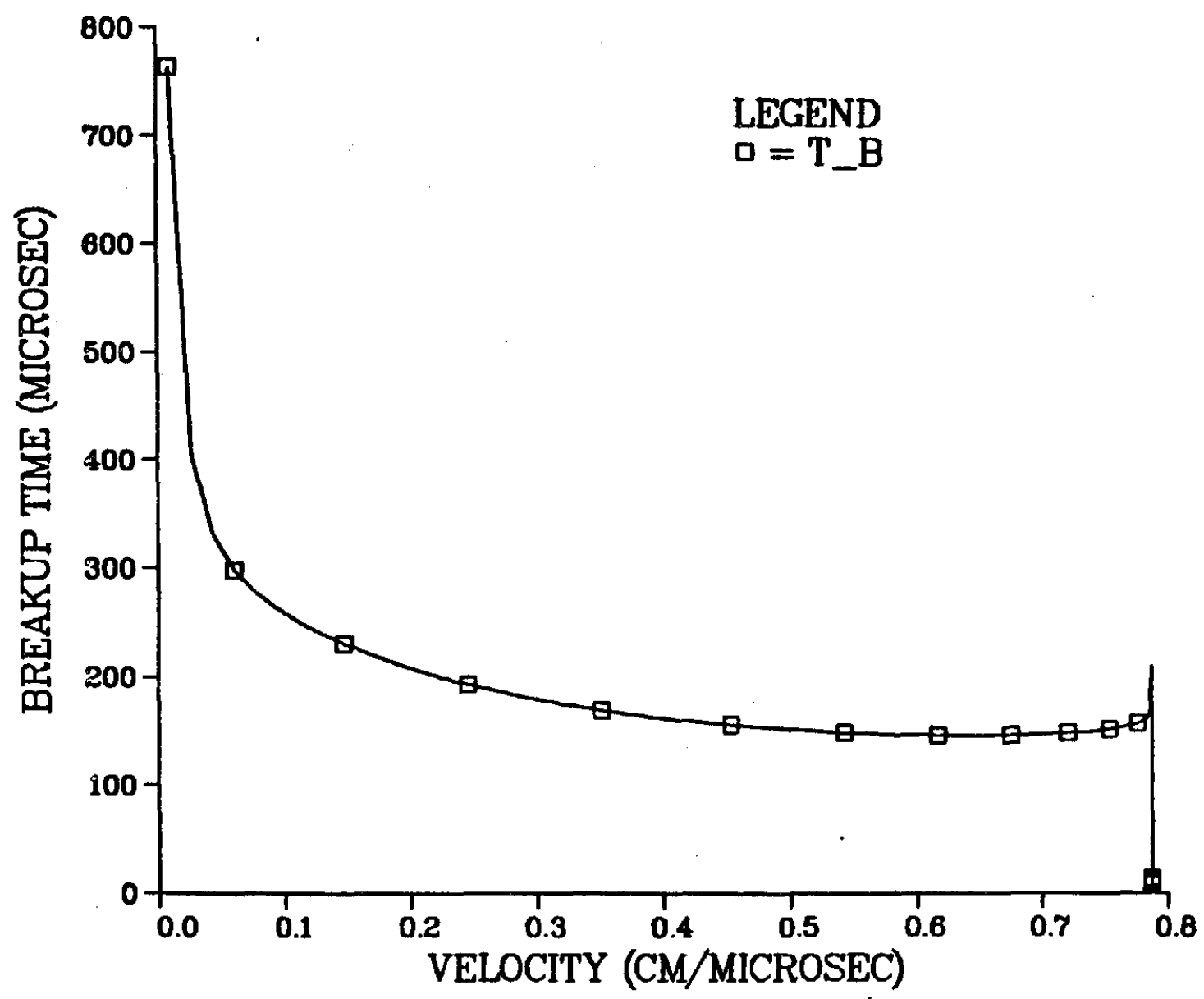

Figure B7. Jet Breakup Time Versus Jet Velocity 


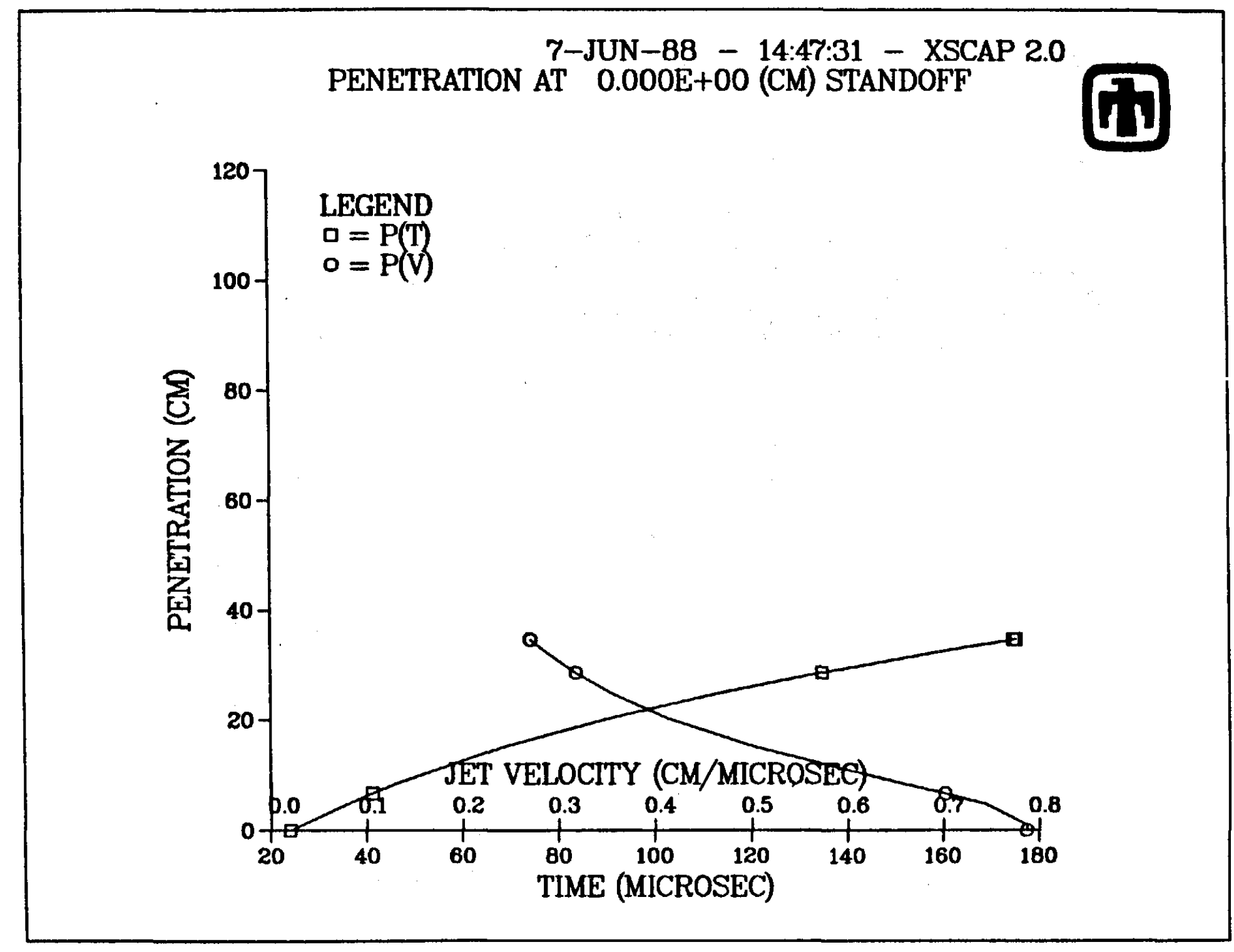




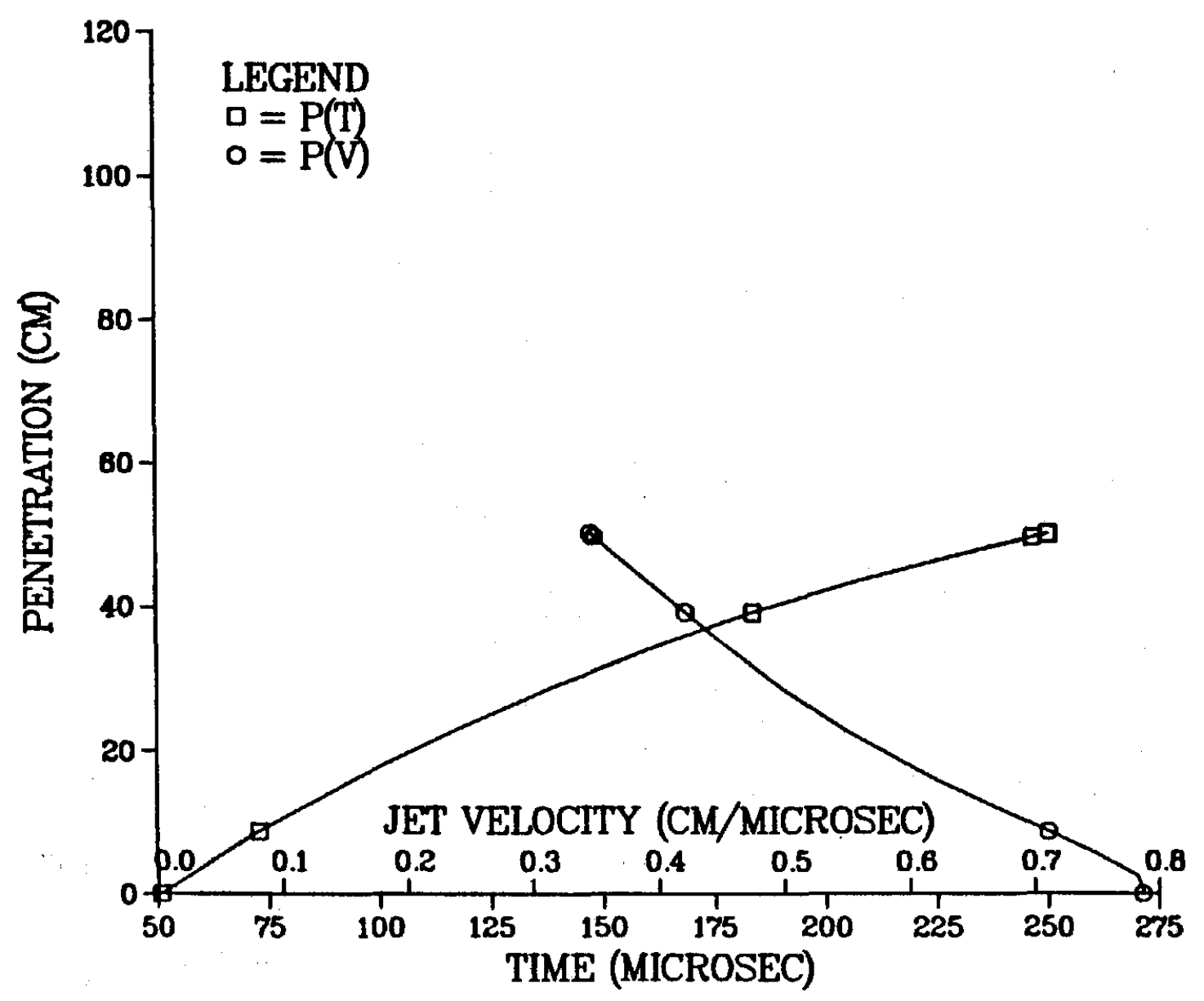

Figure B9. Jet Penetration Versus Time and Velocity at 21.1 CM Standoff 


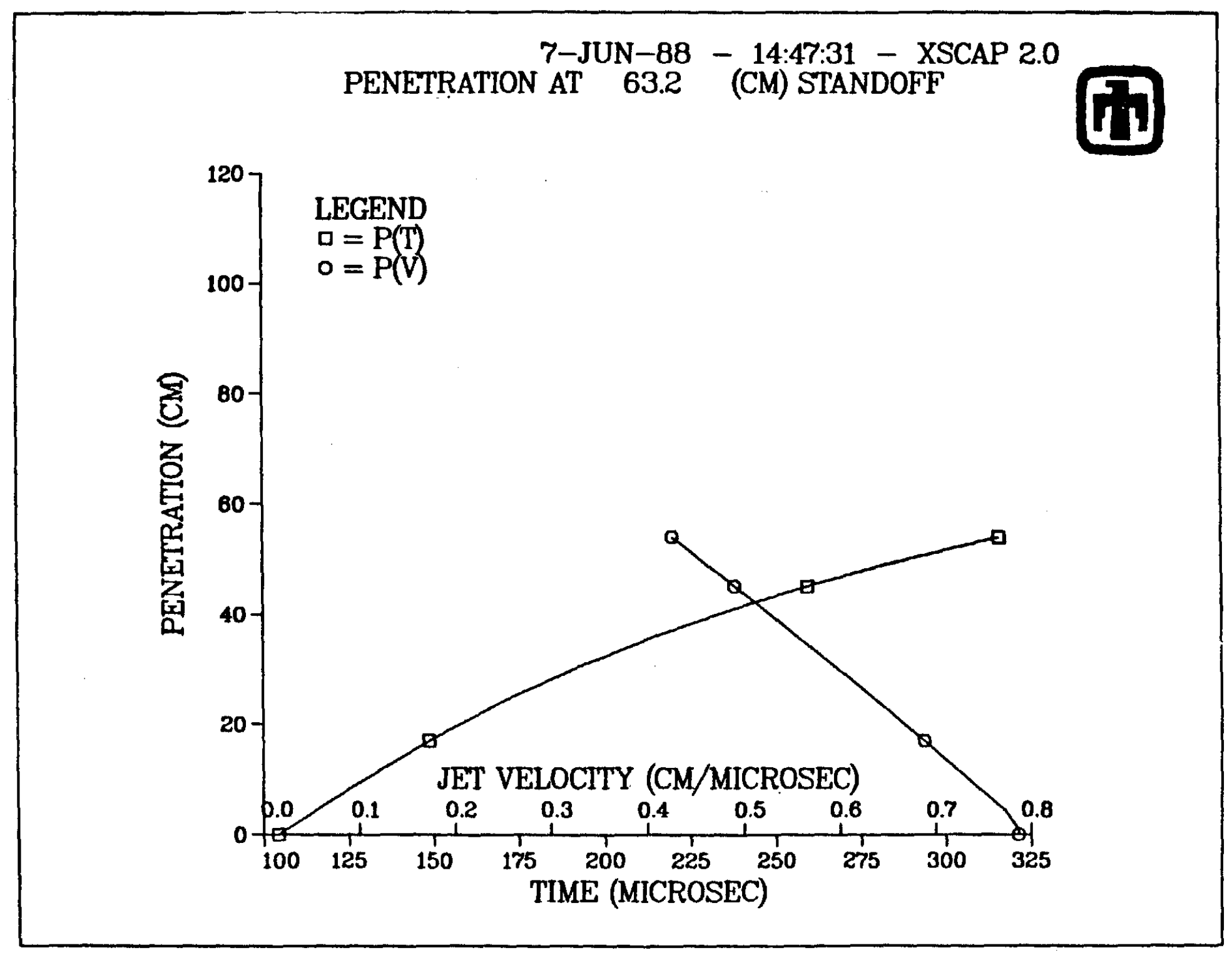

Figure B10. Jet Penetration Versus Time and Velocity at 63.2 CM Standoff 


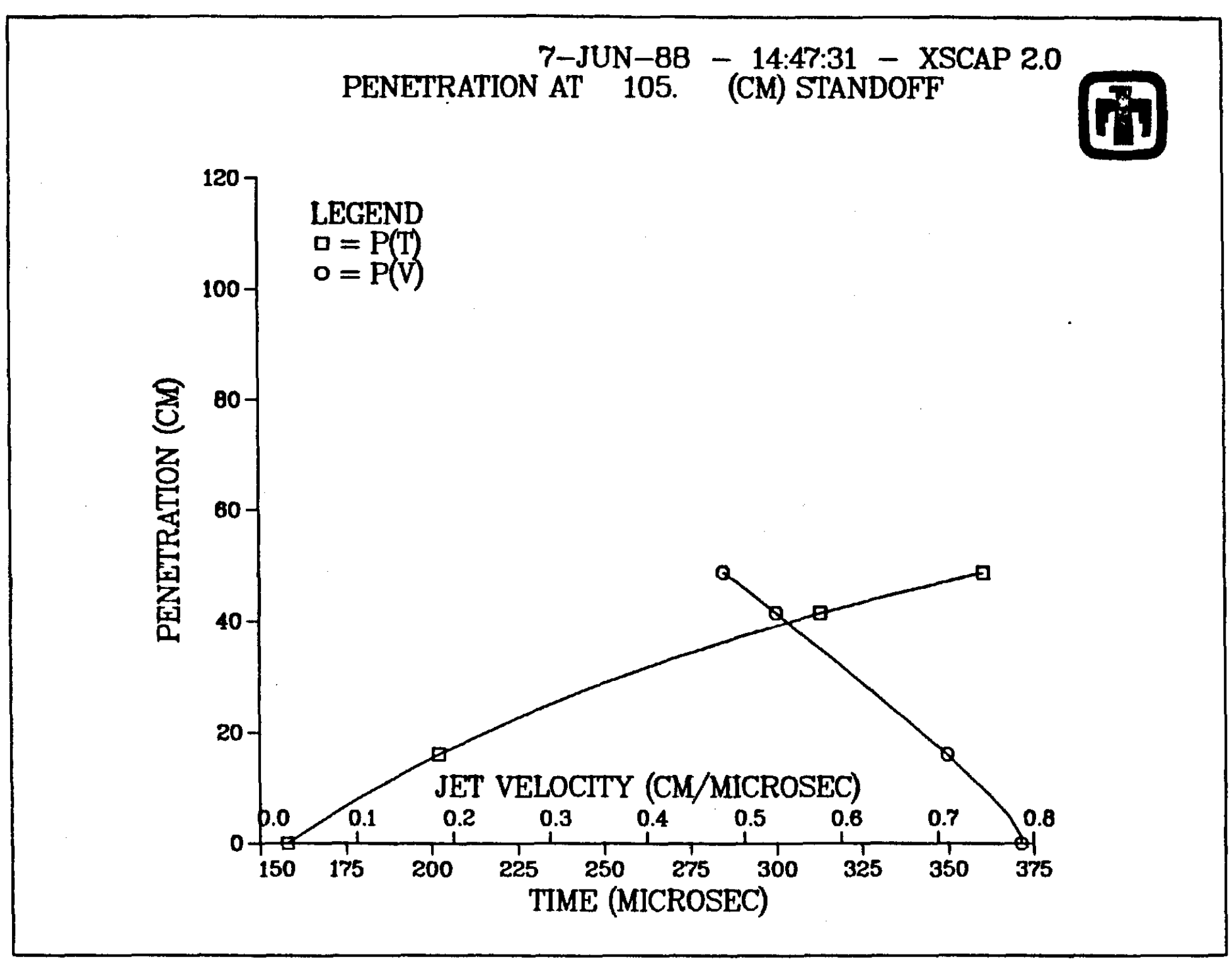

Figure B11. Jet Penetration Versus Time and Velocity at 105 CM Standof 


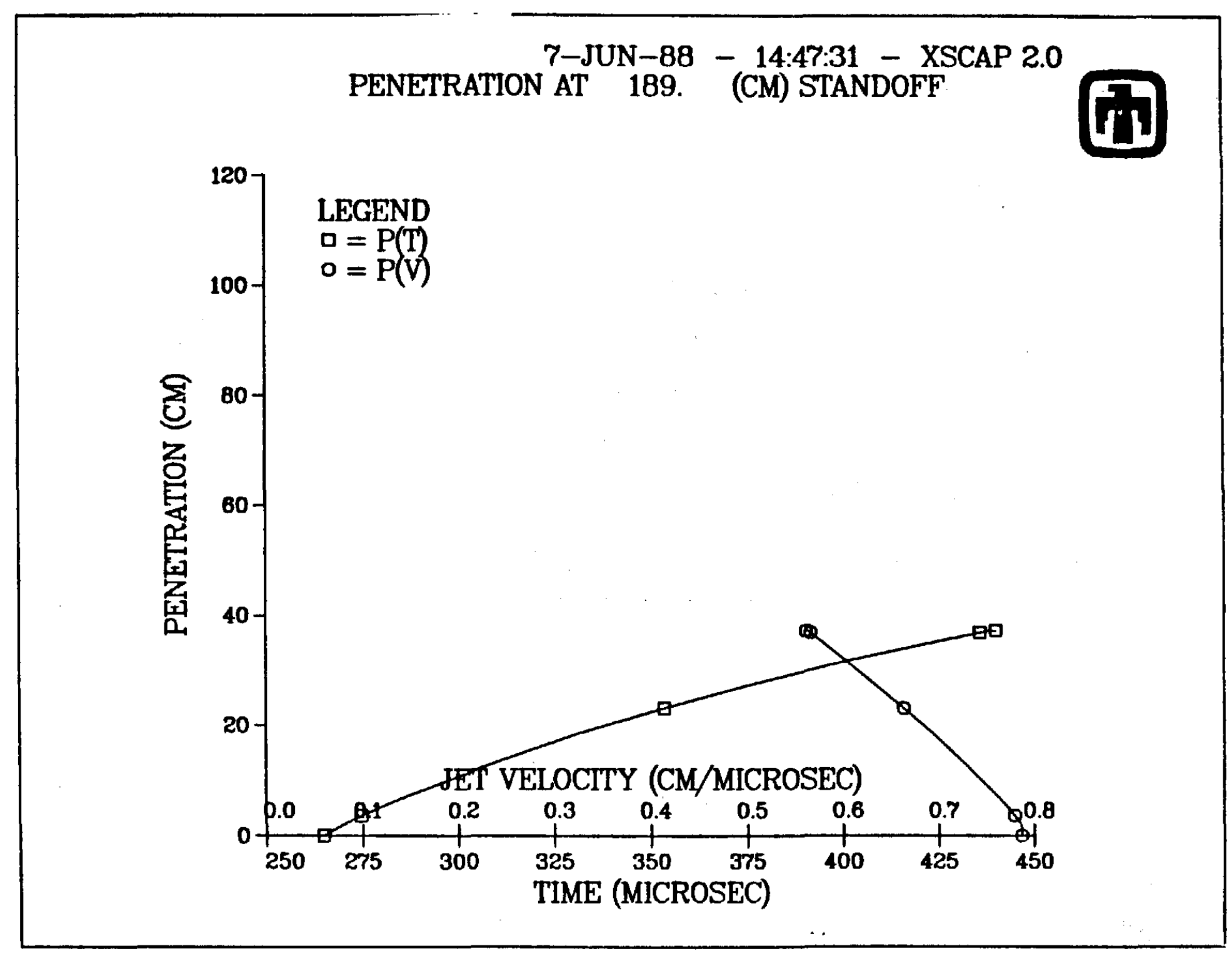




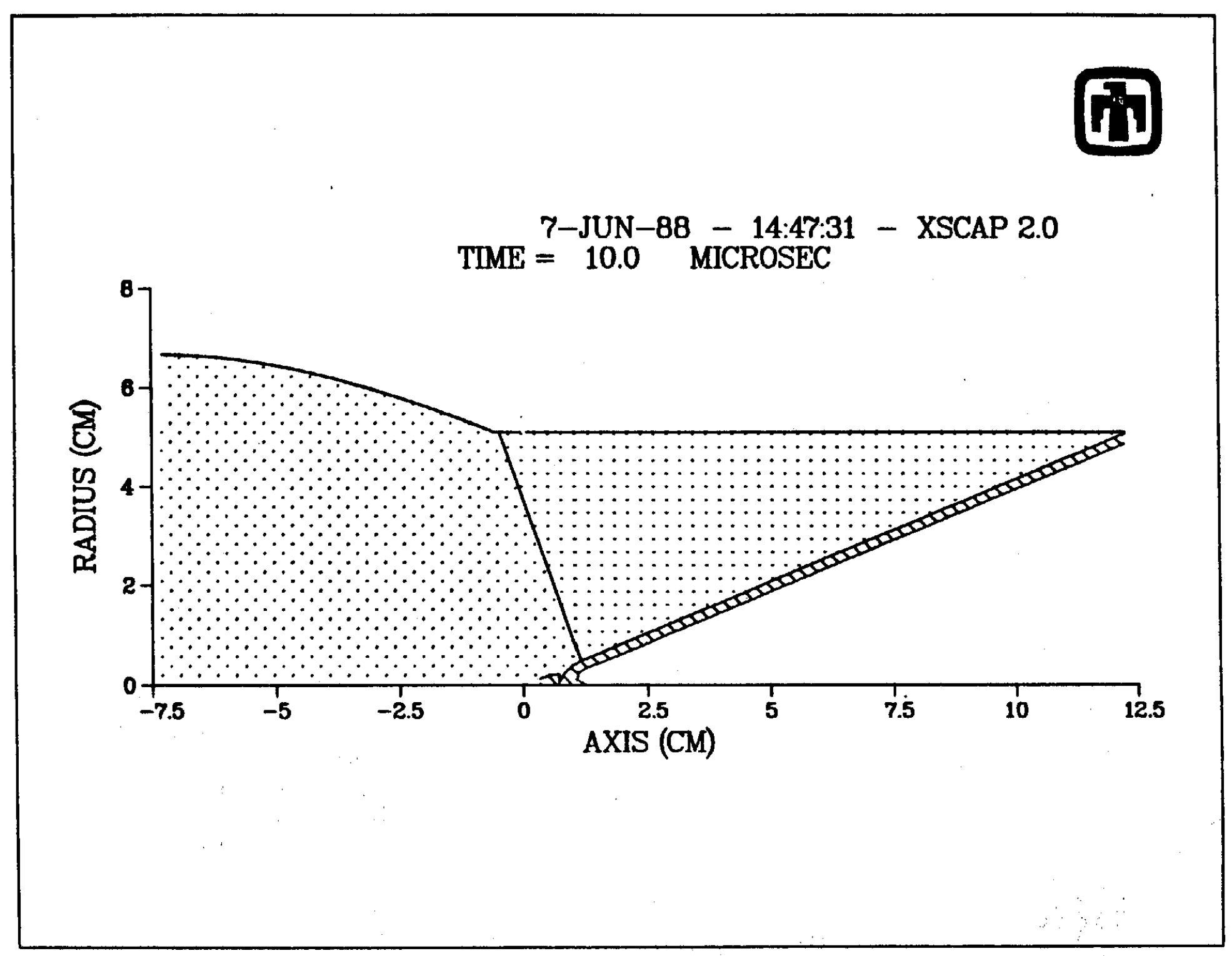

Figure B13. Detonation Wave at Liner Apex 


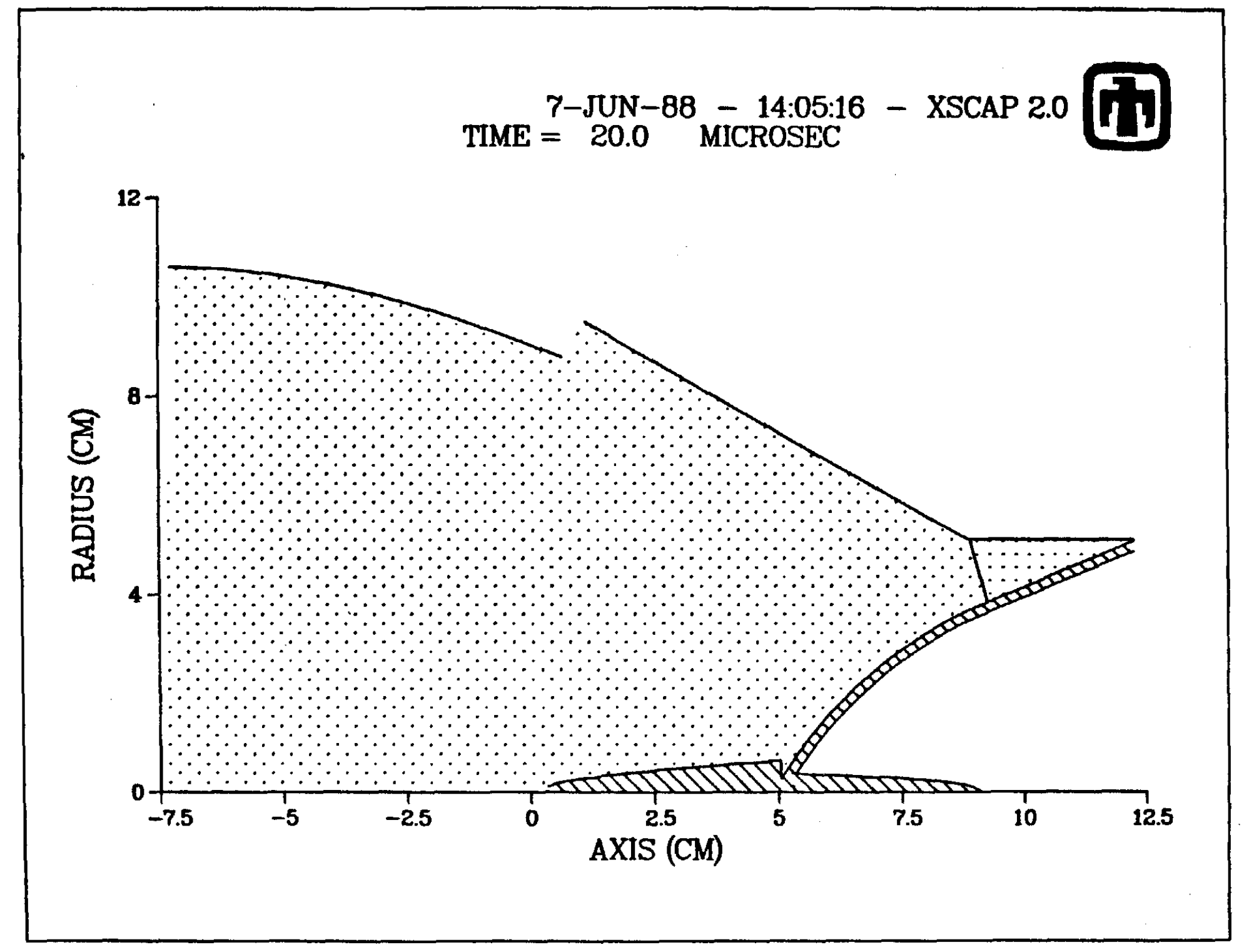




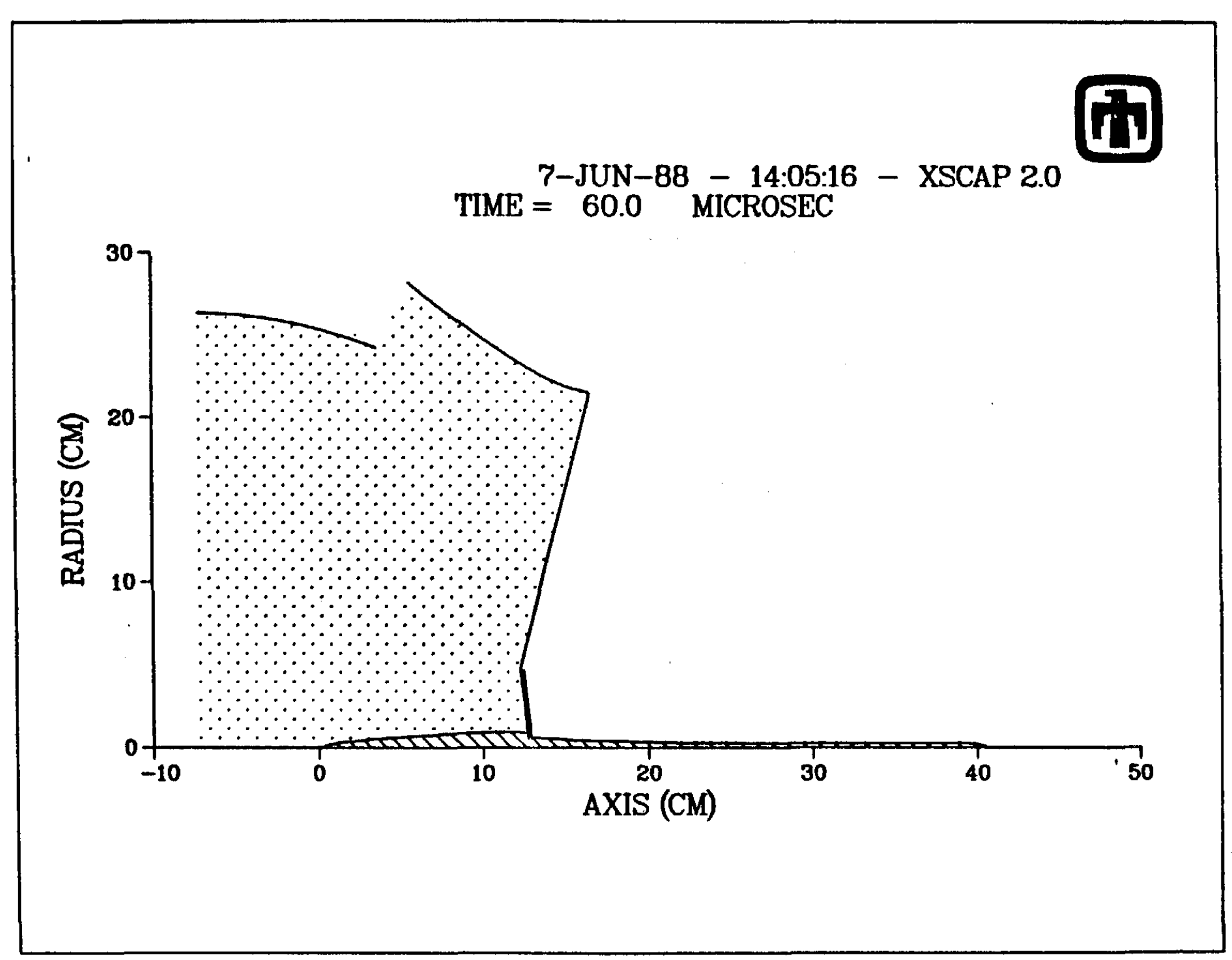

Figure B15. Jet, Slug, Detonation Product Gases at 60 Microseconds 


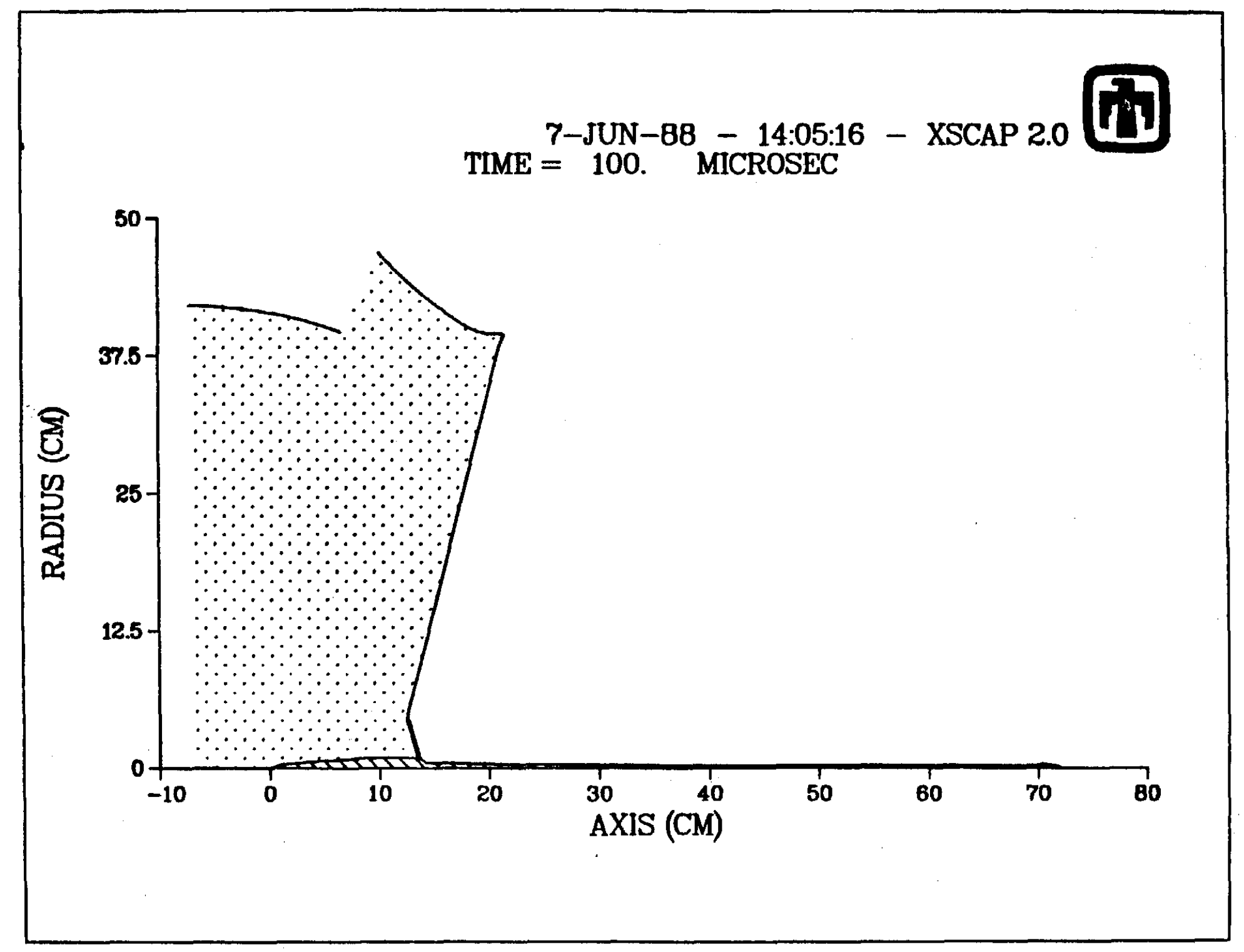




\section{References}

1. A. C. Robinson, SCAP-A Shaped Charge Analysis Program - User's Manual for SCAP 1.0, SAND85-0708, Sandia National Laboratories, Albuquerque, NM, April 1985.

2. A. C. Robinson, Asymptotic Formulas for the Motion of Shaped Charge Liners, SAND84-1712, Sandia Laboratories, Albuquerque, NM, September 1984.

3. A. C. Robinson, Multilayered Liners for Shaped Charge Jets, SAND85-2300,_Sandia National Laboratories, Albuquerque, NM, December 1985.

4. P. C. Chou and W. J. Flis, Recent Developments in Shaped Charge Technology, Propellants, Explosives, Pyrotechhnics, 11, 99-114, 1986.

5. M. G. Vigil, Explosive Initiation by Very Small Conical Shaped Charge Jets, Proceedings of the Eighth International Symposium on Detonation, Albuquerque, NM, July 15-19, 1985.

6. L. I. Sedo, Similarity and Dimensional Methods in Mechanics, Trans. by Morris Friedman, ed., Maurice Hold, NY: Academic Press, 1959.

7. H. L. Langhaar, Dimensional Analysis and Theory of Models, Wiley, NY, 1951

8. W. E. Baker, P. S. Westline, and F. T. Dodge, Similarity Methods in Engineering Dynamics, Hayden Book Co., Inc., Rochelle Park, NJ, 1973.

9. M. G. Vigil, A Scaling Law for the Penetration of Reinforced Concrete Barriers with Tamped Explosive Charges on the Surface, SAND79-1256, Sandia National Laboratories, Albuquerque, NM, August 1979.

10. Bridgman, P. W., Dimensional Analysis, New Haven: Yale University Press, 1931.

11. M. G. Vigil and R. P. Sandoval, Development of a Method for Selection of Scaled Conical Shaped Explosive Charges, SAND80-1770, Sandia National Laboratories, Albuquerque, NM, March 1982.

12. J. E. Kennedy, Gurney Energy of Explosives: Estimation of the Velocity and Impulse Imparted to Driven Metal, Report SC-RR-70-790, Sandia National Laboratories, Albuquerque, NM, December 1970. 


\section{DISTRIBUTION:}

Aerojet Ordnance Co.

Attn: J. Carleone

2521 Michelle

Tustin, CA 92680

Ballistic Research Lab (10)

Aberdeen Proving Ground

Attn:

D. Dietrich

R. J. Eichelberger

F. Grace

J. T. Harrison

R. Jameson

K. Kimsey

M. Lampson

S. B. Segletes

W. P. Walter

S. K. Golaskie

Aberdeen, MD 21005

Joseph Backofen

P. O. Box 1925

Washington, DC 20013

Battelle Columbus Laboratory (2)

Attn: J. White

D. R. Trott

505 King Avenue

Columbus, $\mathrm{OH} 43201$

Ctr for Explosives Tech. Research

New Mexico Technical Institute

Attn: Per-Anders Persson

Socorro, NM 87801

Dyna East Corp (3)

Attn: P. C. Chou

R. C. Ciccarelli

W. J. Flis

3132 Market Street

Philadelphia, PA 19104
Honeywell, Inc. (3)

Defense Systems Division

Attn: J. Houlton

G. R. Johnson

L. T. Pfeiffer

5901 South County Road 18

Edina, MN 55436

Lawrence Livermore National Lab (6)

Attn: $\quad$ M. Finger

J. D. Immele

J. L. Levatin

M. J. Murphy

M. Van Thiel

P. O. Box 808

M. L. Wilkins

Livermore, CA 94550

Los Alamos National Lab (12)

Attn: J. D. Allen, G787

R. Carver, B265

E. H. Farnum, G756

M. Ginsberg, J960

L. W. Hantel, F668

J. Hopson, F664

R. Karpp, P940

J. Repa, J960

P. Studt, F668

R. J. Yount, F664

J. Walsh

P. O. Box 1663

R. McCormick

Los Alamos, NM 87545

Naval Weapons Center

Materials Eng. Branch

Attn: G. A. Hayes

China Lake, CA 93555 
Teledyne (3)

Attn: B. Heideman

D. F. Elliott

W. B. Richardson

3601 Union Road

Hollister, CA 95023

U.S. Army Armament Research and Development Center

Attn: A. Garcia

Building 354

Dover, NJ 07801

E. I. DuPont de Nemours \& Co, Inc.

Attn: F. C. Sawyers

3520 Pebble Beach Dr

Farmers Branch, TX 75234

Explosive Technology (2)

Attn: M. D. Anderson

P. O. Box KK

J. E. Kennedy

Fairfield, CA 94533-0659

Mason \& Hanger (6)

Silas Mason Co., Inc

Pantex Plant

Attn: D. Garrett

R. Slape

D. Hilleary

D. Schaffer

P. Kramer

P. O. Box 30020

C. A. Campos

Amarillo, TX 79177

Allied-Signal Aerospace Co

Kansas City Div.

Attn: G. Oswald

P. O. Box 1159

Kansas City, MO 64141
Unidynamics/Phoenix, Inc. (2)

Attn: R. Smith

J. Fronabarger

P. O. Box 2990

Phoenix, AZ 85062

Ensign-Bickford Co (4)

Aerospace Division

Attn: L. Mecca

B. Boggs

K. Puls

E. Tarca

660 Hopmeadow St.

Simsbury, CT 06070

Jet Research Center, Inc.

P. O. Box 246

Arlington, TX 76010

Lockheed Missiles \& Space Co (5)

Attn: W. E. Moffatt

R. Weinheimer

J. Meeks

J. P. Beck

N. Markovich-Cottong

1111 Lockheed Way

Sunnyvale, CA 94086

Southwest Research Institute

Attn: A. B. Wenzel

6220 Culebra Road

PO Drawer 28510

San Antonio, TX 78284

Strategic Systems Project Office Department of the Navy

Attn: D. Kenemuth, 27314

Washington, DC 20376 
Distribution:

\begin{tabular}{|c|c|c|c|}
\hline 1131 & B. Morosin & $3154-1$ & C. H. Dalin (8) \\
\hline $\begin{array}{l}1413 \\
1500\end{array}$ & $\begin{array}{l}\text { G. G. Weigand } \\
\text { W. Herrmann }\end{array}$ & 5120 & $\begin{array}{l}\text { For DOE/OSTI } \\
\text { W R Revnolds }\end{array}$ \\
\hline 1510 & J. W. Nunziato & 5121 & D. F. McVey \\
\hline 1512 & J. C. Cummings & 5121 & O. R. Berg \\
\hline 1513 & D. W. Larsen & 5121 & D. L. DeWerff \\
\hline 1521 & R. D. Krieg & 5121 & M. M. Plugge \\
\hline 1522 & R. C. Reuter & 5128 & B. E. Bader \\
\hline 1523 & J. H. Biffle & 5128 & K. E. Mead \\
\hline 1524 & D. B. Longscope & 5165 & S. D. Meyer \\
\hline 1530 & L. W. Davison & 5165 & R. K. Thomas \\
\hline 1531 & S. L. Thompson & 5165 & N. R. Hansen \\
\hline 1531 & T. K. Bergstresser & 5165 & W. J. Errickson \\
\hline 1531 & S. L. Passman & 5165 & W. J. Patterson \\
\hline 1531 & J. W. Swegle & 5165 & L. B. Traylor \\
\hline 1533 & P. Yarrington & 5251 & T. A. Sellers, Actg \\
\hline 1533 & M. E. Kipp & 5251 & L. A. Suber \\
\hline 1533 & A. C. Robinson & 5262 & J. W. Kane \\
\hline 1534 & J. R. Asay & 6230 & W. C. Luth \\
\hline 1534 & D. E. Grady & 6320 & J. E. Stiegler \\
\hline 1534 & T. G. Trucano & 6321 & R. E. Luna \\
\hline 1534 & J. L. Wise & 6321 & R. P. Sandoval \\
\hline 2500 & D. B. Hayes, Actg & 6322 & J. M. Freedman \\
\hline 2510 & D. H. Anderson & 6323 & G. C. Allen \\
\hline 2512 & J. G. Harlan & 6323 & H. R. Yoshimura \\
\hline 2512 & D. R. Begeal & 6400 & D. J. McCloskey \\
\hline 2512 & S. G. Hallett & 6416 & R. M. Cranwell \\
\hline 2512 & R. G. Jungst. & 6416 & E. L. Emerson \\
\hline 2512 & D. L. Marchi & 6416 & J. S. Philbin \\
\hline 2512 & M. G. Vigil (15) & 7130 & J. D. Kennedy \\
\hline 251 & D. E. Mitchell & 7133 & O. L. Burchett \\
\hline 251 & S. G. Barnhart & 7133 & P. W. Cooper \\
\hline & T. L. Garcia & 7133 & S. R. Kurowski \\
\hline & P. L. Stanton & 7170 & R. D. Bentley \\
\hline & L. L.Bonzon & 7173 & G. L. West \\
\hline & P.D. Wilcox & 7173 & H. D. Smith \\
\hline & M. R. Kopczewski & 7533 & F. H. Mathews \\
\hline & W. N. Sullivan & 7533 & J.P. Weber \\
\hline & L. D. Bertholf & 7535 & D. C. Bickel \\
\hline & S. A. Landenberger (5) & 8524 & P. W. Dean \\
\hline & W. I. Klein (3) & & \\
\hline
\end{tabular}

